\title{
Article \\ Ruthenium Half-Sandwich Type Complexes with Bidentate Monosaccharide Ligands Show Antineoplastic Activity in Ovarian Cancer Cell Models through Reactive Oxygen Species Production
}

\author{
István Kacsir ${ }^{1,2,+}{ }^{\text {, Adrienn Sipos }}{ }^{3,+}{ }^{\text {, Gyula Ujlaki }}{ }^{3}$, Péter Buglyó ${ }^{4} \mathbb{D}$, László Somsák ${ }^{1} \mathbb{D}$, Péter Bai $^{3,5,6, *(\mathbb{D})}$ \\ and Éva Bokor 1 ,*
}

\section{check for} updates

Citation: Kacsir, I.; Sipos, A.; Ujlaki, G.; Buglyó, P.; Somsák, L.; Bai, P.; Bokor, É. Ruthenium Half-Sandwich Type Complexes with Bidentate Monosaccharide Ligands Show Antineoplastic Activity in Ovarian Cancer Cell Models through Reactive Oxygen Species Production. Int. J. Mol. Sci. 2021, 22, 10454. https:// doi.org/10.3390/ijms221910454

Academic Editor: Evgeny Imyanitov

Received: 1 June 2021

Accepted: 23 September 2021

Published: 28 September 2021

Publisher's Note: MDPI stays neutral with regard to jurisdictional claims in published maps and institutional affiliations.

Copyright: (c) 2021 by the authors. Licensee MDPI, Basel, Switzerland. This article is an open access article distributed under the terms and conditions of the Creative Commons Attribution (CC BY) license (https:// creativecommons.org/licenses/by/ $4.0 /)$.
1 Department of Organic Chemistry, University of Debrecen, P.O. Box 400, H-4002 Debrecen, Hungary; kacsir.istvan@science.unideb.hu (I.K.); somsak.laszlo@science.unideb.hu (L.S.)

2 Doctoral School of Chemistry, University of Debrecen, P.O. Box 400, H-4002 Debrecen, Hungary

3 Department of Medical Chemistry, Faculty of Medicine, University of Debrecen, H-4032 Debrecen, Hungary; siposadri@med.unideb.hu (A.S.); ujlaki.gyula@med.unideb.hu (G.U.)

4 Department of Inorganic \& Analytical Chemistry, Faculty of Sciences and Technology, University of Debrecen, H-4032 Debrecen, Hungary; buglyo@science.unideb.hu

5 NKFIH-DE Lendület Laboratory of Cellular Metabolism, H-4032 Debrecen, Hungary

6 Research Center for Molecular Medicine, Faculty of Medicine, University of Debrecen, H-4032 Debrecen, Hungary

* Correspondence: baip@med.unideb.hu (P.B.); bokor.eva@science.unideb.hu (É.B.)

+ Equal contribution.

Abstract: Ruthenium complexes are developed as substitutes for platinum complexes to be used in the chemotherapy of hematological and gynecological malignancies, such as ovarian cancer. We synthesized and screened 14 ruthenium half-sandwich complexes with bidentate monosaccharide ligands in ovarian cancer cell models. Four complexes were cytostatic, but not cytotoxic on A2780 and ID8 cells. The $\mathrm{IC}_{50}$ values were in the low micromolar range (the best being $0.87 \mu \mathrm{M}$ ) and were similar to or lower than those of the clinically available platinum complexes. The active complexes were cytostatic in cell models of glioblastoma, breast cancer, and pancreatic adenocarcinoma, while they were not cytostatic on non-transformed human skin fibroblasts. The bioactive ruthenium complexes showed cooperative binding to yet unidentified cellular target(s), and their activity was dependent on reactive oxygen species production. Large hydrophobic protective groups on the hydroxyl groups of the sugar moiety were needed for biological activity. The cytostatic activity of the ruthenium complexes was dependent on reactive species production. Rucaparib, a PARP inhibitor, potentiated the effects of ruthenium complexes.

Keywords: ovarian cancer; ruthenium complex; half-sandwich; cooperative binding; reactive oxygen species production; glycosyl heterocycle; oxadiazole; triazole; rucaparib

\section{Introduction}

Metal-based drugs used in cancer therapy include square planar platinum(II) complexes, e.g., cisplatin (Figure 1, I), oxaliplatin (II), and carboplatin (III), which are registered worldwide. Although Pt complexes are versatile tools of the trade, their applicability has shortcomings, such as the development of platinum resistance in tumors [1,2], ototoxicity [3], and nephrotoxicity [4,5], with the latter two being very characteristic for cisplatin.

Ruthenium complexes can be promising alternatives to platinum complexes due to their similar chemical characteristics in terms of ligand exchange [6]. In addition, Rucomplexes have enhanced delivery properties compared to $\mathrm{Pt}$-based drugs. For example, Ru-based drugs have improved cellular entry under hypoxic conditions that characterize aggressively growing tumors $[7,8]$, or they can be delivered by binding to transferrin [6]. 
Importantly, multiple studies have pointed out reduced toxicity for Ru-complexes as compared to Pt complexes in both cellular and animal models [9-12]. Both Pt- and Ru-based drugs can be targeted to enzymes or cellular compartments by coupling bait molecules such as biotin, nonsteroidal anti-inflammatory drugs, hormones, or carbohydrates to enhance their chemotherapeutic potential (thoroughly reviewed in [6]).

$$
\mathrm{Cl}^{-} \mathrm{Pt}^{-} \cdot \mathrm{NH}_{3}
$$

I (Cisplatin)

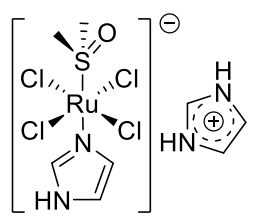

IV (NAMI-A)

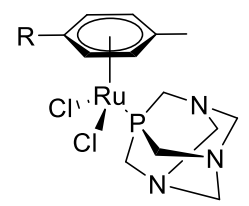

VI (RAPTA-T, $\mathrm{R}=\mathrm{H}$; RAPTA-C, $\mathrm{R}=\mathrm{iPr}$ )

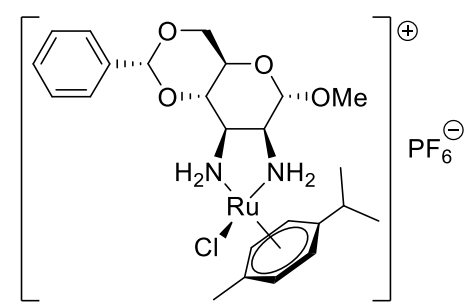

IX

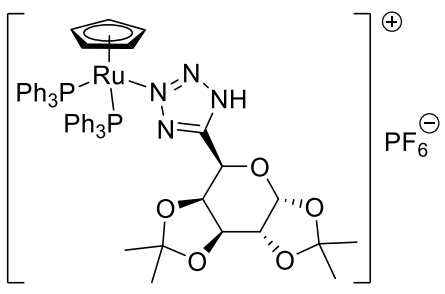

XI

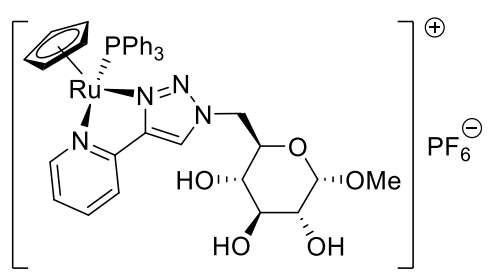

XIII<smiles>O=C1O[PH]2(N[C@H]3CCCC[C@H]3N2)OC1=O</smiles>

II (Oxaliplatin)<smiles>N[PH]1(N)OC(=O)C2(CCC2)C(=O)O1</smiles>

III (Carboplatin)<smiles></smiles>

V (NKP1339)

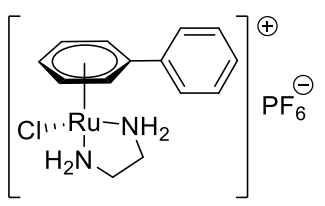

VII (RM175)

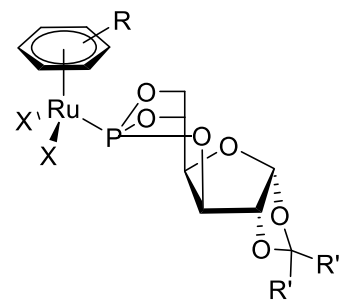

VIII $\left(\mathrm{X}=\mathrm{Hlg},\left(\mathrm{CH}_{2}\right)_{\mathrm{n}}(\mathrm{COO})_{2}\right)$

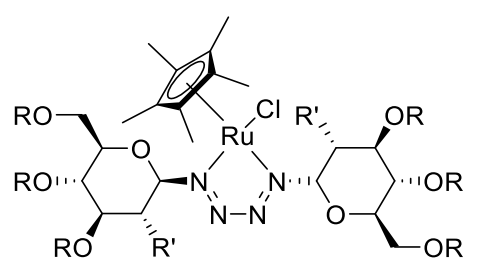

X $\left(\mathrm{R}=\mathrm{H}\right.$, acetyl, propionyl, butyryl; $\left.\mathrm{R}^{\prime}=\mathrm{OR}, \mathrm{NHAc}\right)$

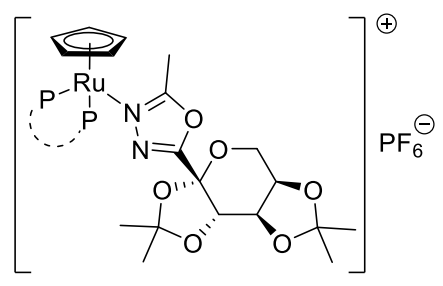

XII
Target compounds of this study Het $^{1}=1,2,3$-triazole,
1,3,4-oxadiazole
Het $^{2}=$ pyridine, quinoline

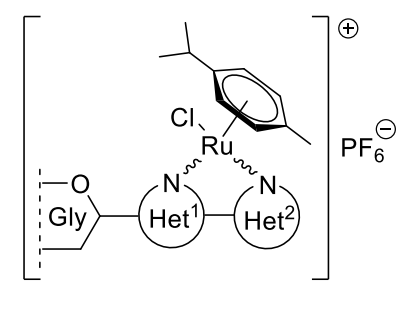

XIV

Figure 1. Selected platinum anticancer drugs and ruthenium complexes with proven anticancer potential. 
Among the $\mathrm{Ru}(\mathrm{III})$ - and $\mathrm{Ru}(\mathrm{II})$-based complexes, a great number of derivatives have been tested as anticancer metallodrugs, and two of them, the imidazolium salt of tetrachlorido(dimethylsulfoxide)(imidazole)ruthenium(III) (Figure 1, IV) and sodium tetrachloridobis(indazole)ruthenium(III) $(\mathbf{V})$, reached clinical trials $[6,13-16]$. The half-sandwich type $\mathrm{Ru}(\mathrm{II})$-arene organometallics [17], due to a high structural variability, represent one of the most widely investigated compound classes in the development of new candidates of multitargeted metallodrugs $[6,18]$. The presence of an $\eta^{6}$-arene or $\eta^{5}$-arenyl residue in the coordination sphere contributes to the stabilization of the +2 oxidation state of the metal ion and to the maintenance of the hydrophilic/lipophilic balance of the whole molecule. The remaining three coordination sites of the $\mathrm{Ru}(\mathrm{II})$ ion are usually occupied by at least one leaving group and mono- or bidentate ligands, as can be seen in RAPTA-T and -C (VI) and RM175 (VII), respectively, which, among others, have become leads for Ru(II)-based complexes $[15,17,19]$.

Due to the biological relevance of sugars, the incorporation of a carbohydrate-containing ligand into platinum group metal complexes in general $[6,20]$ and into $\mathrm{Ru}(\mathrm{II})$-arene/arenyl complexes in particular [15] seems a rational choice for further drug design. Thus, several functional features of carbohydrates, such as their contribution to different cellular phenomena (e.g., to cell-cell recognition and adhesion), their crucial role in cellular energy supply, and their binding capacities to carbohydrate-specific proteins (e.g., lectins, glucose transporters, and glycoenzymes), can be exploited to obtain new platinum group metal complexes with anticancer potential $[15,20]$.

For several sugar-containing half-sandwich $\mathrm{Ru}(\mathrm{II})$ complexes, such as RAPTA analogs with glycofuranose-based phosphite ligands [15] (VIII) and $\mathrm{Ru}(\mathrm{II})$ complexes having 2,3-diamino-2,3-dideoxy-hexopyranoside [21] (IX) or 1,4-bis( $\beta$-D-glycopyranosyl)tetrazenetype $N, N$-chelating ligands [22] (X), the antiproliferative activity has already been justified. In addition, certain cyclopentadienyl-ruthenium(II) complexes with sugar-based heterocyclic mono- (XI, XII) or bidentate ligands (XIII) have also been shown to display low micromolar cytotoxic activity in human cervical carcinoma (HeLa) and colon cancer HCT116 cell lines [23-25].

Unlike organic drug molecules, the biological effects of metal complexes can be modulated by a wider array of parameters including size and charge of the species, hardsoft character of the metal ion, stability, inertness, and geometry of the complex, just to mention a few. In this regard, a more comprehensive study of Ru-sugar conjugatebased complexes, in which (A) the role of the metal chelating part of the ligand, (B) the basicity and binding strength of the coordinating donor atoms, and (C) the effect of the lipophilic/hydrophilic character of the complex, tuned by the presence/absence of various protecting groups at the sugar moiety, were explored, may provide a more detailed outlook of the structure-activity relationship (SAR) of these types of complexes.

As mentioned earlier, a rationale for the design and application of ruthenium complexes is to replace platinum compounds by ruthenium complexes in clinical settings. To the best of our knowledge, no real $\mathrm{C}$ - and $\mathrm{N}$-glycopyranosyl heterocyclic ligands as potential bidentate chelators have so far been used to obtain $\mathrm{Ru}(\mathrm{II})$ arene/arenyl complexes. In an ongoing project focused on these types of sugar derivatives capable of forming either five- or six-membered chelates with $\mathrm{Ru}(\mathrm{II})$, herein we report on the synthesis and comprehensive characterization of a set of $C$ - and $N$-glycopyranosyl azoles and their half-sandwich Ru-complexes (Figure 1, XIV). Since platinum complexes are widely used in the treatment of hematological and gynecological malignancies, the anticancer potential of the above ligands and their complexes were studied in comparison with Pt-complexes I-III against various human ovarian cancer cell lines.

\section{Results}

2.1. Chemistry

For the formation of the planned $\mathrm{Ru}(\mathrm{II})$ complexes, the sugar-based heterocyclic $\mathrm{N}, \mathrm{N}$-chelating ligands were prepared first. 
The synthesis of 1-( $\beta$-D-glucopyranosyl)-4-hetaryl-1,2,3-triazoles was accomplished by the well-known copper(I)-catalyzed azide-alkyne cycloaddition [26,27] (CuAAc). Thus, the easily available 2,3,4,6-tetra-O-acetyl- $\beta$-D-glucopyranosyl azide [28,29] (1) was treated with ethynyl heterocycles $\mathbf{a}$ and $\mathbf{b}$ in the presence of bis-triphenylphosphano-copper(I)butyrate $[30,31]$ to give the expected $O$-peracetylated 1 -( $\beta$-D-glucopyranosyl)-4-(pyridin-2yl)- and -4-(quinolin-2-yl)-1,2,3-triazoles (L-1a,b) in high yields (Table 1). Removal of the $O$-acetyl protecting groups of $\mathbf{L}-\mathbf{1} \mathbf{a}, \mathbf{b}$ was effected by the Zemplén method, resulting in the unprotected derivatives $\mathbf{L}-\mathbf{3} \mathbf{a}, \mathbf{b}$ in good yields. O-Perbenzoylation of compound $\mathbf{L}-\mathbf{3} \mathbf{a}$ was then also carried out to give the 1-(2', $3^{\prime}, 4^{\prime}, 6^{\prime}$-tetra-O-benzoyl- $\beta$-D-glucopyranosyl)-4(pyridin-2-yl)-1,2,3-triazole (L-2a) in excellent yield.

Table 1. Synthesis of 1-( $\beta$-D-glucopyranosyl)-4-hetaryl-1,2,3-triazoles.

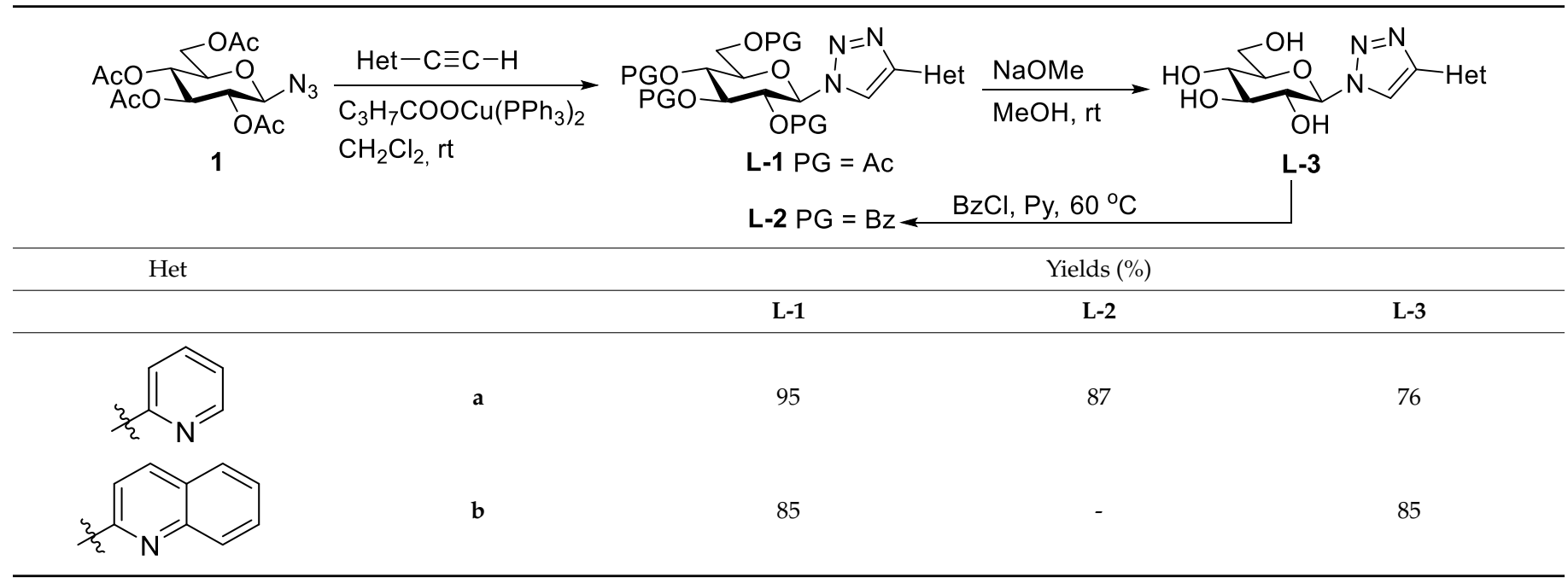

The preparation of the sugar-based 5-(pyridin-2-yl)-1,3,4-oxadiazoles was carried out via the ring transformation of the corresponding 5-substituted tetrazoles following our previously reported procedure [32]. Thus, tetrazoles $\mathbf{2}-\mathbf{5}$ were reacted with 2-picolinic acid in the presence of DCC under heating to furnish the desired 1,3,4-oxadiazoles L-4, L-6, L-7, and L-9 in moderate yields (Scheme 1). The O-deprotected derivatives L-10-L-12 were then obtained upon treatment of L-4, L-6, and L-7, respectively, with sodium methoxide in methanol. Under these conditions, the open-chain sugar derivative L-9 did not furnish the expected $O$-deacetylated derivative. This might be due to the ring opening of the oxadiazole, as it was demonstrated for 2-(D-arabino-1,2,3,4-tetraacetoxybutyl)-5-methyl1,3,4-oxadiazole [33]. Acetylation of $\mathbf{L}-\mathbf{1 0}$ and benzoylation of $\mathbf{L}-\mathbf{1 2}$ by using standard methods afforded the expected $O$-peracetylated 2-glucosyl-1,3,4-oxadiazole L-5 and the O-perbenzoylated 2-galactosyl-1,3,4-oxadiazole L-8, respectively, in high yields.

To get the desired cationic half-sandwich $\mathrm{Ru}(\mathrm{II})$ complexes, the above heterocyclic monosaccharide derivatives were reacted with the commercially available dichloro $\left(\eta^{6}-p\right.$ cymene)ruthenium(II) dimer ([( $\eta^{6}-p$-cym $\left.) \mathrm{RuCl}_{2}\right]_{2}, \mathbf{R u}$-dimer).

The complexation reactions of the Ru-dimer with an equimolar amount or a slight excess of the $O$-peracylated (L-1 and L-2) and the $O$-unprotected (L-3) 1-( $\beta$-D-glucopyranosyl)4-hetaryl-1,2,3-triazoles in the presence of the halide abstraction reagent $\mathrm{TlPF}_{6}$ in a $\mathrm{CH}_{2} \mathrm{Cl}_{2}-$ $\mathrm{MeOH}$ solvent mixture were smoothly accomplished at room temperature to give the $\mathrm{PF}_{6}{ }^{-}$salts of the expected $\left[\left(\eta^{6}-p-c y m\right) \mathrm{Ru}^{\mathrm{II}}(\mathrm{N}-\mathrm{N}) \mathrm{Cl}\right]^{+}$complexes $\mathbf{R u}-\mathbf{1}-\mathbf{R u}-\mathbf{3}$ in excellent yields (Scheme 2). The complexes containing the $O$-peracylated glucosyl-1,2,3-triazole ligands (Ru-1a,b and $\mathbf{R u - 2 a )}$ were stable and inert enough to be purified by column chromatography on silica gel, while the isolation of the highly polar complexes having the $O$-deprotected heterocyclic chelators $(\mathbf{R u}-\mathbf{3} \mathbf{a}, \mathbf{b})$ could be effected by crystallization. Due to the formation of a new stereogenic center on the metal ion and the chiral nature of the 
glucose unit, diastereomers of the complexes were formed in each case, whose separation could be achieved neither by column chromatography nor by crystallization.

Complexation of the Ru-dimer with the monosaccharide-based 5-(pyridin-2-yl)-1,3,4oxadiazoles (L-4-L-12) was also performed by applying the same procedure, resulting in diastereomeric mixtures of the corresponding $\left[\left(\eta^{6}-p\right.\right.$-cym $\left.) \mathrm{Ru}^{\mathrm{II}}(\mathrm{N}-\mathrm{N}) \mathrm{Cl}\right] \mathrm{PF}_{6}$ half-sandwich type complex molecules (Table 2). Column chromatographic purification for compounds $\mathbf{R u} \mathbf{- 4}-\mathbf{R u} \mathbf{- 9}$ and recrystallization for $\mathbf{R u - 1 0 - R u - 1 2}$ furnished the test molecules in moderate to high yields.

The formation of the complexes and the existence of the diastereomeric pairs were confirmed by ${ }^{1} \mathrm{H}$ - and ${ }^{13} \mathrm{C}-\mathrm{NMR}$ spectroscopy in each case. As a representative, the superposition of the ${ }^{1} \mathrm{H}$ - and ${ }^{13} \mathrm{C}-\mathrm{NMR}$ spectra of $\mathbf{R u}-7$, the free ligand $\mathbf{L - 7}$, and the Rudimer, respectively, are presented in Figure 2. Generally, the conversion of Ru-dimer into the corresponding $\left[\left(\eta^{6}-p\right.\right.$-cym $\left.) \mathrm{Ru}^{\mathrm{II}}(\mathrm{N}-\mathrm{N}) \mathrm{Cl}\right] \mathrm{PF}_{6}$ complexes $(\mathbf{R u}-\mathbf{1}-\mathbf{R u}-\mathbf{1 2})$ led to remarkable downfield shifts of the aromatic $p$-cymene signals in both the ${ }^{1} \mathrm{H}$ - and the ${ }^{13} \mathrm{C}-\mathrm{NMR}$ spectra. No significant changes in the chemical shifts of the proton and carbon resonances of the sugar moiety were observed, except for those which were close to the coordination sphere. Thus, $\mathrm{H}-1^{\prime}$ protons of the sugar-based heterocyclic ligands usually displayed noticeable downfield shifts up to $0.05-0.27 \mathrm{ppm}$ upon coordination. On the other hand, e.g., in the case of the $O$-acyl protected glycosyl-1,3,4-oxadiazole derivatives L-4-L-8 the coordination resulted in either a downfield or an upfield shift of the $\mathrm{H}-2^{\prime}$ resonances depending on the diastereomers formed. The formation of the 5-membered chelates with the participation of heterocyclic aglycone parts was also shown by the change in the chemical shift of several heteroaromatic signals. For example, in case of the 2-pyridyl substituted derivatives, welltraceable and consistent changes were observed in the appearance of the proton and carbon signals of the pyridine ring. For example, the H-6 and C-6 signals of the pyridine ring showed downfield shifts up to $0.48-0.83 \mathrm{ppm}\left({ }^{1} \mathrm{H}-\mathrm{NMR}\right)$ and $5.7-7.8 \mathrm{ppm}\left({ }^{13} \mathrm{C}-\mathrm{NMR}\right)$, respectively, as a result of the coordination. A more detailed collection of these data can be found in Tables S1-S8 in the Supplementary Materials.

Gly

2-5
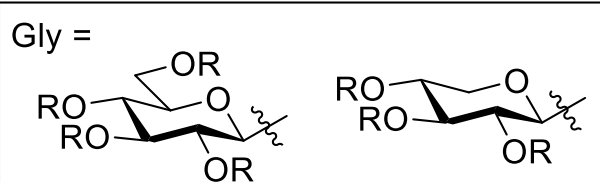

$\mathrm{R}=\mathrm{Bz} 2, \mathrm{~L}-4$

$R=A C L-5$

$\mathrm{R}=\mathrm{H} \quad \mathrm{L}-10$

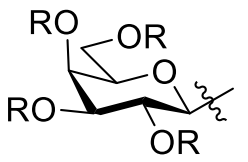

$\mathrm{R}=\mathrm{Ac}$ 4, L-7

$\mathrm{R}=\mathrm{Bz} \mathrm{L}-8$

$\mathrm{R}=\mathrm{H} \quad \mathrm{L}-12$

$\mathrm{R}=\mathrm{Bz} \quad 3, \mathrm{~L}-6$

$\mathrm{R}=\mathrm{H} \quad \mathrm{L}-11$

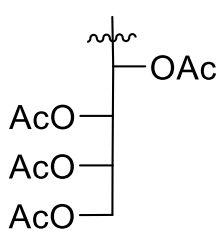

5, L-9
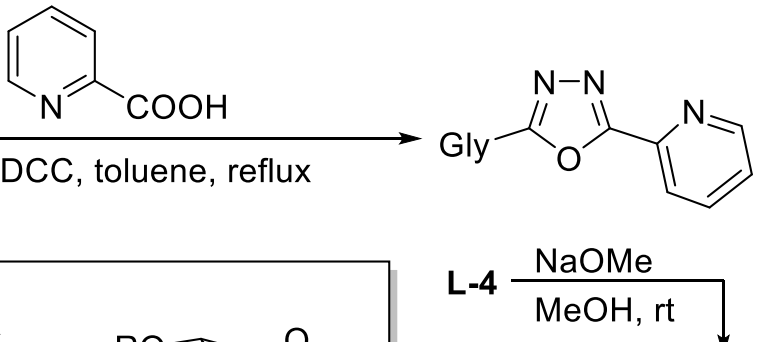

$\mathrm{L}-5 \frac{\mathrm{Ac}_{2} \mathrm{O}, \mathrm{Py}}{60^{\circ} \mathrm{C}} \mathrm{L}-10$
Yield (\%)

L-4 35

L-5 90

L-6 58

L-7 50

L-8 81

L-9 13

L-10 87

L-11 35

L-12 78

Scheme 1. Synthesis of the monosaccharide-based 5-(pyridin-2-yl)-1,3,4-oxadiazoles. 


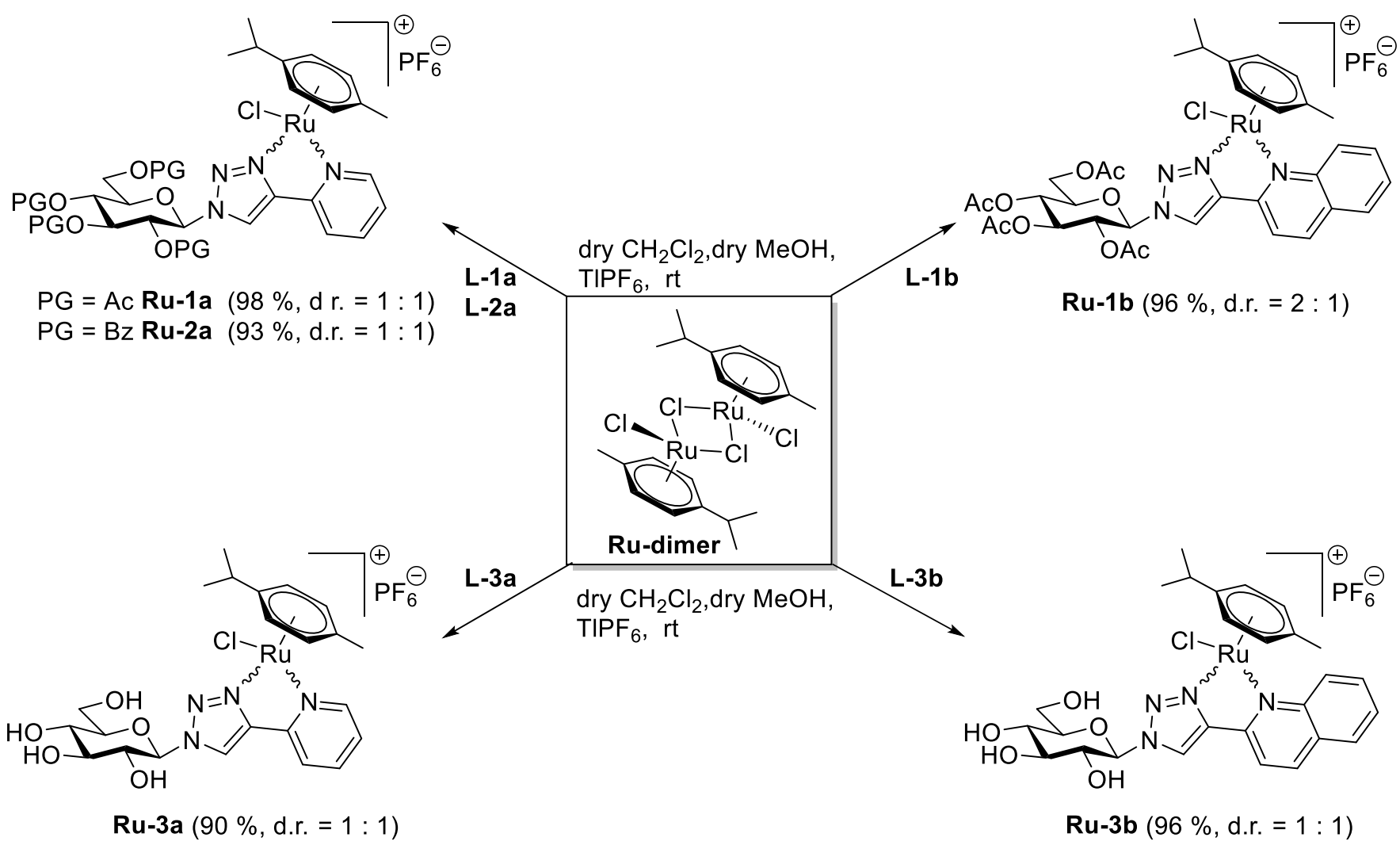

Scheme 2. Synthesis of $\left[\left(\eta^{6}-p\right.\right.$-cym $\left.) \mathrm{Ru}^{\mathrm{II}}(\mathrm{N}-\mathrm{N}) \mathrm{Cl}\right] \mathrm{PF}_{6}$ complexes containing 1-( $\beta$-D-glucopyranosyl)-4-hetaryl-1,2,3-triazole ligands.

Table 2. Synthesis of $\left[\left(\eta^{6}-p-c y m\right) \mathrm{Ru}^{\mathrm{II}}(\mathrm{N}-\mathrm{N}) \mathrm{Cl}\right] \mathrm{PF}_{6}$ complexes containing the monosaccharide-based 5-(pyridin-2-yl)-1,3,4oxadiazoles.

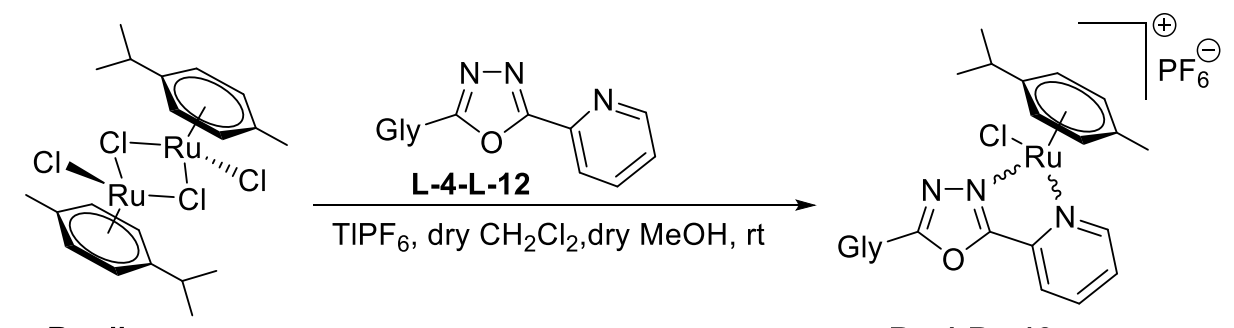

Ru-dimer

Ru-4-Ru-12

(2) (Diastereomeric Ratio)



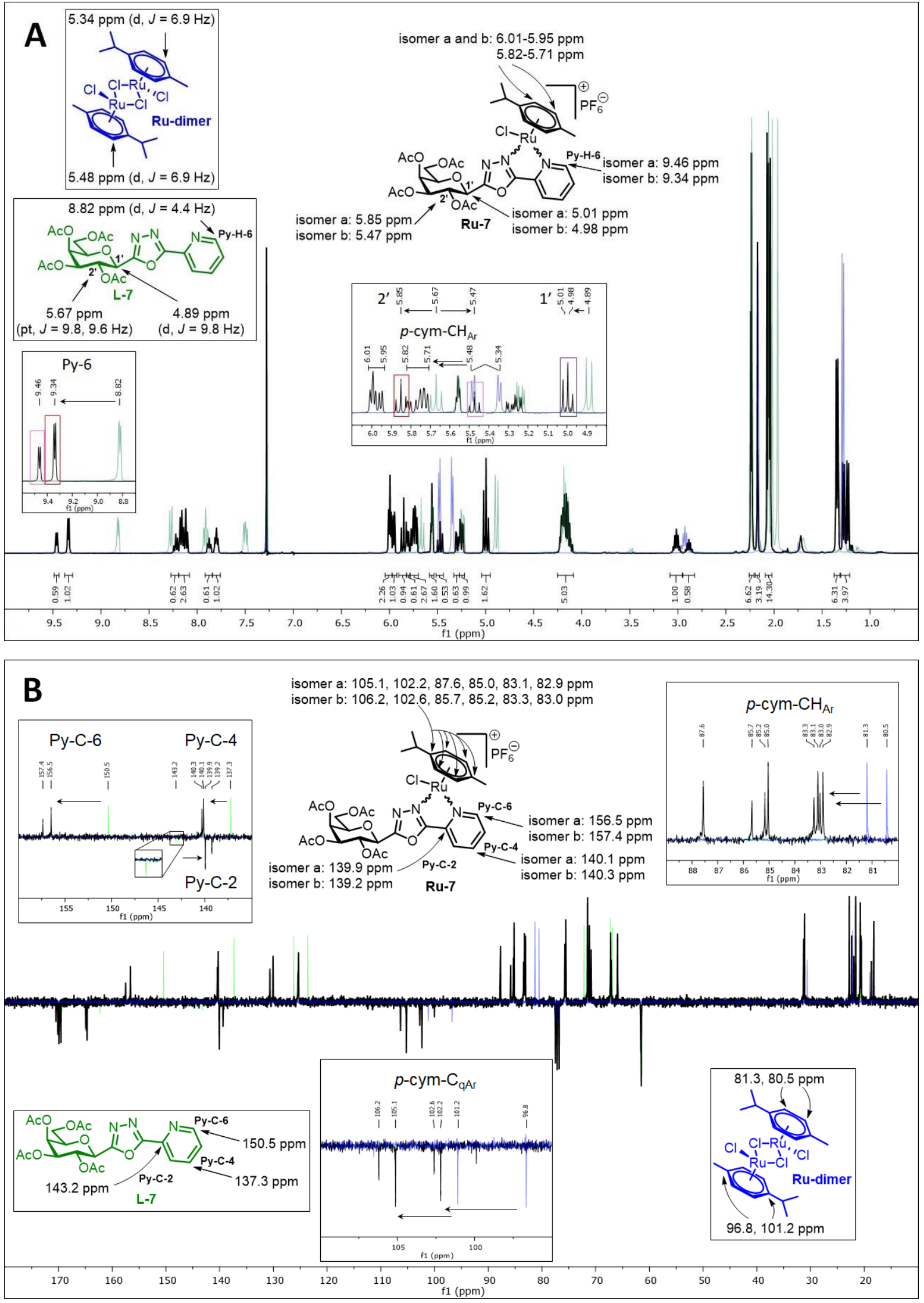

Figure 2. Superposition of the ${ }^{1} \mathrm{H}-\mathrm{NMR}(\mathbf{A})$ and ${ }^{13} \mathrm{C}-\mathrm{NMR}$ (B) spectra of Ru-7 (black), ligand L-7 (green), and Ru-dimer (blue) in $\mathrm{CDCl}_{3}$. 
The aqueous stability of the complexes was also studied over time. As an example, the time dependence of the NMR spectra of Ru-3a is shown in Figure S1. The small shifts of signals attributable to the structural change of the complex can be observed; however, by adding $\mathrm{KCl}$ to the 2 day old equilibrated sample, the original signals could be recovered. This unambiguously proves that only the exchange of the coordinating chloride ion by a water molecule occurred in a reversible manner without affecting the dissociation of the five-membered $N, N$ chelate.

For comparative biological studies, two additional $\mathrm{Ru}(\mathrm{II})$ complexes containing nonsugar based ligands (Scheme 3, Ru-13 and Ru-14) were also synthesized, starting from the Ru-dimer with 1-phenyl-4-(pyridine-2-yl)-1,2,3-triazole [34] (L-13) and 2-phenyl-5(pyridine-2-yl)-1,3,4-oxadiazole [35,36] (L-14), respectively.<smiles>c1ccc(-n2cc(-c3ccccn3)nn2)cc1</smiles>

L-13

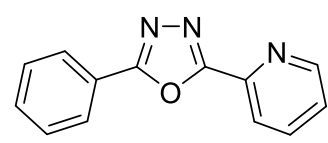

L-14

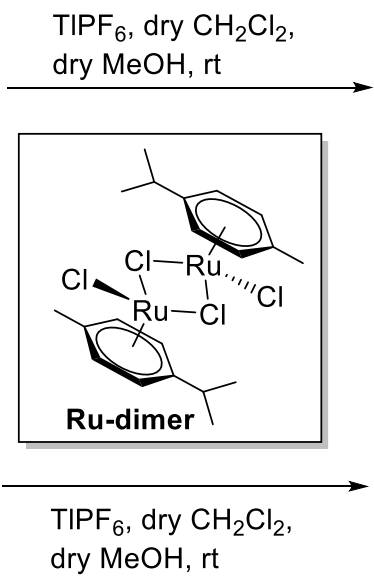

dry $\mathrm{MeOH}$, rt
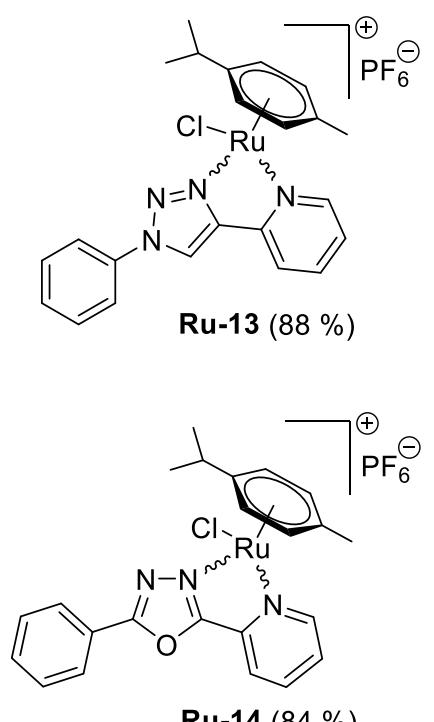

Ru-14 (84\%)

Scheme 3. Synthesis of $\left[\left(\eta^{6}-p-c y m\right) \mathrm{Ru}^{\mathrm{II}}(\mathrm{N}-\mathrm{N}) \mathrm{Cl}\right] \mathrm{PF}_{6}$ complexes containing non-sugar-based azole ligands.

\subsection{Identification of Ruthenium Compounds with Antineoplastic Properties}

We screened 14 ligands and their ruthenium complexes, bringing up the number of compounds to 28 in a concentration range of $100-0.0017 \mu \mathrm{M}$. The compounds were tested in an assay aiming to assess short-term toxicity (methylthiazolyldiphenyl-tetrazolium bromide (MTT) reduction assay, $4 \mathrm{~h}$ ) and long-term cytostasis or cytotoxicity (sulforhodamine B (SRB) proliferation assay, $48 \mathrm{~h}$ ) on A2780 human ovarian carcinoma cells. We found four complexes, Ru-2a, $\mathbf{R u - 4}, \mathbf{R u}-\mathbf{6}$, and $\mathbf{R u}-\mathbf{8}$, possessing cytostatic properties in both long-term SRB and short-term MTT assays (Figure 3A,B). The uncomplexed ligands L-2a, L-4, L-6, and L-8 had no biological activity (Figure 3A,B).

\subsection{Ruthenium Compounds Have Similar Inhibitory Characteristics to Platinum Compounds}

Next, we assessed the four active complexes, Ru-2a, Ru-4, Ru-6, and Ru-8, and the corresponding ligands, L-2a, L-4, L-6, and L-8, in detail. All compounds were tested on two ovarian cancer cell lines (A2780 and ID8) and on human primary skin fibroblasts (non-transformed, primary cells) in MTT and SRB assays. MTT assays were performed $4 \mathrm{~h}$ post treatment and indicated rapid toxicity of the compounds, while SRB assays were performed 2 days post treatment and represented long-term cytostasis or toxicity.

None of the free ligands exerted rapid toxicity on any of the cell lines in short-term MTT assays (Figure 4). Nevertheless, the application of Ru-2a and Ru-8 above $10 \mu \mathrm{M}$ concentration reduced the MTT signal in A2780 and ID8 cells. Ru-6 reduced the MTT signal in ID8 cells at $100 \mu \mathrm{M}$, and a similar trend was observed on A2780 cells. Although it was not statistically significant, $\mathbf{R u}-\mathbf{4}$ led to a similar reduction in MTT signal at $100 \mu \mathrm{M}$ 
in A2780 and ID8 cells. Complexes Ru-2a, Ru-4, Ru-6, and $\mathbf{R u - 8}$ had no effect on primary fibroblasts in MTT assays.

A

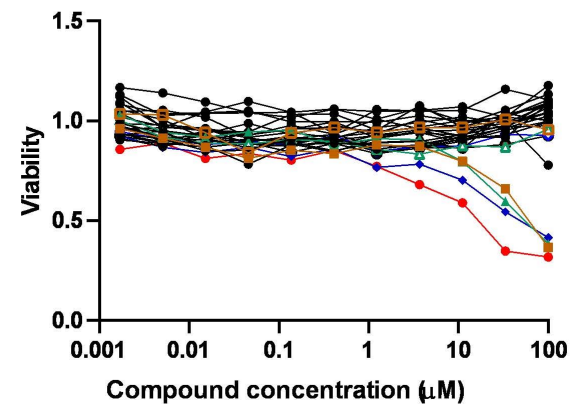

B

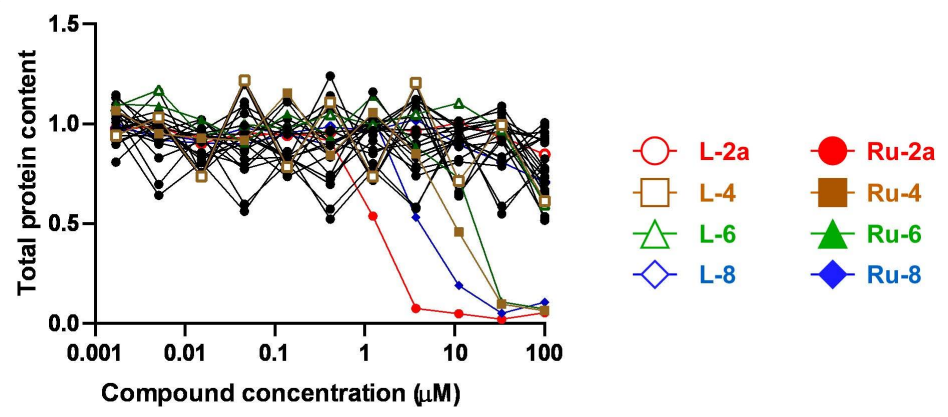

Figure 3. Screening of ruthenium complexes for cytostatic properties. (A,B) A total of $1 \times 10^{4}$ (on panel A, MTT assays) or $3 \times 10^{3}$ (on panel B, SRB assays) A2780 cells were plated on 96-well plates. (A) Cells were treated with the compounds indicated for $4 \mathrm{~h}$, and then the MTT assay was performed. (B) Cells were treated with the compounds indicated for $48 \mathrm{~h}$, and then the SRB assay was performed. Those molecules that were used in the subsequent studies are highlighted in color. All assays were performed in duplicate; all data represent three biological replicates. Values were normalized to vehicle-treated cells, where the absorbance of vehicle-treated cells was equal to 1.

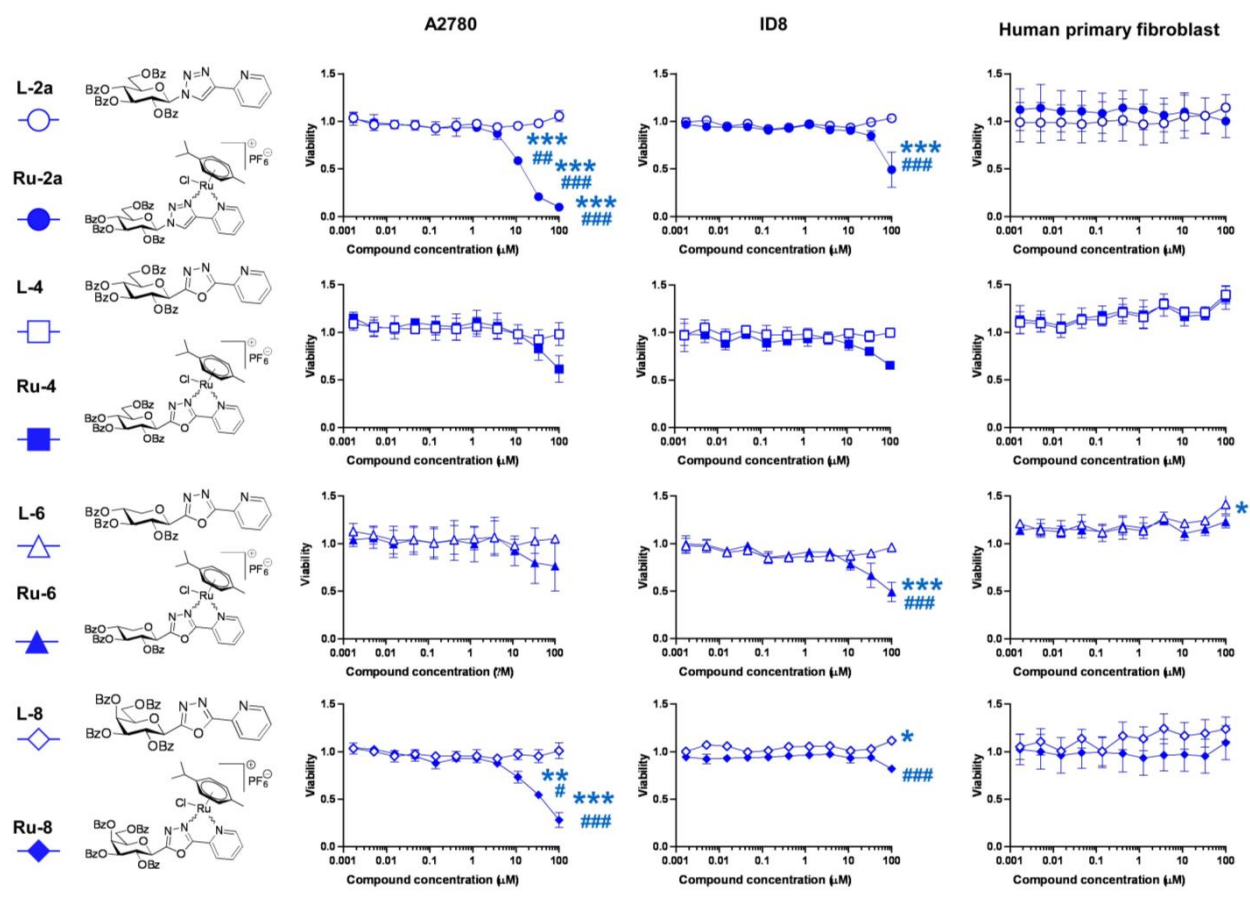

Figure 4. Assessment of the bioactive ruthenium complexes for acute toxicity. A total of $1 \times 10^{4}$ A2780 cells, $8 \times 10^{3}$ ID8 cells, and $6 \times 10^{3}$ primary fibroblasts were plated on 96-well plates. Cells were treated with the compounds in the concentrations indicated for $4 \mathrm{~h}$, and then the MTT assay was performed. Data are represented as the average \pm SEM from three biological replicates; individual assays were performed in duplicate. Normality was tested; the Ru-4/L4 fibroblast dataset had a normal distribution, Ru-4/L4 ID8 dataset normality was achieved by logarithmic transformation, and the Ru-4/L-4 A2780, Ru-6/L-6 A2780, Ru-8/L-8 A2780, Ru-2a/L-2a A2780, Ru-6/L-6 ID8, Ru-8/L-8 ID8, Ru-2a/L-2a ID8, Ru-4/L-4 fibroblast, Ru-8/L-8 fibroblast, and Ru-2a/L2a fibroblast datasets were normalized using the Box-Cox normalization method. Statistical significance was determined using a two-way ANOVA test, and all measurement points were compared with each other; ${ }^{*}{ }^{* *}$, and ${ }^{* * *}$ indicate statistically significant differences between vehicle-treated (control) and free ligand/ruthenium complex-treated cells at $p<0.05, p<0.01$, and $p<0.001$, respectively; $\#$, , and ${ }^{\# \#}$ indicate statistically significant differences between free ligand-treated and ruthenium complex-treated cells at $p<0.05, p<0.01$, and $p<0.001$, respectively. Values were normalized to vehicle-treated cells, where the absorbance of vehicle-treated cells was equal to 1 . 
Ruthenium complexes $\mathbf{R u - 2 a , ~ R u - 4 , ~ R u - 6 , ~ a n d ~ R u - 8 ~ w e r e ~ c y t o s t a t i c , ~ w h i l e ~ n o n e ~ o f ~}$ the corresponding ligands (L-2a, L-4, L-6, and L-8) had cytostatic properties in long-term SRB assays on A2780 and ID8 cells (Figure 5). On primary human fibroblasts, the ligands, L-2a, L-4, L-6, and L-8, as well as two complexes, $\mathbf{R u - 4}$ and $\mathbf{R u - 8 , ~ h a d ~ n o ~ e f f e c t . ~ I n ~ c o n t r a s t , ~}$ Ru-2a and Ru-6 reduced the SRB signal at $100 \mu \mathrm{M}$ on fibroblasts.

A2780

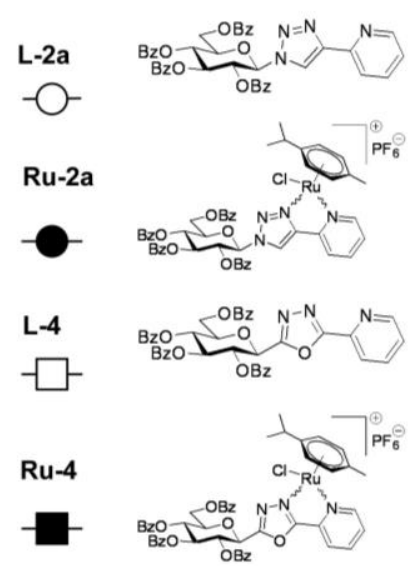

L-6

$-\Delta$

Ru-6
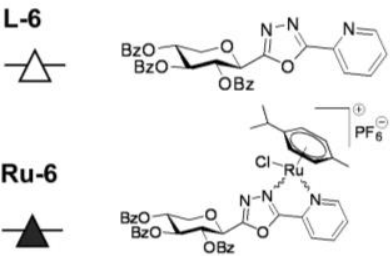

L-8

$\checkmark$

Ru-8

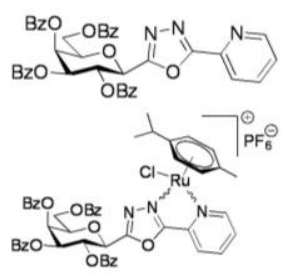

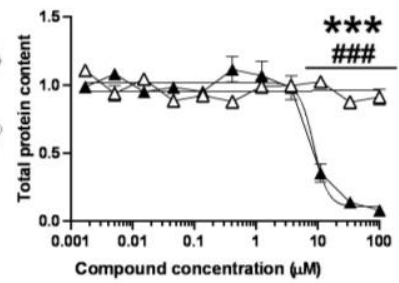
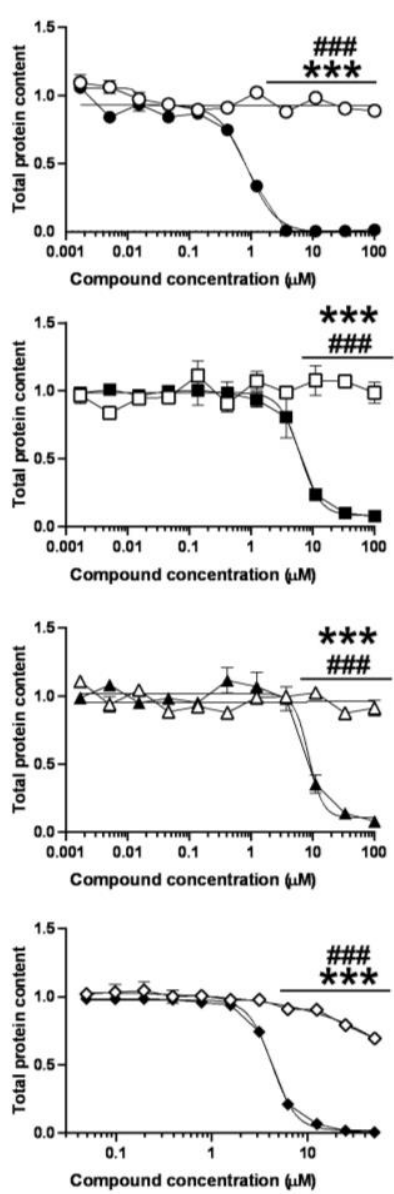

ID8
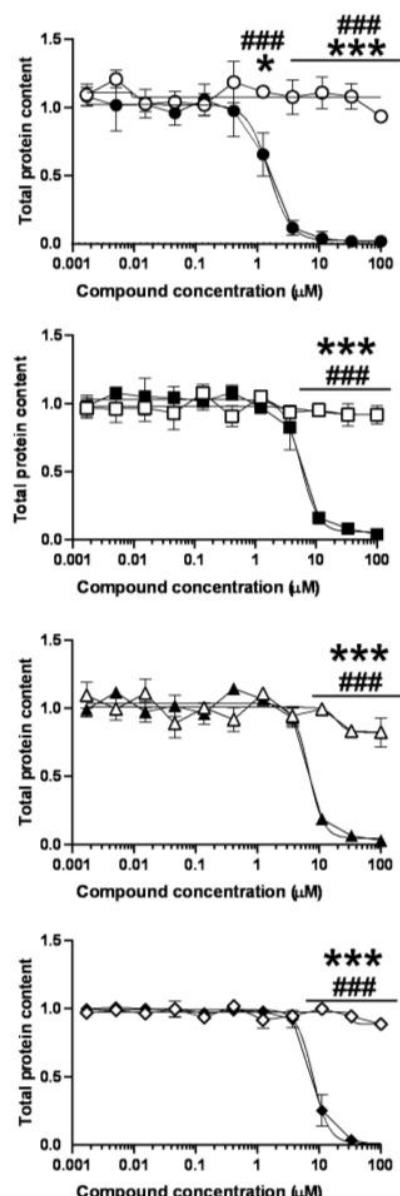

Human primary fibroblast
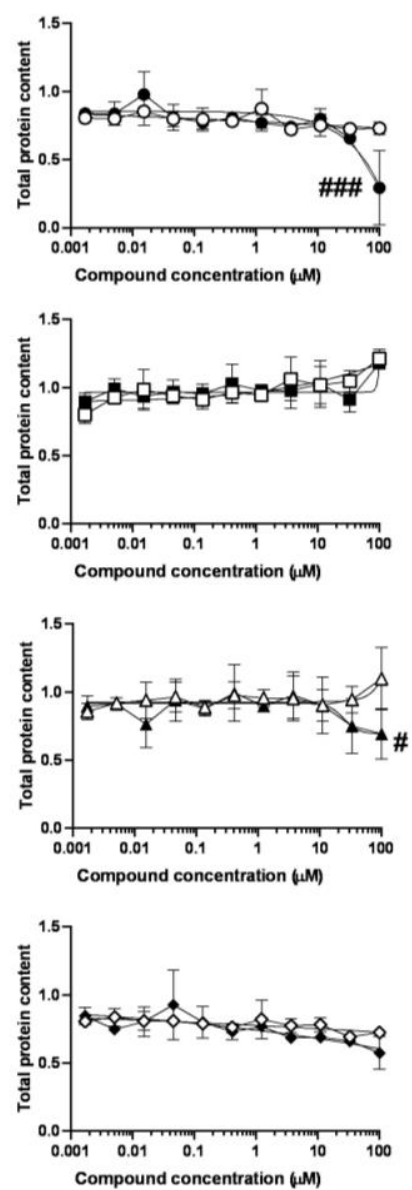

Figure 5. Assessment of the bioactive ruthenium complexes for cytostatic activity. A total of $3 \times 10^{3}$ A2780 cells, $2 \times 10^{3}$ ID8 cells, and $4 \times 10^{3}$ primary fibroblasts were plated on 96-well plates. Cells were treated with the compounds in the concentrations indicated for $48 \mathrm{~h}$, and then the SRB assay was performed. Data are represented as the average \pm SEM from three biological replicates; individual assays were performed in duplicate. Normality was tested; the $\mathbf{R u}-\mathbf{4} / \mathrm{L}$ 4 A2780, Ru-6/L-6 A2780, Ru-8/L-8 A2780, Ru-4/L-4 ID8, Ru-6/L-6 ID8, Ru-8/L-8 ID8, and Ru-2a/L-2a ID8 datasets had a normal distribution, Ru-2a/L-2a A2780 and Ru-6/L-6 fibroblast dataset normality was achieved by logarithmic transformation, and the Ru-4/L-4 fibroblast, Ru-8/L-8 fibroblast, and Ru-2a/L-2a fibroblast datasets were normalized using the Box-Cox normalization method. Statistical significance was determined using a two-way ANOVA test, and all measurement points were compared with each other; * and ${ }^{* * *}$ indicate statistically significant differences between vehicletreated (control) and free ligand/ruthenium complex-treated cells at $p<0.05, p<0.01$, and $p<0.001$, respectively; ${ }^{\#}$ and \#\#\# indicate statistically significant differences between free ligand-treated and ruthenium complex-treated cells at $p<0.05$, $p<0.01$, and $p<0.001$, respectively. Nonlinear regression was performed on the data. Values were normalized to vehicle treated cells, where the absorbance of vehicle-treated cells was equal to 1 .

Cytostasis in the long term can be due to enhanced cell death. To exclude that possibility, we performed annexin V-propidium iodide (PI) double staining. Treating A2780 cells with $\mathbf{R u - 2 a , ~ R u - 4 , ~ R u - 6 , ~ a n d ~ R u - 8 ~ d i d ~ n o t ~ l a r g e l y ~ i n c r e a s e ~ t h e ~ p r o p o r t i o n s ~ o f ~}$ PI-positive, annexin V-positive, and double-positive cells in contrast to hydrogen peroxide that was used as a positive control whether at $2 \mathrm{~h}, 4 \mathrm{~h}$, or $48 \mathrm{~h}$ post treatment (Figure 6). 
The $4 \mathrm{~h}$ and $48 \mathrm{~h}$ timepoints were chosen to be the same as those used in the previous assays. The $2 \mathrm{~h}$ timepoint was found in our previous study to be optimal for the induction of apoptosis, marked by phosphatidylserine exposure [37-39].
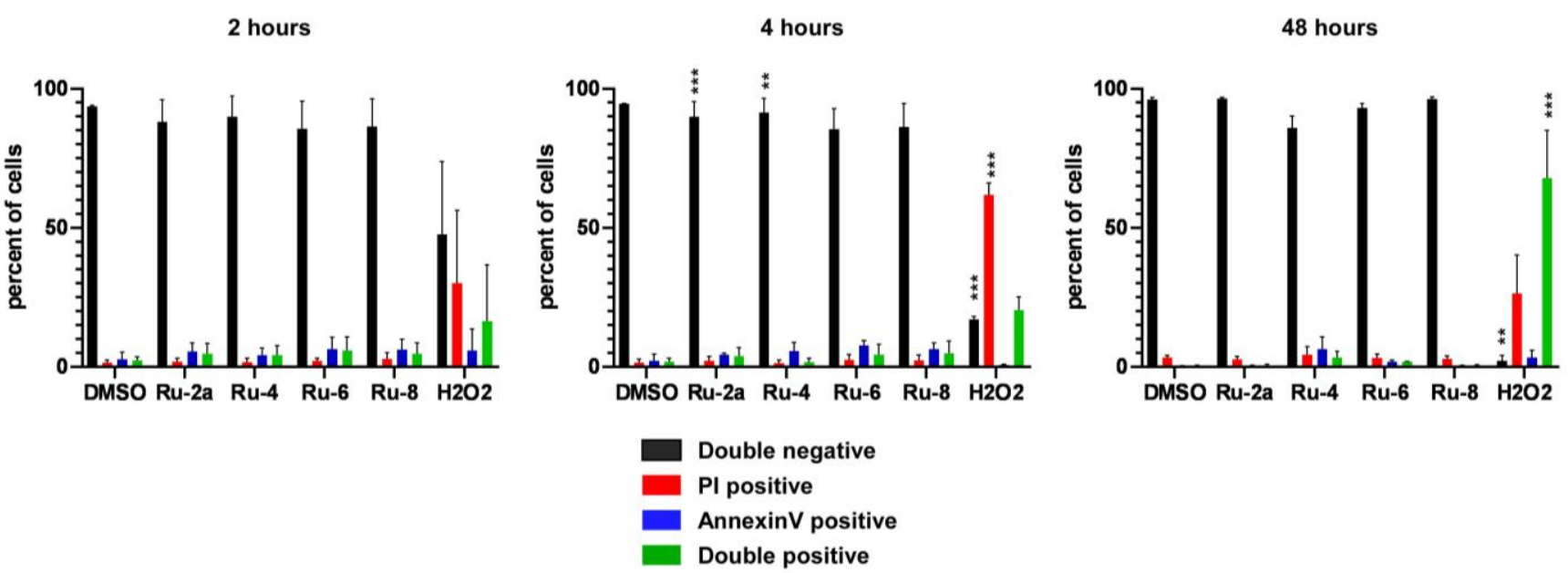

Figure 6. Ruthenium complexes do not induce cell death. A total of $1 \times 10^{6} \mathrm{~A} 2780$ cells were plated on six-well plates and were treated with ruthenium complexes (Ru-2a at $1.3 \mu \mathrm{M}, \mathbf{R u}-\mathbf{4}$ at $6.2 \mu \mathrm{M}, \mathbf{R u}-\mathbf{6}$ at $8.5 \mu \mathrm{M}$, and $\mathbf{R u}-\mathbf{8}$ at $3.7 \mu \mathrm{M})$ and $300 \mu \mathrm{M}$ hydrogen peroxide for $48 \mathrm{~h}$. Cells were then stained with Annexin V and propidium iodide (PI), and cells were subjected to flow cytometry as described in Section 5. The percentages of cells in the quadrants are plotted. Data are presented as the average \pm SEM from three biological replicates; individual assays were performed in duplicate. Normality was tested; on all datasets, Box-Cox normalization was performed to achieve a normal distribution. Statistical significance was determined using a two-way ANOVA test, and all measurement points were compared with each other; ${ }^{* *}$ and ${ }^{* * *}$ indicate statistically significant differences between vehicle-treated (control) and treated cells (ruthenium complexes or $300 \mu \mathrm{M}$ $\mathrm{H}_{2} \mathrm{O}_{2}$ ) corresponding to the same quadrant (e.g., vehicle-treated double-negative cells vs. Ru-2a-treated double-negative cells) at $p<0.01$ and $p<0.001$, respectively.

Since ruthenium complexes are regarded as alternatives to platinum-centered drugs [6], we used the currently therapeutically available platinum-based drugs cisplatin (I), oxaliplatin (II), and carboplatin (III) as reference compounds and tested them on A2780 and ID8 cells, as well as on primary human fibroblasts. Platinum drugs had no effect in MTT assays (Figure 7A), while they were cytostatic on A2780 and ID8 cells in SRB assays (Figure 7B). Carboplatin and oxaliplatin had no effect on primary human fibroblasts in SRB assays, while cisplatin was cytostatic above $10 \mu \mathrm{M}$ (Figure 7).

To compare the inhibitory properties of $\mathbf{R u}-\mathbf{2 a}, \mathbf{R u}-\mathbf{4}, \mathbf{R u}-\mathbf{6}$, and $\mathbf{R u}-\mathbf{8}$, we performed a nonlinear regression of the long-term cytostatic curves (SRB curves) (Figures 5 and 7B, Table 3). The $\mathrm{IC}_{50}$ values of Ru-2a, Ru-4, Ru-6, and Ru-8 fell between 0.9 and $9 \mu \mathrm{M}$, and the A2780 cells were more sensitive to ruthenium complexes as compared to ID8 cells (Table 3). Ru-2a had the lowest $\mathrm{IC}_{50}$ value in A2780 and ID8 cells $(0.9$ and $1.5 \mu \mathrm{M}$, respectively). The $\mathrm{IC}_{50}$ values of the ruthenium complexes $(0.9-9 \mu \mathrm{M})$ were comparable to or lower than those of the platinum compounds $(0.1-28 \mu \mathrm{M})$ (Table 3).

In addition to the $\mathrm{IC}_{50}$ value, regression analysis yielded the Hill slope. The Hill slope is a readout, characterized by the slope of the curve, that provides information on the binding characteristics of a compound [40]. The Hill slope of platinum compounds on A2780 and ID8 cells was in the range of 0.6-1.6. In stark contrast to that, the Hill slope of the ruthenium complexes was in the range of 1.5-3.7 (Table 3). A higher Hill slope suggests higher cooperativity upon the binding of the ruthenium complexes to target biomolecules than in the case of platinum compounds. 
A2780
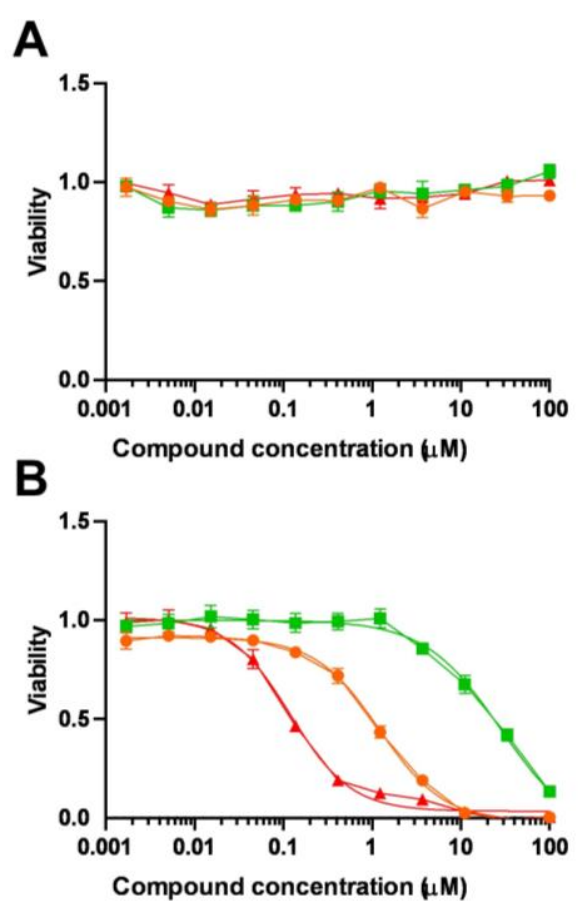

ID8
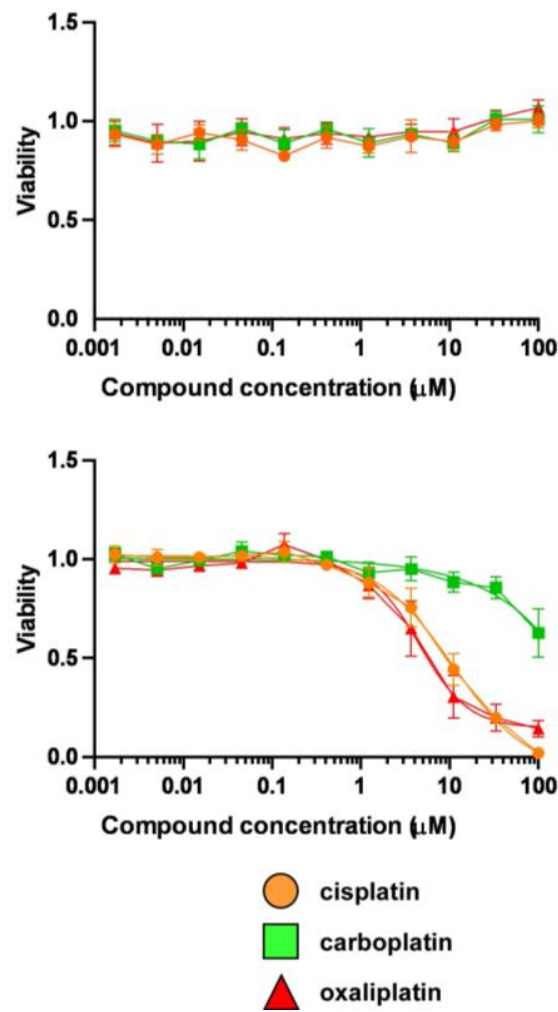

Fibroblast
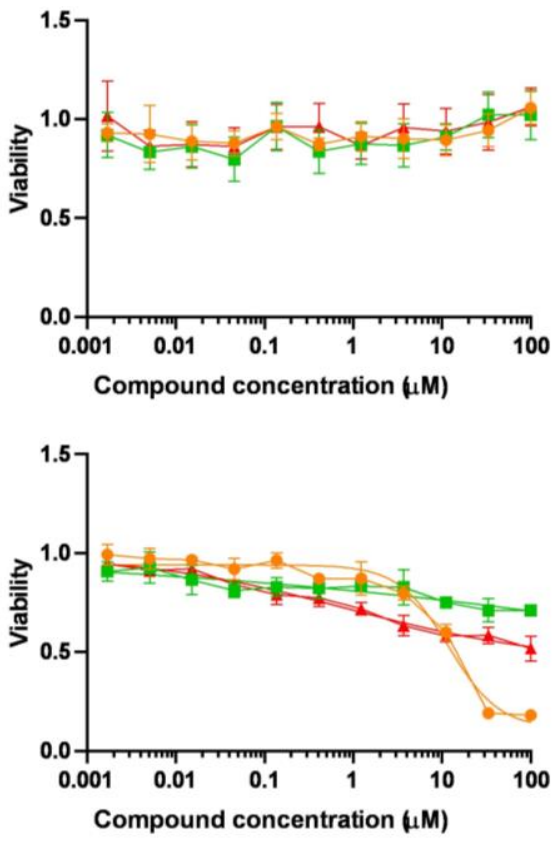

Figure 7. Determination of the cytotoxic and cytostatic activity of platinum compounds. (A) A total of $1 \times 10^{4}$ A2780 cells, $8 \times 10^{3}$ ID8 cells, and $6 \times 10^{3}$ primary fibroblasts were plated on 96-well plates. Cells were treated with the compounds in the concentrations indicated for $4 \mathrm{~h}$, and then the MTT assay was performed. (B) A total of $3 \times 10^{3}$ A2780 cells, $2 \times 10^{3}$ ID 8 cells, and $4 \times 10^{3}$ primary fibroblasts were plated on 96-well plates. Cells were treated with the compounds in the concentrations indicated for $48 \mathrm{~h}$, and then the SRB assay was performed. Nonlinear regression was performed on the data. Values were normalized to vehicle-treated cells, where the absorbance of vehicle-treated cells was equal to 1.

Table 3. The lipophilicity parameters $(\log \mathrm{D})$ and kinetic properties of the biologically active ruthenium complexes identified in the study and the reference platinum compounds $\left(\mathrm{IC}_{50}(\mu \mathrm{M})\right)$.

\begin{tabular}{|c|c|c|c|c|c|c|c|c|c|c|c|c|c|}
\hline \multirow{2}{*}{ Compound } & \multirow{2}{*}{$\log D$} & \multicolumn{2}{|r|}{ A2780 } & \multicolumn{2}{|r|}{ ID8 } & \multicolumn{2}{|c|}{ Fibroblast } & \multicolumn{2}{|r|}{ U251 } & \multicolumn{2}{|c|}{ MCF7 } & \multicolumn{2}{|c|}{ Capan2 } \\
\hline & & $\mathrm{IC}_{50}$ & Hill Slope & $\mathrm{IC}_{50}$ & Hill Slope & $\mathrm{IC}_{50}$ & Hill Slope & $\mathrm{IC}_{50}$ & Hill Slope & $\mathrm{IC}_{50}$ & Hill Slope & $\mathrm{IC}_{50}$ & Hill Slope \\
\hline Ru-2a & 2.85 & 0.9 & 1.95 & 1.53 & 2.50 & N/A & 0.78 & 2.82 & 1.75 & 1.29 & 1.85 & 2.18 & 2.43 \\
\hline Ru-4 & 2.41 & 6.19 & 2.62 & 5.66 & 3.04 & N/A & N/A & 4.17 & 2.46 & 3.74 & 2.01 & 3.27 & 1.81 \\
\hline Ru-6 & 2.04 & 8.54 & 3.74 & 6.76 & 3.59 & 24.63 & 3.52 & 6.61 & 2.13 & 6.69 & 2.13 & 4.97 & 1.66 \\
\hline Ru-8 & 2.44 & 4.27 & 3.50 & 7.94 & 3.31 & N/A & N/A & 4.49 & 2.50 & 3.75 & 2.06 & 3.82 & 1.66 \\
\hline Ru-13 & 0.44 & 11.97 & 1.57 & & & & & & & & & & \\
\hline Ru-14 & 1.63 & 513.5 & 0.77 & & & & & & & & & & \\
\hline Cisplatin & & 1.21 & 1.20 & 10.81 & 0.99 & 11.90 & 1.53 & & & & & & \\
\hline Carboplatin & & 27.98 & 1.02 & $\mathrm{~N} / \mathrm{A}$ & 0.62 & N/A & $\mathrm{N} / \mathrm{A}$ & & & & & & \\
\hline Oxaliplatin & & 0.12 & 1.27 & 4.59 & 1.58 & 0.83 & 0.37 & & & & & & \\
\hline
\end{tabular}

N/A—could not be calculated/had no effect.

2.4. The Biological Activity of Ruthenium Complexes Is Dependent on Reactive Oxygen Species Production

Currently available ruthenium complexes with antineoplastic activity have diverse modes of action involving (mitochondrial) reactive oxygen species production $[9,15,41,42]$ and the induction of DNA damage $[43,44]$. We detected an increase in the expression of an 
oxidative stress marker, 4-hydroxy-nonenal (4HNE), at the level of the whole lane, as well as when a specific band was assessed, in A2780 cells treated with the active ruthenium complexes $\mathbf{R u - 2 a}, \mathbf{R u}-\mathbf{4}, \mathbf{R u}-\mathbf{6}$, and $\mathbf{R u} \mathbf{- 8}$ corresponding to the $\mathrm{IC}_{50}$ values (Figure 8).
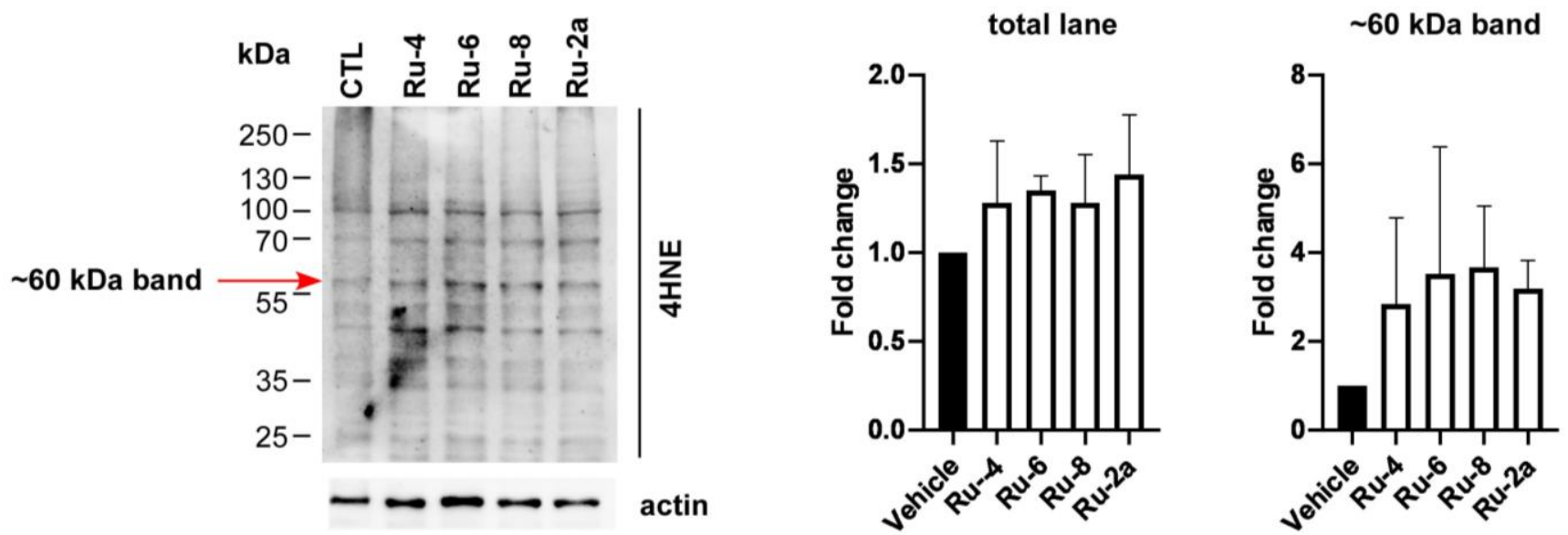

Figure 8. Ruthenium complexes induce reactive oxygen species production. A total of $1 \times 10^{6}$ A2780 cells were plated on six-well plates. Cells were treated with Ru-2a at $1.3 \mu \mathrm{M}, \mathbf{R u}-\mathbf{4}$ at $6.2 \mu \mathrm{M}, \mathbf{R u}-\mathbf{6}$ at $8.5 \mu \mathrm{M}$, and Ru-8 at $3.7 \mu \mathrm{M}$ for $48 \mathrm{~h}$. Then, the cells were harvested, and the protein lysate was prepared. Subsequently, $20 \mu$ p protein was separated by SDS-PAGE on an $8 \%$ gel, followed by Western blotting, and the blot was stained with $4 \mathrm{HNE}$ and actin antibodies. Densitometry values were normalized to the control. Data are represented as the average \pm SEM from three biological replicates. Since there was no variance in the control group, we did not perform statistical analysis. Values were normalized to vehicle-treated cells, where the absorbance of vehicle-treated cells was equal to 1.

We assessed whether oxidative stress had a role in the cytostatic effects exerted by Ru-2a, Ru-4, Ru-6, and Ru-8. To that end, we tried to revert the cytostatic effects of ruthenium complexes using strong reductants such as reduced glutathione (GSH) and $N$-acetyl-cysteine (NAC). Furthermore, we also tested MitoTEMPO, a mitochondrially targeted antioxidant that can efficiently detoxify mitochondria-derived reactive oxygen species $[45,46]$. GSH and NAC cotreatment attenuated the cytostatic effects induced by Ru-2a, Ru-4, Ru-6, and Ru-8 (Figure 9A) pointing to the causative role of reactive oxygen species production in cytostasis. Nevertheless, MitoTEMPO did not modulate the effects of Ru-2a, Ru-4, Ru-6, and Ru-8 (Figure 9A) suggesting that mitochondria are not the source of the reactive oxygen species.

As thiols are soft Lewis bases and ruthenium is a soft Lewis acid, excess amounts of GSH or NAC can lead to the disassembly of ruthenium complexes. To provide evidence against this scenario, we applied another antioxidant, vitamin E, that does not have thiol groups. The application of vitamin E, similar to GSH and NAC, attenuated the cytostatic effects of the bioactive ruthenium complexes (Figure 9B), providing further evidence on the involvement of reactive oxygen species. Interestingly, treatment of the cells with Trolox, a derivative of vitamin E lacking the apolar phytyl chain, did not provide protection against ruthenium compounds (Figure 9C).

Reactive oxygen species production leads to DNA damage and poly(ADP-ribose) polymerase (PARP) activation $[47,48]$. Certain ruthenium complexes were shown to potentiate the effects of PARP inhibitors $[41,42,49,50]$. We assessed whether Ru-2a, Ru-4, Ru-6, and Ru-8 have similar properties by treating cells with $3 \mu \mathrm{M}$ rucaparib, a clinically available potent PARP inhibitor. Rucaparib reduced cell proliferation in agreement with previous publications (e.g., [51]) (Figure 10). When we performed nonlinear regression analysis to assess the $\mathrm{IC}_{50}$ values, we found that rucaparib potentiated the effects of all ruthenium complexes marked by a decrease in the $\mathrm{IC}_{50}$ values in combination treatment (Figure 10). Nevertheless, it is of note that the potentiation was not as marked as the effects of antioxidants; hence, PARP-mediated effects probably have minor importance. 
A
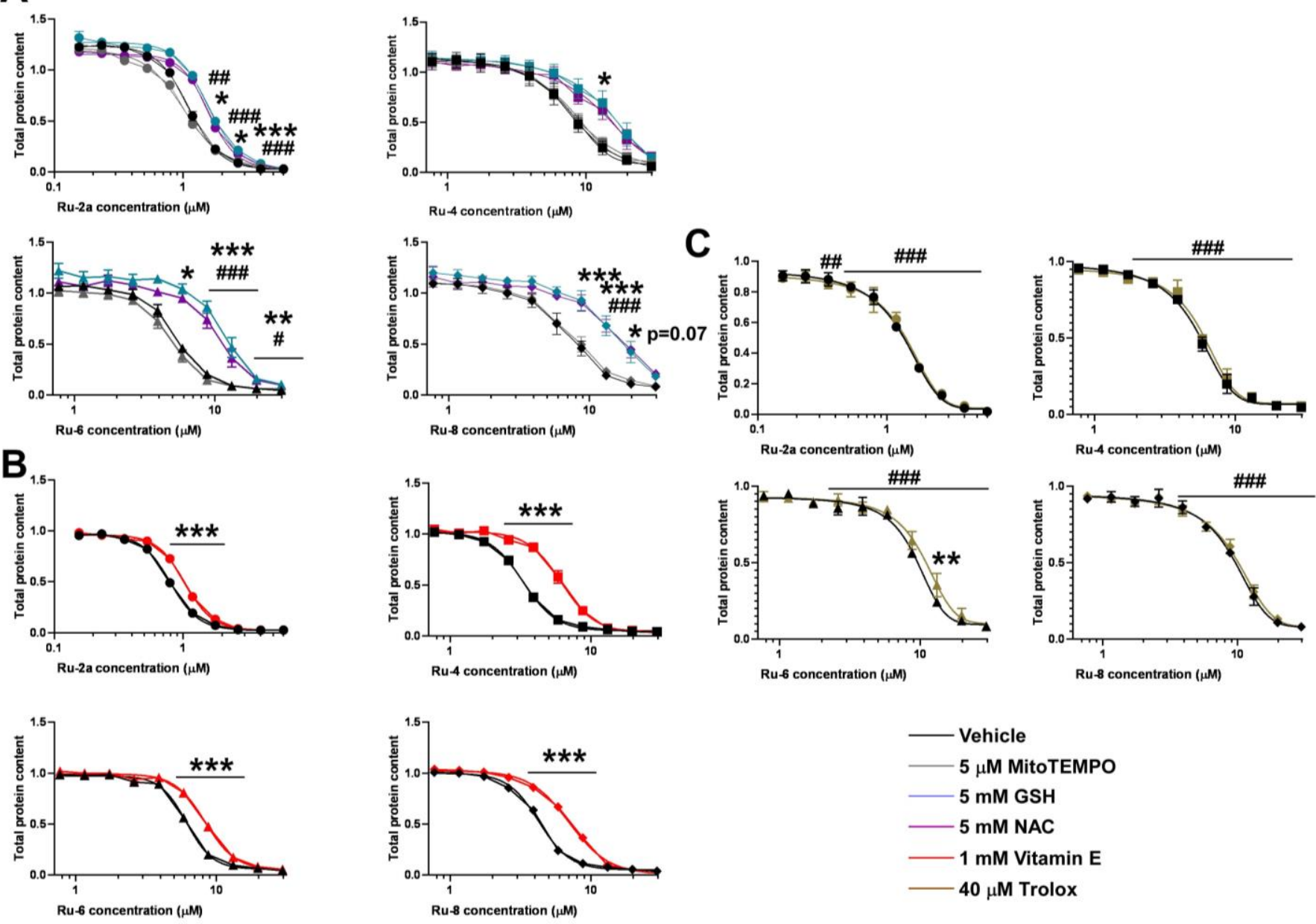

Figure 9. Reduced thiols and vitamin E can block the cytostatic effects of ruthenium complexes. (A) A total of $3 \times 10^{3} \mathrm{~A} 2780$ cells were plated on 96-well plates. Cells were treated with the reduced thiol compounds in the concentrations indicated for $48 \mathrm{~h}$, and then the SRB assay was performed. Data are presented as the average \pm SEM from three biological replicates. The individual SRB assays were performed in duplicate. Normality was tested; the Ru-4 dataset had a normal distribution, whereas Ru-2a, Ru-6, and Ru-8 dataset normality was achieved by logarithmic transformation. Statistical significance was determined using a two-way ANOVA test, and all measurement points were compared with each other. (B) A total of $3 \times 10^{3} \mathrm{~A} 2780$ cells were plated on 96-well plates. Cells were treated with the compounds in the concentrations indicated for $48 \mathrm{~h}$, and then the SRB assay was performed. Data are presented as the average \pm SEM from three biological replicates. The individual SRB assays were performed in duplicate. Normality was tested; the Ru-4 and Ru-8 datasets had a normal distribution, whereas Ru-2a and Ru-6 dataset normality was achieved by logarithmic transformation. (C) A total of $3 \times 10^{3}$ A2780 cells were plated on 96-well plates. Cells were treated with Trolox in the concentration indicated for $48 \mathrm{~h}$, and then the SRB assay was performed. Data are presented as the average \pm SEM from three biological replicates. The individual SRB assays were performed in duplicate. Normality was tested; the Ru-2a, Ru-6, and Ru-8 datasets had a normal distribution, whereas Ru-4 dataset normality was achieved by logarithmic transformation. Statistical significance was determined using a two-way ANOVA test, and all measurement points were compared with each other; ${ }^{*}, * *$, and ${ }^{* * *}$ indicate statistically significant differences between vehicle-treated (control) and antioxidant (GSH, NAC,

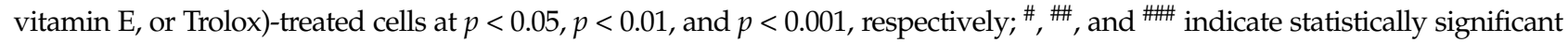
differences between vehicle-treated (control) and ruthenium-treated cells at $p<0.05, p<0.01$, and $p<0.001$, respectively. Values were normalized to vehicle-treated cells, where the absorbance of vehicle-treated cells was equal to 1. 

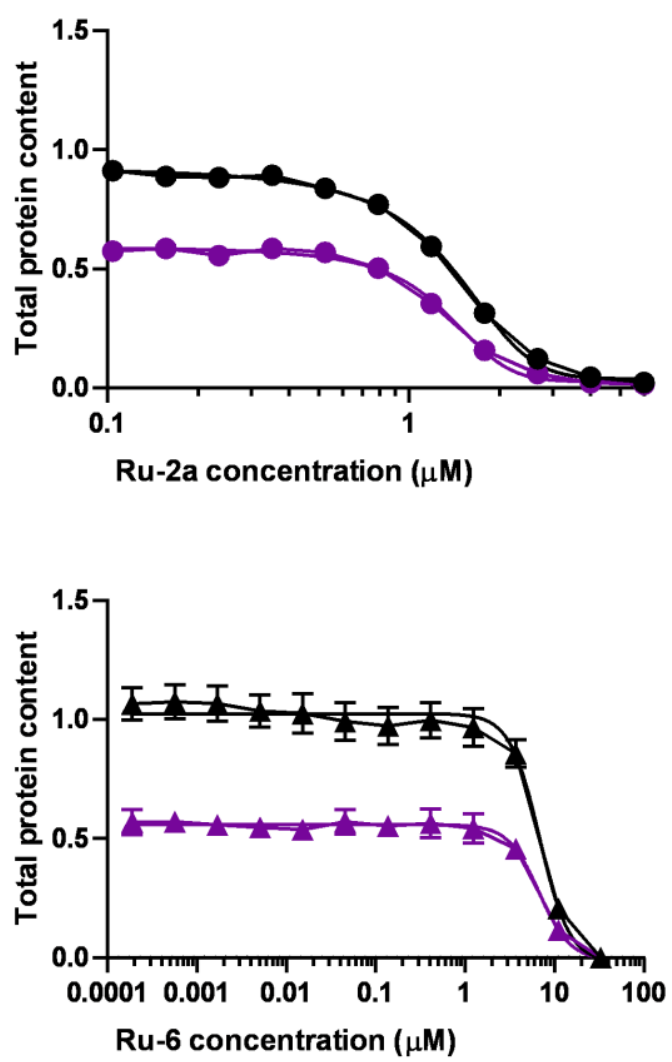
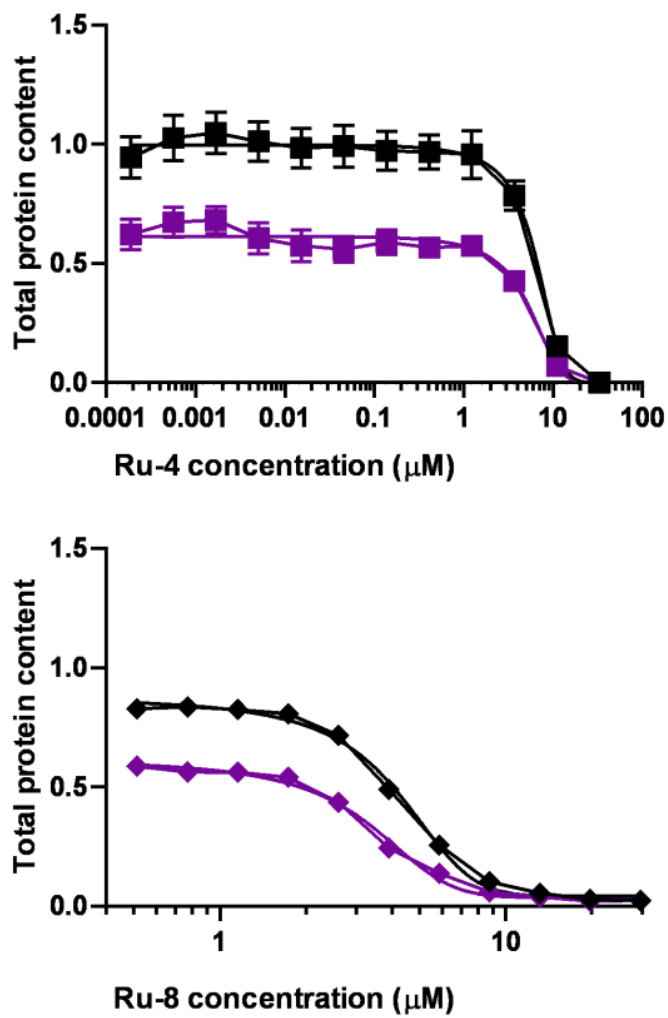

Ru-8 concentration $(\mu \mathrm{M})$
Vehicle

$3 \mu \mathrm{M}$ Rucaparib

\section{Ru-2a}

IC50 $_{\text {veh }}=1.382 \mu \mathrm{M}$

$\mathrm{IC} 0_{\text {Ruca }}=1.317 \mu \mathrm{M}$

Ru-4

$\mathrm{IC} \mathrm{voh}_{\text {veh }}=6.183 \mu \mathrm{M}$

$\mathrm{IC} 0_{\text {Ruca }}=4,52 \mu \mathrm{M}$

Ru-6

$\mathrm{IC} \mathrm{v}_{\mathrm{veh}}=6.827 \mu \mathrm{M}$

$\mathrm{IC} \mathrm{R}_{\text {Ruca }}=6.749 \mu \mathrm{M}$

Ru-8
IC50 $_{\text {veh }}=4.168 \mu \mathrm{M}$
IC50 $_{\text {Ruca }}=3.301 \mu \mathrm{M}$

Figure 10. Rucaparib potentiates the cytostatic effects of ruthenium complexes. A total of $3 \times 10^{3}$ A2780 cells were plated on 96-well plates. Cells were treated with rucaparib at $3 \mu \mathrm{M}$ concentration for $48 \mathrm{~h}$, and then the SRB assay was performed. Data are represented as the average $\pm \mathrm{SEM}$ from four biological replicates. Nonlinear regression was performed to obtain the $\mathrm{IC}_{50}$ values. Values were normalized to vehicle-treated cells, where the absorbance of vehicle-treated cells was equal to 1.

\subsection{Bioactive Ruthenium Complexes Can Cause Cytostasis in Breast Carcinoma, Pancreatic} Adenocarcinoma, and Glioblastoma Cell Lines

Prior studies [22,23,52,53] have suggested that sugar-based ruthenium complexes may be active on other cell lines and, therefore, potentially in other neoplastic diseases. We assessed breast cancer (modelled by MCF7 cells) as prior data [22] suggested the potential effectiveness of ruthenium complexes. Pancreatic adenocarcinoma (modelled by Capan2 cells) and glioblastoma (modelled by U251 cells), similar to ovarian cancer, are usually malign diseases where treatment options are limited [54-56]. All complexes exerted cytostatic effects on all cell lines in proliferation assays (SRB) (Figure 11). The $\mathrm{IC}_{50}$ values of the ruthenium complexes on U251, MCF7, and Capan2 were higher than on A2780 or ID8 cells (Table 3 ).

\subsection{The Carbohydrate Moiety Is Important for the Bioactivity of the Ruthenium Complexes}

To assess the role of the monosaccharide moiety in the bioactive compounds, we synthesized and assessed two molecules where the monosaccharide unit was substituted with a phenyl group (Ru-13/L-13 and $\mathbf{R u - 1 4 / L - 1 4 ) . ~ N e i t h e r ~ o f ~ t h e ~ f r e e ~ l i g a n d s , ~ L - 1 3 ~ o r ~ L - ~}$ 14, had cytostatic activity on A2780 cells in SRB assays (Figure 12). The triazole-containing Ru-13 was cytostatic on $\mathrm{A} 2780$ cells with an $\mathrm{IC}_{50}$ value of $\sim 12 \mu \mathrm{M}$, which was higher by one order of magnitude than the $\mathrm{IC}_{50}$ value of the sugar-containing molecule $\mathbf{R u}-\mathbf{2 a}$ (Figure 12, Table 3). Furthermore, the Hill coefficient of Ru-13 was 1.5, suggesting no or little cooperativity. The oxadiazole-containing Ru-14 had no cytostatic activity (Figure 12). 
U251

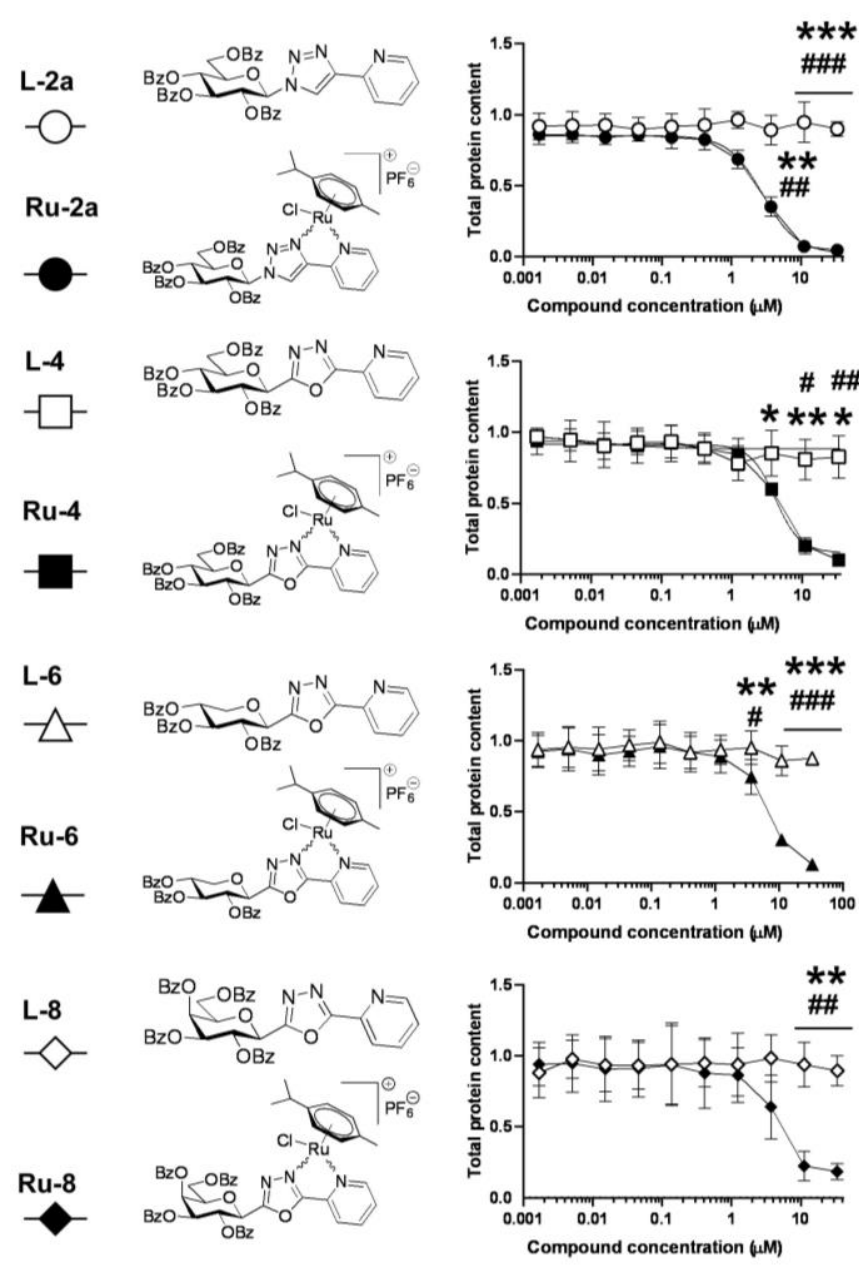

MCF7
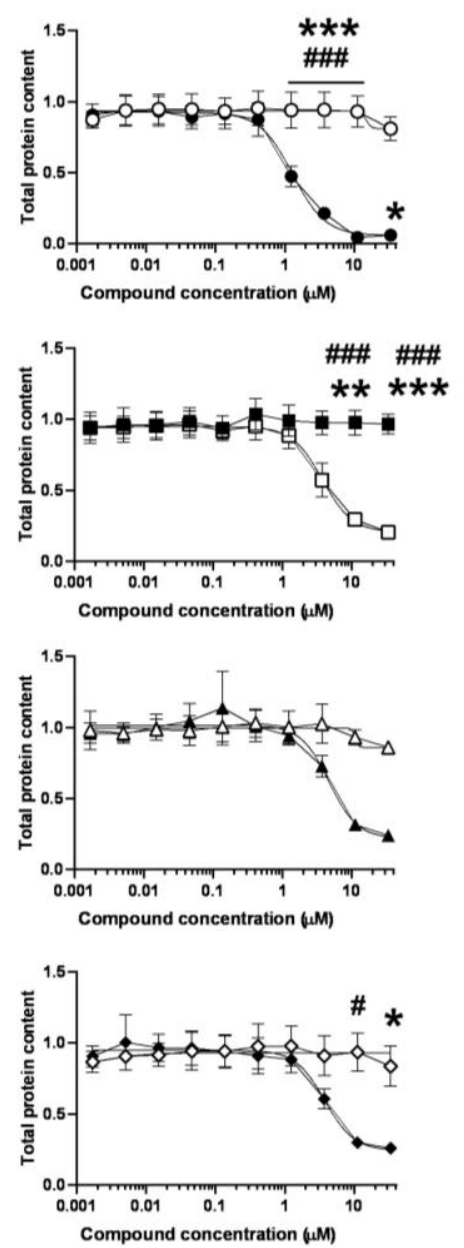

Capan2
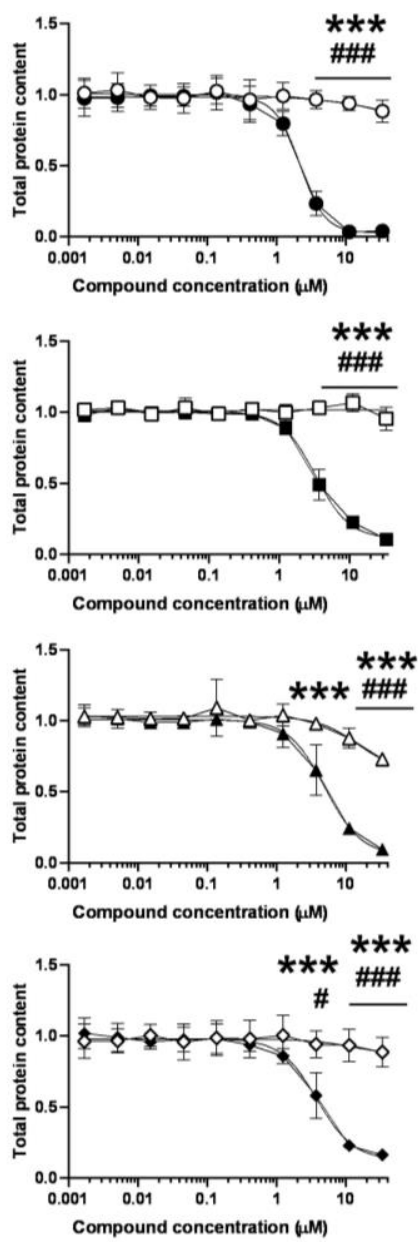

Figure 11. Assessment of the bioactive ruthenium complexes on models for glioblastoma, breast cancer, and pancreatic adenocarcinoma for cytostatic activity. A total of $2 \times 10^{3} \mathrm{U} 251$ cells (glioblastoma model), $3 \times 10^{3} \mathrm{MCF}$ cells (breast cancer), and $2 \times 10^{3}$ Capan2 (pancreatic adenocarcinoma) were plated on 96-well plates. Cells were treated with the compounds in the concentrations indicated for $48 \mathrm{~h}$, and then the SRB assay was performed. Data are presented as the average \pm SEM from three biological replicates; individual assays were performed in duplicate. Normality was tested; the Ru-4/L-4 U251, Ru-8/L8 U251, Ru-2a/L-2a U251, Ru-4/L-4 MCF7, Ru-8/L8 MCF7, Ru-4/L-4 Capan2, Ru-8/L8 Capan2, and Ru-2a/L-2a Capan2 datasets had a normal distribution, Ru-6/L-6 U251, Ru-2a/L-2a MCF7, and Ru-6/L-6 Capan2 dataset normality was achieved by logarithmic transformation, and the Ru-6/L-6 MCF7 dataset was normalized using the Box-Cox normalization method. Statistical significance was determined using a two-way ANOVA test, and all measurement points were compared with each other; ${ }^{*}$, ${ }^{* *}$, and ${ }^{* * *}$ indicate statistically significant differences between vehicle-treated (control) and free ligand/ruthenium complex-treated cells at $p<0.05$, $p<0.01$, and $p<0.001$, respectively; $\#, \#$, and $\# \#$ indicate statistically significant differences between free ligand-treated and ruthenium complex-treated cells at $p<0.05, p<0.01$, and $p<0.001$, respectively. Nonlinear regression was performed on the data. Values were normalized to vehicle-treated cells, where the absorbance of vehicle-treated cells was equal to 1. 

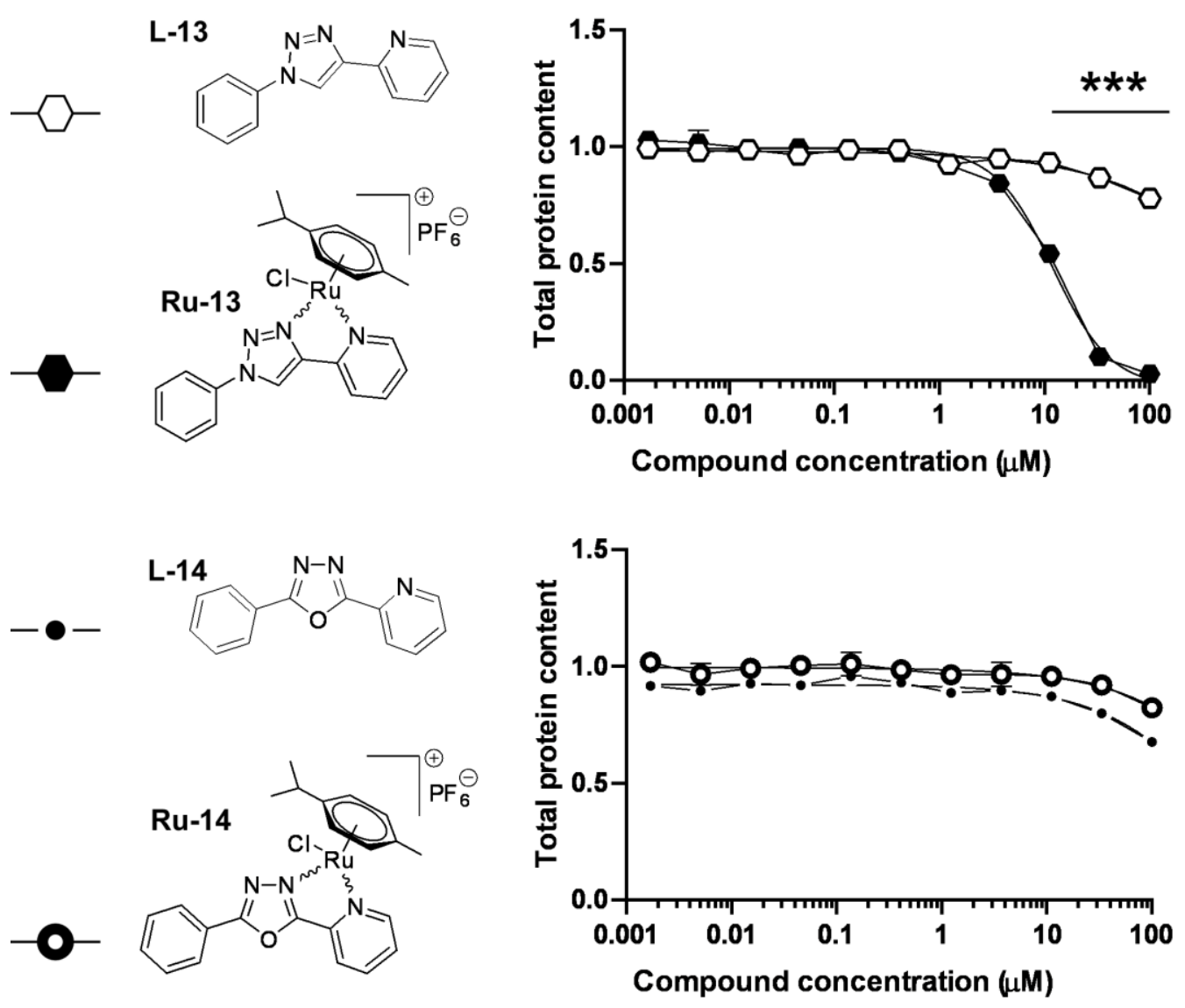

Figure 12. Assessment of non-sugar ruthenium complexes on A2780 cells for cytostatic activity. A total of $3 \times 10^{3}$ A2780 cells were plated on 96-well plates. Cells were treated with the compounds in the concentrations indicated for $48 \mathrm{~h}$, and then the SRB assay was performed. Data are represented as the average \pm SEM, from three biological replicates; individual assays were performed in duplicate. Normality was tested; both datasets were normalized using the Box-Cox normalization method. Statistical significance was determined using a two-way ANOVA test, and all measurement points were compared with each other; ${ }^{* * *}$ indicates statistically significant differences between vehicle-treated (control) and free ligand/ruthenium complex-treated cells at $p<0.001$. Nonlinear regression was performed on the data. Values were normalized to vehicle-treated cells, where the absorbance of vehicle-treated cells was equal to 1.

\section{Discussion}

In this study, we screened a set of carbohydrate-based half-sandwich type organoruthenium complexes. Four compounds were identified to display long-term cytostatic effects but little rapid toxicity on two different ovarian cancer cell lines. These compounds were not toxic toward primary human fibroblasts. The practical absence of toxicity on non-transformed fibroblasts aligns well with the low toxicity of other ruthenium complexes [9-12]. The activity of the compounds was dependent on the presence of ruthenium(II), as the ligands had no biological activity. The $\mathrm{IC}_{50}$ values of the active compounds were comparable or superior to the currently applied platinum compounds (cisplatin, oxaliplatin, and carboplatin) and other sugar-containing ruthenium complexes $[22,23,52,53]$. The identified $\mathrm{Ru}(\mathrm{II})$ compounds were active upon long-term application in SRB assays, similar to platinum compounds.

We assessed the relationship between the biological activity and the structure of the active molecules. We compared all complexes to Ru-4 that had considerable cytostatic potential in SRB assays on ovarian cancer cells but no activity on primary fibroblasts (Figure 13). An important structural feature that plays a key role in the biological activity of the molecules is the presence and size of the protecting groups on the hydroxyl groups of the carbohydrate moieties. All bioactive molecules (Ru-2a, Ru-4, Ru-6, and Ru-8) have $O$-benzoyl groups (Figure 13). Changing the $O$-benzoyl groups to smaller $O$-acetyl 
groups (Ru-4 vs. $\mathbf{R u} \mathbf{- 5})$ or complete deprotection ( $\mathbf{R u}-\mathbf{4}$ vs. $\mathbf{R u}-\mathbf{1 0})$ abrogated the inhibitory activity. These findings are similar to the observations of Hamala and colleagues [22], who showed that the inhibitory activity of carbohydrate-based ruthenium complexes (Figure 1, X) was enhanced when the hydroxyl groups of the sugar units were protected by esters. Furthermore, increasing the length of the acyl chain improved the inhibitory efficacy (acetyl < propionyl < butyryl). In good agreement with that, the replacement of the protected monosaccharide in the molecule with a single phenyl group lowered the cytostatic capacity of the ruthenium complex (Ru-13) or fully abrogated it (Ru-14). This finding also corroborates the inevitable role of the sugar moiety in determining the biological activity. Apparently, increasing the lipophilic character of the compounds improves the cytostatic properties of sugar-based ruthenium complexes. This is underlined by the $\log \mathrm{D}$ values in Tables 3 and S9 showing a significant difference in lipophilicity in favor of the benzoylated derivatives. Hanif and colleagues [52] also had similar findings with RAPTA analogs as a function of the size of the arene cap and the acetal protecting group. It is tempting to speculate that these large, apolar protective groups could facilitate the membrane permeability of these compounds. In good agreement with that, Trolox, a derivative of vitamin $\mathrm{E}$ that lacks the long apolar phytyl chain, was ineffective in protecting cells against cytostasis induced by ruthenium compounds. This finding suggests oxidative stress in apolar, lipid-containing compartments.
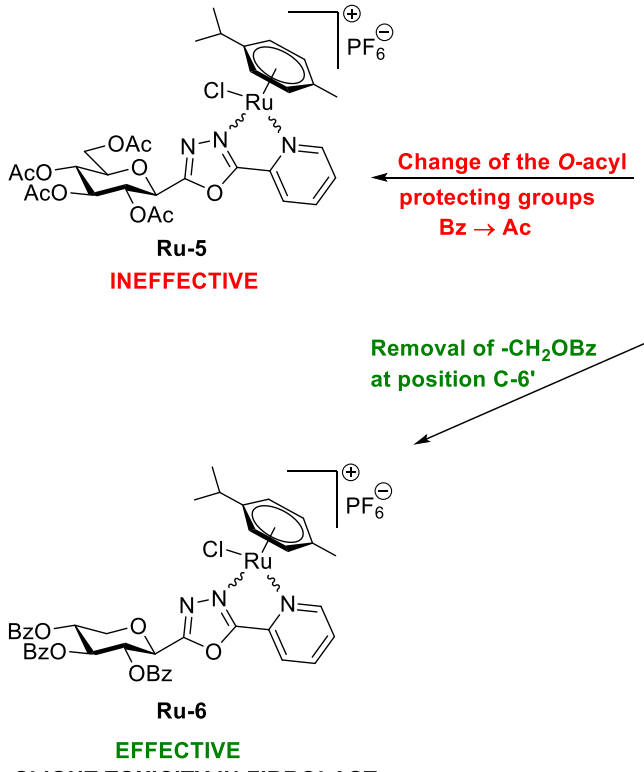

SLIGHT TOXICITY IN FIBROLAST
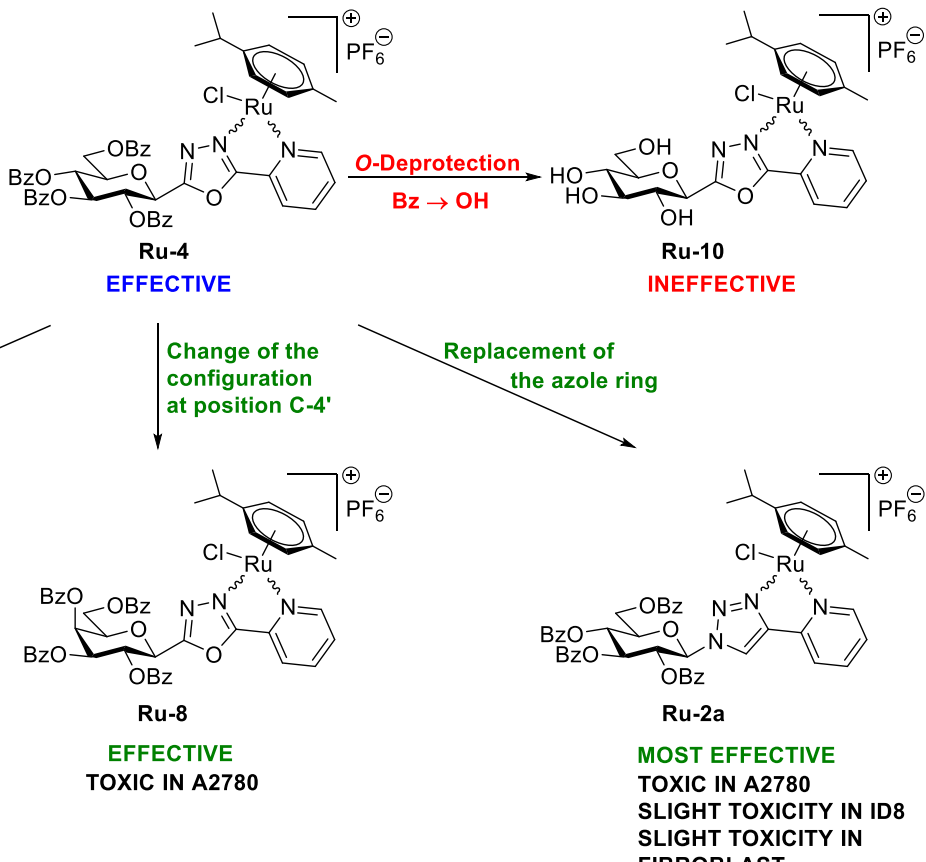

FIBROBLAST

Figure 13. Structure-function relationship assessment of the active compounds.

Furthermore, we found two other structural features that impacted bioactivity: (A) modification of the carbohydrate moiety from glucose to xylose by a formal removal of the hydroxymethyl group at position 5 (Ru-6) or changing the configuration of the C-4 center (glucose to galactose as in Ru-8), and (B) replacement of the 1,3,4-oxadiazole ring by 1,2,3-triazole (Ru-2a). These changes increased the rapid toxicity of the molecules or rendered the molecules toxic on primary cells (Figure 13). In addition, a triazole ring in the molecule ensured better cytostatic properties than an oxadiazole ring (Ru-13 vs. Ru-14 and $\mathbf{R u}-2 \mathbf{a}$ vs. $\mathbf{R u}-\mathbf{4})$.

It was a surprising observation that the binding of the active compounds showed a high level of cooperativity, as suggested by the value of the Hill slope, being 2-3 for Ru-2a, $\mathbf{R u}-\mathbf{4}, \mathbf{R u}-\mathbf{6}$, and $\mathbf{R u}-\mathbf{8}$. This suggests that the binding of a ruthenium complex facilitates the binding of the subsequent molecules. The Hill slope was also determined for the reference 
platinum-based drugs; however, these molecules did not show signs of cooperative binding as the Hill slope was $\sim 1$. Apparently, the binding and, probably, the mode of action of the ruthenium complexes identified in this study differ from those of the reference platinum compounds. In the study of Hanif et al. [52] assessing RAPTA analogs (general formula VIII in Figure 1), one compound was identified with a steep inhibitory curve, suggesting cooperative binding. This observation implicates that cooperative binding is not characteristic for all sugar-containing ruthenium complexes.

Our primary aim was to assess the applicability of ruthenium complexes in ovarian cancer, as these compounds were intended to be used as substitutes to platinum complexes [6]. Nevertheless, we provided evidence that the ruthenium complexes are also active in cell models of glioblastoma, breast cancer, and pancreatic adenocarcinoma, although the complexes showed preference toward ovarian cancer cells. Other sugar-containing ruthenium complexes were also active in ovarian cancer cell lines (A2780 [22,53], SK-OV3 [22], CH1 [52,53]) further underlying the applicability of such compounds in ovarian cancer. Nevertheless, Ru-sugar complexes showed a cytostatic response in MDA-MD-231 breast cancer cells [22], colon cancer [52,53], non-small-cell lung cancer [52], and cervical carcinoma (HeLa) cells [23], suggesting a wider applicability of such compounds.

Apparently, the mode of action of ruthenium complexes is pleiotropic and involves binding to polynucleotides [44] or the production of reactive oxygen species [9,15,41,42]. The actual mode of action or the dominant pathway to induce cytostasis differs for different classes of ruthenium complexes [15]. Carbohydrate-ruthenium complexes were shown to induce apoptosis that we did not detect for our compounds in concentrations corresponding to the $\mathrm{IC}_{50}$ values [22]. The active compounds identified in this study led to oxidative stress marked by increased 4HNE expression, a marker for lipid peroxidation. The functional role of reactive oxygen species production was confirmed by the application of GSH and NAC, two strong reductants, that reverted the cytostatic effects of the bioactive ruthenium complexes, as well as confirmed by using vitamin E. The source of reactive oxygen species was other than the mitochondria. Reactive oxygen species production was shown to be cytostatic in numerous carcinomas $[9,15,41,42,57]$. In addition to oxidative stress, we showed that the effects of ruthenium complexes is potentiated by a PARP inhibitor, rucaparib, similar to others $[41,42,49,50]$. Nevertheless, the level of potentiation was lower than the anticytostatic effects of antioxidants, pointing to a lower importance for PARP-mediated pathways.

\section{Conclusions}

In this work, 14 novel half-sandwich Ru(II) complexes with real glycosyl azole type bidentate ligands were synthesized. To this end, 4-(pyridin-2-yl)- and 4-(quinolin-2-yl)-1-( $\beta$ D-glucopyranosyl)-1,2,3-triazoles ( $N$-glycosyl derivatives) and 2-( $\beta$-D-glycosyl)-5-(pyridin2-yl)-1,3,4-oxadiazoles ( $C$-glycosyl derivatives) were prepared by 1,3-dipolar cycloaddition reactions. Treatment of these $N, N$-chelators with dichloro $\left(\eta^{6}-p\right.$-cymene)ruthenium(II) dimer $\left(\left[\left(\eta^{6}-p \text {-cym }\right) \mathrm{RuCl}_{2}\right]_{2}\right)$ in the presence of $\mathrm{TlPF}_{6}$ yielded the expected $\mathrm{Ru}(\mathrm{II})$-centered complexes with the general formula $\left[\left(\eta^{6}-p-c y m\right) \mathrm{Ru}^{\mathrm{II}}(\mathrm{N}-\mathrm{N}) \mathrm{Cl}\right] \mathrm{PF}_{6}$ as mixtures of diastereomers.

In the biological study of the complexes in ovarian adenocarcinoma cells, antineoplastic properties characterized by little acute toxicity but long-term cytostasis were identified. The bioactive ruthenium complexes had micromolar IC $_{50}$ values on A2780 and ID8 cells, while they had little or no activity on primary, non-transformed human fibroblasts, highlighting the low toxicity and selectivity of these compounds toward transformed cancer cells. The presence of the sugar moiety equipped with large hydrophobic protective groups on the hydroxyl groups of was found to be crucial for the biological activity. The bioactive ruthenium complexes, identified herein, showed cooperative binding to yet unidentified cellular target(s) and induced oxidative stress that was essential for their cytostatic activity. 


\section{Materials and Methods}

\subsection{Synthesis}

\subsubsection{General Methods}

Optical rotations were measured on a Jasco P-2000 polarimeter (Jasco, Easton, MD, USA) at r.t., and the data referred to the average of three parallel measurements. NMR spectra were recorded with DRX360 (360/90 MHz for $\left.{ }^{1} \mathrm{H} /{ }^{13} \mathrm{C}\right)$ or DRX400 (400/100 MHz for ${ }^{1} \mathrm{H} /{ }^{13} \mathrm{C}$ ) spectrometers (Bruker, Karlsruhe, Germany). Chemical shifts are referenced to $\mathrm{Me}_{4} \mathrm{Si}\left({ }^{1} \mathrm{H}-\mathrm{NMR}\right)$ or to the residual solvent signals $\left({ }^{13} \mathrm{C}-\mathrm{NMR}\right)$. Assigments of the proton and carbon signals of the new compounds were based on COSY and HSQC correlations. MS spectra were obtained using a Bruker maXis II (ESI-HRMS) spectrometer. TLC analysis were carried out by using DC Kieselgel $60 \mathrm{~F}_{254}$ plates (Sigma-Aldrich, Saint Louis, MO, USA), and the spots were visualized under UV light and by gentle heating. For column chromatographic purification, Kieselgel 60 (Molar Chemicals, Halásztelek, Hungary, particle size $0.063-0.2 \mathrm{~mm}$ ) silica gel was applied. Anhydrous solvents were obtained by using standard distillation procedures. Anhydrous $\mathrm{CH}_{2} \mathrm{Cl}_{2}, \mathrm{CHCl}_{3}$, and toluene were produced by distillation from $\mathrm{P}_{4} \mathrm{O}_{10}$ and then stored over $4 \AA$ molecular sieves $\left(\mathrm{CH}_{2} \mathrm{Cl}_{2}\right.$, $\mathrm{CHCl}_{3}$ ) or sodium wires (toluene). $\mathrm{MeOH}$ was dried by distillation over $\mathrm{Mg}$ turnings and iodine. The 2-ethynylpyridine (TCI Chemicals, Zwijndrecht, The Netherlands) and the dichloro $\left(\eta^{6}-p\right.$-cymene)ruthenium(II) dimer (Ru-dimer, Strem Chemicals, Newburyport, MA, USA) were purchased from the indicated suppliers. The 2,3,4,6-tetra- $O$-acetyl- $\beta$-Dglucopyranosyl-azide [28,29] (1), the 5-(2', $3^{\prime}, 4^{\prime}, 6^{\prime}$-tetra-O-benzoyl- $\beta$-D-glucopyranosyl)tetrazole [58,59] (2), the 5-(2', $3^{\prime}, 4^{\prime}$-tri-O-benzoyl- $\beta$-D-xylopyranosyl)-tetrazole [60] (3), the 5$\left(2^{\prime}, 3^{\prime}, 4^{\prime}, 6^{\prime}\right.$-tetra-O-acetyl- $\beta$-D-galactopyranosyl)-tetrazole [61] (4), the 2-(L-arabino- $1^{\prime}, 2^{\prime}, 3^{\prime}, 4^{\prime}$ tetraacetoxybutyl)-tetrazole [33] (5), the 2-ethynylquinoline [62], 1-phenyl-4-(pyridine-2yl)-1,2,3-triazole [34] (L-13), and the 2-phenyl-5-(pyridine-2-yl)-1,3,4-oxadiazole [35,36] (L-14) were synthesized according to procedures in the literature.

5.1.2. General Procedure I for the Preparation of $1-\left(2^{\prime}, 3^{\prime}, 4^{\prime}, 6^{\prime}\right.$-Tetra-O-acetyl- $\beta$-Dglucopyranosyl)-4-hetaryl-1,2,3-triazoles

To a solution of 1-(2,3,4,6-tetra-O-acetyl- $\beta$-D-glucopyranosyl)-azide [28,29] (1) in $\mathrm{CH}_{2} \mathrm{Cl}_{2}$ (1 mL/50 mg azide), the appropriate 2-ethynylated heterocycle (1 eq.) and the $\mathrm{C}_{3} \mathrm{H}_{7} \mathrm{COOCu}\left(\mathrm{PPh}_{3}\right)_{2}$ catalyst [30] (3 mol.\%) were added. The reaction mixture was stirred at r.t. for 1 day, and the completion of the reaction was judged by TLC (1:1 EtOAc-hexane). The solvent was then removed under diminished pressure, and the residue was purified by column chromatography.

5.1.3. General Procedure II for the Synthesis of O-Peracylated 2-glycosyl-5-(pyridin-2-yl)1,3,4-oxadiazoles

The corresponding $\mathrm{O}$-peracylated 5-glycosyl-tetrazole (2-5) was dissolved in dry toluene ( $1 \mathrm{~mL} / 100 \mathrm{mg}$ substrate), and then 2 -picolinic acid (2 eq.) and DCC (2 eq.) were added. The reaction mixture was stirred at boiling temperature until the TLC showed total consumption of the tetrazole. The insoluble materials were filtered off and washed with $\mathrm{CH}_{2} \mathrm{Cl}_{2}$, and the filtrate was evaporated under reduced pressure. The crude product was purified by column chromatography and crystallisation.

\subsubsection{General Procedure III for the Zemplén Deacylation}

An $\mathrm{O}$-acyl protected glycosyl-azole was dissolved in a 1:1 mixture of dry $\mathrm{MeOH}$ and dry $\mathrm{CHCl}_{3}(1 \mathrm{~mL} / 25 \mathrm{mg}$ substrate), and a few drops of a $\sim \mathrm{M}$ solution of $\mathrm{NaOMe}$ in $\mathrm{MeOH}$ was added ( $\mathrm{pH}=8-9)$. The reaction mixture was left at r.t. until the TLC indicated total conversion of the starting material. The neutralization of the solution was carried out by the addition of a cation exchange resin (Amberlyst $15, \mathrm{H}^{+}$form). The resin was then filtered off, and the solution was evaporated under reduced pressure. The crude product was purified by column chromatography or crystallization. 
5.1.5. General Procedure IV for the Formation of the $\left.\left[\left(\eta^{6}-\mathrm{p}-\mathrm{cym}\right) \mathrm{Ru}^{\mathrm{II}}(\mathrm{N}-\mathrm{N})\right) \mathrm{Cl}\right] \mathrm{PF}_{6}$ Type Complexes Containing O-peracylated Glycosyl Azole Ligands

To a solution of $\left(\left[\left(\eta^{6}-p \text {-cym }\right) \mathrm{RuCl}_{2}\right]_{2}\right)$ dimer (Ru-dimer) in $\mathrm{CH}_{2} \mathrm{Cl}_{2}(1 \mathrm{~mL} / 10 \mathrm{mg}$ dimer), the corresponding $O$-peracylated glycosyl azole (2-2.3 eq.) and $\mathrm{TlPF}_{6}(2$ eq.) were added. Under stirring, $1 \mathrm{~mL}$ of methanol was added to this reaction mixture in order to accelerate the precipitation of the $\mathrm{TlCl}$. The initial red solution turned to yellow, indicating the formation of the $\left[\left(\eta^{6}-p-c y m\right) \mathrm{Ru}^{\mathrm{II}}(\mathrm{N}-\mathrm{N}) \mathrm{Cl}\right] \mathrm{PF}_{6}$ type complex. The reaction mixture was then stirred at r.t. for an additional hour, and the total disappearance of the Ru-dimer was judged by TLC (9:1 $\left.\mathrm{CHCl}_{3}-\mathrm{MeOH}\right)$. After completion of the complexation reaction, the precipitated $\mathrm{TlCl}$ was filtered off, and the solution was evaporated in vacuo. The crude complex was purified by column chromatography or crystallization.

5.1.6. General Procedure $V$ for the Formation of the $\left[\left(\eta^{6}-p-c y m\right) \mathrm{Ru}^{\mathrm{II}}(\mathrm{N}-\mathrm{N}) \mathrm{Cl}\right] \mathrm{PF}_{6}$ Type Complexes Containing Unprotected Glycosyl Azole Ligands

In a solution of $\left(\left[\left(\eta^{6}-p-c y m\right) \mathrm{RuCl}_{2}\right]_{2}\right)$ dimer (Ru-dimer) in $\mathrm{CH}_{2} \mathrm{Cl}_{2}(1 \mathrm{~mL} / 10 \mathrm{mg}$ dimer), the corresponding unprotected glycosyl azole (2 eq.) and $\mathrm{TlPF}_{6}(2$ eq.) were suspended. Under stirring, $1 \mathrm{~mL}$ of methanol was added to this reaction mixture in order to dissolve the heterocyclic sugar derivative and accelerate the precipitation of the $\mathrm{TlCl}$. The initial red solution turned to yellow, indicating the formation of the $\left[\left(\eta^{6}-p-c y m\right) \mathrm{Ru}^{\mathrm{II}}(\mathrm{N}-\right.$ $\mathrm{N}) \mathrm{Cl}] \mathrm{PF}_{6}$ type complex. The reaction mixture was then stirred at r.t. for an additional hour, and the total disappearance of the Ru-dimer was judged by TLC $\left(9: 1 \mathrm{CHCl}_{3}-\mathrm{MeOH}\right)$. After completion of the complexation reaction, the precipitated $\mathrm{TlCl}$ was filtered off, and the solution was evaporated in vacuo. The crude complex was purified by crystallization.

\subsubsection{1-(2', $3^{\prime}, 4^{\prime}, 6^{\prime}$-Tetra-O-acetyl- $\beta$-D-glucopyranosyl)-4-(pyridin-2-yl)-1,2,3-triazole (L-1a)}

Prepared from azide [28,29] $1(100 \mathrm{mg}, 0.27 \mathrm{mmol})$ and 2-ethynylpyridine $(28 \mu \mathrm{L}, 0.27 \mathrm{mmol})$ according to general procedure I. Purified by column chromatography $(1: 1 \rightarrow 2: 1$ EtOAchexane) to give $121 \mathrm{mg}$ white amorphous solid $(95 \%) . \mathrm{R}_{\mathrm{f}}=0.18$ (1:1 EtOAc-hexane); $[\alpha]_{\mathrm{D}}=-55\left(\mathrm{c} 0.21, \mathrm{CHCl}_{3}\right) .{ }^{1} \mathrm{H}-\mathrm{NMR}\left(360 \mathrm{MHz}, \mathrm{CDCl}_{3}\right) \delta(\mathrm{ppm}): 8.61(1 \mathrm{H}, \mathrm{d}, J=4.8 \mathrm{~Hz}$, Py-H-6), $8.42(1 \mathrm{H}, \mathrm{s}$, Tria-H-5), $8.15(1 \mathrm{H}, \mathrm{d}, J=7.8 \mathrm{~Hz}, \mathrm{Py}-\mathrm{H}-3), 7.78(1 \mathrm{H}, \mathrm{dt}, J=7.8,1.6 \mathrm{~Hz}$, Py-H-4), $7.25(1 \mathrm{H}, \mathrm{m}, \mathrm{Py}-\mathrm{H}-5), 5.94\left(1 \mathrm{H}, \mathrm{d}, J=8.8 \mathrm{~Hz}, \mathrm{H}-1^{\prime}\right), 5.51(1 \mathrm{H}, \mathrm{pt}, J=9.5,9.5 \mathrm{~Hz}$, $\left.\mathrm{H}-2^{\prime}\right), 5.46\left(1 \mathrm{H}, \mathrm{pt}, J=9.5,9.5 \mathrm{~Hz}, \mathrm{H}-3^{\prime}\right), 5.28\left(1 \mathrm{H}, \mathrm{pt}, J=9.5,9.5 \mathrm{~Hz}, \mathrm{H}-4^{\prime}\right), 4.32(1 \mathrm{H}, \mathrm{dd}$, $\left.J=12.6,4.8 \mathrm{~Hz}, \mathrm{H}-6^{\prime} \mathrm{a}\right), 4.17\left(1 \mathrm{H}, \mathrm{dd}, J=12.6,1.7 \mathrm{~Hz}, \mathrm{H}-6^{\prime} \mathrm{b}\right), 4.04(1 \mathrm{H}, \mathrm{ddd}, J=9.5,4.8$, $\left.1.7 \mathrm{~Hz}, \mathrm{H}-5^{\prime}\right), 2.10,2.08,2.05,1.90\left(4 \times 3 \mathrm{H}, 4 \mathrm{~s}, 4 \times \mathrm{CH}_{3}\right) ;{ }^{13} \mathrm{C}-\mathrm{NMR}\left(90 \mathrm{MHz}, \mathrm{CDCl}_{3}\right) \delta$ (ppm): 170.6, 170.1, 169.4, $168.9(4 \times \mathrm{C}=\mathrm{O}), 149.8,149.2$ (Tria-C-4, Py-C-2), 149.7 (Py-C-6), 137.0 (Py-C-4), 123.3 (Py-C-5), 120.5 (Py-C-3), 120.7 (Tria-C-5), 86.0 (C-1'), 75.3 (C-5'), 72.8 $\left(\mathrm{C}-3^{\prime}\right), 70.7\left(\mathrm{C}-2^{\prime}\right), 67.8\left(\mathrm{C}-4^{\prime}\right), 61.7\left(\mathrm{C}-6^{\prime}\right), 20.8,20.7(2), 20.3\left(4 \times \mathrm{CH}_{3}\right)$. The ${ }^{1} \mathrm{H}$ and ${ }^{13} \mathrm{C}$ NMR data are in good agreement with the reported ones [63]. ESI-HRMS positive mode $(\mathrm{m} / \mathrm{z})$ : calculated for $\mathrm{C}_{21} \mathrm{H}_{25} \mathrm{~N}_{4} \mathrm{O}_{9}{ }^{+}[\mathrm{M}+\mathrm{H}]^{+} 477.1616 ; \mathrm{C}_{21} \mathrm{H}_{24} \mathrm{~N}_{4} \mathrm{NaO}_{9}{ }^{+}[\mathrm{M}+\mathrm{Na}]^{+} 499.1435$. Found: $[\mathrm{M}+\mathrm{H}]^{+}$477.1614; $[\mathrm{M}+\mathrm{Na}]^{+} 499.1432$.

5.1.8. 1-(2', $3^{\prime}, 4^{\prime}, 6^{\prime}$-Tetra-O-acetyl- $\beta$-D-glucopyranosyl)-4-(quinolin-2-yl)-1,2,3-triazole (L-1b)

Prepared from azide [28,29] $1(1.00 \mathrm{~g}, 2.68 \mathrm{mmol})$ and 2-ethynylquinoline [62] $(0.41 \mathrm{~g}, 2.68 \mathrm{mmol})$ according to general procedure I. Purified by column chromatography (1:1 EtOAc-hexane) to yield $1.20 \mathrm{~g}$ white amorphous solid $(85 \%) . R_{f}=0.23(1: 1$ EtOAc-hexane); $[\alpha]_{\mathrm{D}}=-90$ (c 0.20, $\left.\mathrm{CHCl}_{3}\right) .{ }^{1} \mathrm{H}-\mathrm{NMR}\left(360 \mathrm{MHz}, \mathrm{CDCl}_{3}\right) \delta(\mathrm{ppm}): 8.63$ $(1 \mathrm{H}, \mathrm{s}$, Tria-H-5), $8.31(1 \mathrm{H}, \mathrm{d}, J=8.6 \mathrm{~Hz}, \mathrm{Qu}-\mathrm{H}-3), 8.24(1 \mathrm{H}, \mathrm{d}, J=8.6 \mathrm{~Hz}, \mathrm{Qu}-\mathrm{H}-4), 8.08(1 \mathrm{H}$, $\mathrm{d}, J=8.5 \mathrm{~Hz}, \mathrm{Qu}-\mathrm{H}-5$ or Qu-H-8), $7.82(1 \mathrm{H}, \mathrm{d}, J=8.0 \mathrm{~Hz}, \mathrm{Qu}-\mathrm{H}-5$ or Qu-H-8), $7.72(1 \mathrm{H}, \mathrm{pt}$, $J=7.9,7.6 \mathrm{~Hz}, \mathrm{Qu}-\mathrm{H}-6$ or Qu-H-7), $7.53(1 \mathrm{H}, \mathrm{pt}, J=7.5,7.4 \mathrm{~Hz}$, Qu-H-6 or Qu-H-7), 5.99 $\left(1 \mathrm{H}, \mathrm{d}, J=9.2 \mathrm{~Hz}, \mathrm{H}-1^{\prime}\right), 5.59\left(1 \mathrm{H}, \mathrm{pt}, J=9.4,9.2 \mathrm{~Hz}, \mathrm{H}-2^{\prime}\right), 5.48\left(1 \mathrm{H}, \mathrm{pt}, J=9.5,9.4 \mathrm{~Hz}, \mathrm{H}-3^{\prime}\right)$, $5.31\left(1 \mathrm{H}, \mathrm{pt}, J=9.7,9.5 \mathrm{~Hz}, \mathrm{H}-4^{\prime}\right), 4.35\left(1 \mathrm{H}, \mathrm{dd}, J=12.6,4.8 \mathrm{~Hz}, \mathrm{H}-6^{\prime} \mathrm{a}\right), 4.18(1 \mathrm{H}, \mathrm{dd}, J=12.6$, $\left.2.1 \mathrm{~Hz}, \mathrm{H}-6^{\prime} \mathrm{b}\right), 4.07\left(1 \mathrm{H}, \mathrm{ddd}, J=9.7,4.8,2.1 \mathrm{~Hz}, \mathrm{H}-5^{\prime}\right), 2.11,2.09,2.05,1.91(4 \times 3 \mathrm{H}, 4 \mathrm{~s}$, $\left.4 \times \mathrm{CH}_{3}\right) ;{ }^{13} \mathrm{C}-\mathrm{NMR}\left(90 \mathrm{MHz}, \mathrm{CDCl}_{3}\right) \delta(\mathrm{ppm}): 170.6,170.1,169.4,169.0(4 \times \mathrm{C}=\mathrm{O}), 149.8$, 
149.4, 148.2 (Tria-C-4, Qu-C-2, Qu-C-8a), 137.0 (Qu-C-4), 129.9 (Qu-C-6 or Qu-C-7), 129.3 (Qu-C-5 or Qu-C-8), 128.0 (Qu-C-4a), 127.8 (Qu-C-5 or Qu-C-8), $126.6(\mathrm{Qu}-\mathrm{C}-6$ or Qu-C-7), 121.4 (Tria-C-5), 118.7 (Qu-C-3), $86.0\left(\mathrm{C}-1^{\prime}\right), 75.3\left(\mathrm{C}-5^{\prime}\right), 72.9\left(\mathrm{C}-3^{\prime}\right), 70.7\left(\mathrm{C}-2^{\prime}\right), 67.8\left(\mathrm{C}-4^{\prime}\right)$, $61.7\left(\mathrm{C}-6^{\prime}\right), 20.8,20.6(2), 20.3\left(4 \times \mathrm{CH}_{3}\right)$. The ${ }^{1} \mathrm{H}$ and ${ }^{13} \mathrm{C}$ NMR data are in good agreement with the reported ones [64]. ESI-HRMS positive mode $(\mathrm{m} / \mathrm{z})$ : calculated for $\mathrm{C}_{25} \mathrm{H}_{27} \mathrm{~N}_{4} \mathrm{O}_{9}{ }^{+}$ $[\mathrm{M}+\mathrm{H}]^{+}$527.1773; $\mathrm{C}_{25} \mathrm{H}_{26} \mathrm{~N}_{4} \mathrm{NaO}_{9}{ }^{+}[\mathrm{M}+\mathrm{Na}]^{+}$549.1592. Found: $[\mathrm{M}+\mathrm{H}]^{+}$527.1773; $[\mathrm{M}+\mathrm{Na}]^{+} 549.1593$.

5.1.9. 1-( $2^{\prime}, 3^{\prime}, 4^{\prime}, 6^{\prime}$-Tetra-O-benzoyl- $\beta$-D-glucopyranosyl)-4-(pyridin-2-yl)-1,2,3-triazole (L-2a)

The 1-( $\beta$-D-glucopyranosyl)-4-(pyridin-2-yl)-1,2,3-triazole (L-3a, $20.0 \mathrm{mg}, 0.065 \mathrm{mmol})$ was suspended in dry pyridine $(0.5 \mathrm{~mL})$, and benzoyl chloride $(36 \mu \mathrm{L}, 0.310 \mathrm{mmol})$ was added. The reaction mixture was stirred at $60^{\circ} \mathrm{C}$ until the TLC (3:2 EtOAc-hexane) showed complete disappearance of the starting material $(1 \mathrm{~h})$. The solvent was removed under diminished pressure. The residue was dissolved in $\mathrm{CH}_{2} \mathrm{Cl}_{2}(20 \mathrm{~mL})$ and extracted with sat. aq. $\mathrm{NaHCO}_{3}(10 \mathrm{~mL})$ and then with water $(10 \mathrm{~mL})$. The organic phase was dried over $\mathrm{MgSO}_{4}$, filtered, and evaporated. Purification by column chromatography (3:2 EtOAchexane) yielded $41 \mathrm{mg}$ of white amorphous solid $(87 \%) . \mathrm{R}_{\mathrm{f}}=0.30$ (3:2 EtOAc-hexane); $[\alpha]_{\mathrm{D}}=-75\left(\mathrm{c} 0.20, \mathrm{CHCl}_{3}\right) .{ }^{1} \mathrm{H}-\mathrm{NMR}\left(400 \mathrm{MHz}, \mathrm{CDCl}_{3}\right) \delta(\mathrm{ppm}): 8.61(2 \mathrm{H}, 1$ signal, Tria-H5, Py-H-6), 8.17-7.21 (23H, m, Ar, Py-H-3-Py-H-5), $6.34\left(1 \mathrm{H}, \mathrm{d}, J=9.2 \mathrm{~Hz}, \mathrm{H}-1^{\prime}\right), 6.16(1 \mathrm{H}$, pt, $\left.J=9.6,9.5 \mathrm{~Hz}, \mathrm{H}-3^{\prime}\right) 6.07\left(1 \mathrm{H}, \mathrm{pt}, J=9.5,9.2 \mathrm{~Hz}, \mathrm{H}-2^{\prime}\right), 5.90\left(1 \mathrm{H}, \mathrm{pt}, J=9.6,9.6 \mathrm{~Hz}, \mathrm{H}-4^{\prime}\right)$, 4.69-4.49 (3H, m, H-5' , H-6'a, H-6'b); ${ }^{13} \mathrm{C}-\mathrm{NMR}$ (100 MHz, $\left.\mathrm{CDCl}_{3}\right) \delta$ (ppm): 166.2, 165.8, 165.2, 164.7 (4 × C=O), 149.7, 149.0 (Tria-C-4, Py-C-2), 149.6 (Py-C-6), 137.1 (Py-C-4), 133.8, 133.7, 133.6, 133.5, 133.4, 130.2-128.2 (Ar), 123.3 (Py-C-5), 121.0 (Tria-C-5), 120.6 (Py-C-3), $86.4\left(\mathrm{C}-1^{\prime}\right), 75.7\left(\mathrm{C}-5^{\prime}\right), 73.2\left(\mathrm{C}-3^{\prime}\right), 71.3\left(\mathrm{C}-2^{\prime}\right), 69.0\left(\mathrm{C}-4^{\prime}\right), 62.8\left(\mathrm{C}-6^{\prime}\right)$. ESI-HRMS positive mode $(m / z)$ : calculated for $\mathrm{C}_{41} \mathrm{H}_{32} \mathrm{~N}_{4} \mathrm{NaO}_{9}{ }^{+}[\mathrm{M}+\mathrm{Na}]^{+}$747.2061. Found: 747.2041.

\subsubsection{1-( 3 -D-Glucopyranosyl)-4-(pyridin-2-yl)-1,2,3-triazole (L-3a)}

Prepared from compound L-1a $(0.81 \mathrm{~g}, 1.70 \mathrm{mmol})$ according to general procedure III. Purified by column chromatography $\left(7: 2 \mathrm{CHCl}_{3}-\mathrm{MeOH}\right)$ to give $0.40 \mathrm{~g}$ white amorphous solid $(76 \%) . \mathrm{R}_{\mathrm{f}}=0.26\left(7: 2 \mathrm{CHCl}_{3}-\mathrm{MeOH}\right) ;[\alpha]_{\mathrm{D}}=-12($ c $0.20, \mathrm{MeOH}) .{ }^{1} \mathrm{H}-\mathrm{NMR}(400 \mathrm{MHz}$, $\left.\mathrm{CD}_{3} \mathrm{OD}\right) \delta(\mathrm{ppm}): 8.63(1 \mathrm{H}, \mathrm{s}$, Tria-H-5), $8.59(1 \mathrm{H}, \mathrm{d}, J=4.3 \mathrm{~Hz}, \mathrm{Py}-\mathrm{H}-6), 8.09(1 \mathrm{H}, \mathrm{d}$, $J=7.9$ Hz, Py-H-3), 7.92 (1H, pt, $J=7.9,7.8$ Hz, Py-H-4), 7.38 (1H, m, Py-H-5), 5.70 (1H, d, $\left.J=9.2 \mathrm{~Hz},{\mathrm{H}-1^{\prime}}^{\prime}\right), 3.96\left(1 \mathrm{H}, \mathrm{pt}, J=9.1,9.0 \mathrm{~Hz}, \mathrm{H}-2^{\prime}\right), 3.90\left(1 \mathrm{H}, \mathrm{dd}, J=12.2,1.3 \mathrm{~Hz}, \mathrm{H}-6^{\prime} \mathrm{a}\right), 3.74$ $\left(1 \mathrm{H}, \mathrm{dd}, J=12.2,5.3 \mathrm{~Hz}, \mathrm{H}-6^{\prime} \mathrm{b}\right), 3.64-3.58\left(2 \mathrm{H}, \mathrm{m}, \mathrm{H}-3^{\prime}\right.$ or $\left.\mathrm{H}-4^{\prime}, \mathrm{H}-5^{\prime}\right), 3.54(1 \mathrm{H}, \mathrm{pt}, J=9.2$, $9.1 \mathrm{~Hz}, \mathrm{H}-3^{\prime}$ or H-4'); ${ }^{13} \mathrm{C}-\mathrm{NMR}\left(90 \mathrm{MHz}, \mathrm{CD}_{3} \mathrm{OD}\right) \delta$ (ppm): 150.9, 148.6 (Tria-C-4, Py-C-2), 150.5 (Py-C-6), 138.9 (Py-C-4), 124.6 (Py-C-5), 123.4 (Tria-C-5), 121.7 (Py-C-3), 89.8 (C-1'), $81.2\left(\mathrm{C}-5^{\prime}\right), 78.5\left(\mathrm{C}-3^{\prime}\right.$ or $\left.\mathrm{C}-4^{\prime}\right), 74.1\left(\mathrm{C}-2^{\prime}\right), 70.9\left(\mathrm{C}-3^{\prime}\right.$ or $\left.\mathrm{C}-4^{\prime}\right), 62.4\left(\mathrm{C}-6^{\prime}\right)$. The ${ }^{1} \mathrm{H}$ and ${ }^{13} \mathrm{C}$ $\mathrm{NMR}$ data are in good agreement with the reported ones [65]. ESI-HRMS positive mode $(m / z)$ : calculated for $\mathrm{C}_{13} \mathrm{H}_{16} \mathrm{~N}_{4} \mathrm{NaO}_{5}{ }^{+}[\mathrm{M}+\mathrm{Na}]^{+} 331.1013 ; \mathrm{C}_{26} \mathrm{H}_{32} \mathrm{~N}_{8} \mathrm{NaO}_{10}{ }^{+}[2 \mathrm{M}+\mathrm{Na}]^{+}$ 639.2134. Found: $[\mathrm{M}+\mathrm{Na}]^{+} 331.1012 ;[2 \mathrm{M}+\mathrm{Na}]^{+} 639.2135$.

\subsubsection{1-( $\beta$-D-Glucopyranosyl)-4-(quinolin-2-yl)-1,2,3-triazole (L-3b)}

Prepared from compound $\mathbf{L - 1 b}(500 \mathrm{mg}, 0.95 \mathrm{mmol})$ according to general procedure III. The crude product was recrystallized from $\mathrm{MeOH}$ to yield $290 \mathrm{mg}$ of white amorphous solid $(85 \%) . \mathrm{R}_{\mathrm{f}}=0.44\left(7: 2 \mathrm{CHCl}_{3}-\mathrm{MeOH}\right) ;[\alpha]_{\mathrm{D}}=-4$ (c 0.20, DMSO). ${ }^{1} \mathrm{H}-\mathrm{NMR}(400 \mathrm{MHz}$, DMSO- $d_{6}+1-2$ drops of $\left.\mathrm{D}_{2} \mathrm{O}\right) \delta(\mathrm{ppm}): 8.99(1 \mathrm{H}, \mathrm{s}$, Tria-H-5), $8.51(1 \mathrm{H}, \mathrm{d}, J=8.6 \mathrm{~Hz}$, Qu-H-4), $8.25(1 \mathrm{H}, \mathrm{d}, J=8.6 \mathrm{~Hz}, \mathrm{Qu}-\mathrm{H}-3), 8.06-8.01(2 \mathrm{H}, \mathrm{m}, \mathrm{Qu}-\mathrm{H}-5, \mathrm{Qu}-\mathrm{H}-8), 7.82$ (1H, pt, $J=7.8,7.4 \mathrm{~Hz}, \mathrm{Qu}-\mathrm{H}-6$ or Qu-H-7), $7.63(1 \mathrm{H}, \mathrm{pt}, J=7.6,7.4 \mathrm{~Hz}, \mathrm{Qu}-\mathrm{H}-6$ or Qu-H-7), $5.68(1 \mathrm{H}$, $\left.\mathrm{d}, J=9.2 \mathrm{~Hz}, \mathrm{H}-1^{\prime}\right), 3.90\left(1 \mathrm{H}, \mathrm{pt}, J=9.2,9.1 \mathrm{~Hz}, \mathrm{H}-2^{\prime}\right), 3.77-3.72\left(1 \mathrm{H}, \mathrm{m}, \mathrm{H}-6^{\prime} \mathrm{a}\right), 3.56-3.49$ $\left(2 \mathrm{H}, \mathrm{m}, \mathrm{H}-5^{\prime}, \mathrm{H}-6^{\prime} \mathrm{b}\right), 3.46\left(1 \mathrm{H}, \mathrm{pt}, J=9.1,9.0 \mathrm{~Hz}, \mathrm{H}-3^{\prime}\right), 3.34\left(1 \mathrm{H}, \mathrm{pt}, J=9.2,9.0 \mathrm{~Hz}, \mathrm{H}-4^{\prime}\right)$; ${ }^{13} \mathrm{C}-\mathrm{NMR}\left(90 \mathrm{MHz}, \mathrm{DMSO}-d_{6}\right) \delta$ (ppm): 150.1, 147.5, 147.3 (Tria-C-4, Qu-C-2, Qu-C-8a), 137.3 (Qu-C-4), 130.1 (Qu-C-6 or Qu-C-7), 128.6, 128.1 (Qu-C-5, Qu-C-8), 127.3 (Qu-C-4a), 126.5 (Qu-C-6 or Qu-C-7) 123.3 (Tria-C-5), $118.3(\mathrm{Qu}-\mathrm{C}-3), 87.8\left(\mathrm{C}-1^{\prime}\right), 80.0\left(\mathrm{C}-5^{\prime}\right), 76.8$ $\left(\mathrm{C}-3^{\prime}\right), 72.2\left(\mathrm{C}-2^{\prime}\right), 69.5\left(\mathrm{C}-4^{\prime}\right), 60.8\left(\mathrm{C}-6^{\prime}\right)$. ESI-HRMS positive mode $(\mathrm{m} / z)$ : calculated for 
$\mathrm{C}_{17} \mathrm{H}_{19} \mathrm{~N}_{4} \mathrm{O}_{5}{ }^{+}[\mathrm{M}+\mathrm{H}]^{+}$359.1350; $\mathrm{C}_{17} \mathrm{H}_{18} \mathrm{~N}_{4} \mathrm{NaO}_{5}{ }^{+}[\mathrm{M}+\mathrm{Na}]^{+} 381.1169 ; \mathrm{C}_{34} \mathrm{H}_{36} \mathrm{~N}_{8} \mathrm{NaO}_{10}{ }^{+}$ $[2 \mathrm{M}+\mathrm{Na}]^{+}$739.2447. Found: $[\mathrm{M}+\mathrm{H}]^{+}$359.1349; $[\mathrm{M}+\mathrm{Na}]^{+}$381.1168; $[2 \mathrm{M}+\mathrm{Na}]^{+} 739.2448$.

5.1.12. 2-(2', $3^{\prime}, 4^{\prime}, 6^{\prime}$-Tetra-O-benzoyl- $\beta$-D-glucopyranosyl)-5-(pyridin-2-yl) -1,3,4-oxadiazole (L-4)

Prepared from tetrazole [58,59] $2(5.00 \mathrm{~g}, 7.71 \mathrm{mmol})$ and 2-picolinic acid $(1.90 \mathrm{~g}$, $14.43 \mathrm{mmol}$ ) according to general procedure II. Reaction time: $5 \mathrm{~h}$. Purification by column chromatography (1:1 EtOAc-hexane) and crystallization from EtOH gave $1.96 \mathrm{~g}$ white solid $(35 \%) . R_{\mathrm{f}}=0.28$ (1:1 EtOAc-hexane). $[\alpha]_{\mathrm{D}}=-92\left(\mathrm{c} 0.20, \mathrm{CHCl}_{3}\right) .{ }^{1} \mathrm{H}-\mathrm{NMR}(400 \mathrm{MHz}$, $\left.\mathrm{CDCl}_{3}\right) \delta$ (ppm): $8.81(1 \mathrm{H}, \mathrm{d}, J=4.8 \mathrm{~Hz}, \mathrm{Py}-\mathrm{H}-6), 8.21(1 \mathrm{H}, \mathrm{d}, J=7.8 \mathrm{~Hz}, \mathrm{Py}-\mathrm{H}-3), 8.03-7.81$, 7.56-7.27 (22H, m, Ar, Py-H-4, Py-H-5), $6.10\left(1 \mathrm{H}, \mathrm{pt}, J=9.4,9.4 \mathrm{~Hz}, \mathrm{H}-3^{\prime}\right), 6.05(1 \mathrm{H}, \mathrm{pt}$, $\left.J=9.4,9.4 \mathrm{~Hz}, \mathrm{H}-2^{\prime}\right), 5.86\left(1 \mathrm{H}, \mathrm{pt}, J=9.4,9.4 \mathrm{~Hz}, \mathrm{H}-4^{\prime}\right), 5.28\left(1 \mathrm{H}, \mathrm{d}, J=9.4 \mathrm{~Hz}, \mathrm{H}-1^{\prime}\right), 4.67$ $\left(1 \mathrm{H}, \mathrm{dd}, J=12.4,2.3 \mathrm{~Hz}, \mathrm{H}-6^{\prime} \mathrm{a}\right), 4.54\left(1 \mathrm{H}, \mathrm{dd}, J=12.4,5.5 \mathrm{~Hz}, \mathrm{H}-6^{\prime} \mathrm{b}\right), 4.37(1 \mathrm{H}, \mathrm{ddd}, J=9.4$, 5.5, $\left.2.3 \mathrm{~Hz}, \mathrm{H}-5^{\prime}\right) ;{ }^{13} \mathrm{C}-\mathrm{NMR}\left(90 \mathrm{MHz}, \mathrm{CDCl}_{3}\right) \delta(\mathrm{ppm}): 166.2,165.8,165.2,165.1,164.9,162.2$ $(4 \times \mathrm{C}=\mathrm{O}$, OD-C-2, OD-C-5), 150.5 (Py-C-6), 143.2 (Py-C-2), 137.3 (Рy-C-4), 133.7, 133.6, 133.5, 133.2, 130.0-128.4 (Ar), 126.2 (Py-C-5), 123.5 (Py-C-3), 77.3 (C-5'), 73.8 (C-3'), 72.1 $\left(\mathrm{C}-1^{\prime}\right), 70.6\left(\mathrm{C}-2^{\prime}\right), 69.2\left(\mathrm{C}-4^{\prime}\right), 63.3\left(\mathrm{C}-6^{\prime}\right)$. ESI-HRMS positive mode $(\mathrm{m} / z)$ : calculated for $\mathrm{C}_{41} \mathrm{H}_{31} \mathrm{~N}_{3} \mathrm{NaO}_{10}{ }^{+}[\mathrm{M}+\mathrm{Na}]^{+}$748.1902. Found: 748.1907.

5.1.13. 2-( $\left(2^{\prime}, 3^{\prime}, 4^{\prime}, 6^{\prime}\right.$-Tetra-O-acetyl- $\beta$-D-glucopyranosyl)-5-(pyridin-2-yl)-1,3,4-oxadiazole (L-5)

To a solution of the 2-( $\beta$-D-glucopyranosyl)-5-(pyridin-2-yl)-1,3,4-oxadiazole (L-10, $20 \mathrm{mg}, 0.065 \mathrm{mmol})$ in dry pyridine $(0.5 \mathrm{~mL})$, acetic anhydride $(0.06 \mathrm{~mL}, 0.635 \mathrm{mmol})$ was added, and the mixture was stirred at $60{ }^{\circ} \mathrm{C}$. After $1 \mathrm{~h}$, the TLC (1:1 EtOAc-hexane) showed total consumption of L-10. The solvent was removed under reduced pressure, and the residue was purified by column chromatography (1:1 EtOAc-hexane). White amorphous solid, yield: $28 \mathrm{mg}(90 \%) . \mathrm{R}_{\mathrm{f}}=0.21\left(1: 1\right.$ EtOAc-hexane); $[\alpha]_{\mathrm{D}}=-61$ (c 0.19 , $\left.\mathrm{CHCl}_{3}\right) .{ }^{1} \mathrm{H}-\mathrm{NMR}\left(400 \mathrm{MHz}, \mathrm{CDCl}_{3}\right) \delta(\mathrm{ppm}): 8.82(1 \mathrm{H}, \mathrm{d}, J=4.4 \mathrm{~Hz}, \mathrm{Py}-\mathrm{H}-6), 8.26(1 \mathrm{H}, \mathrm{d}$, $J=7.9 \mathrm{~Hz}, \mathrm{Py}-\mathrm{H}-3), 7.91(1 \mathrm{H}, \mathrm{dt}, J=7.9,1.1 \mathrm{~Hz}, \mathrm{Py}-\mathrm{H}-4), 7.49(1 \mathrm{H}, \mathrm{m}, \mathrm{Py}-\mathrm{H}-5), 5.56(1 \mathrm{H}$, pt, $\left.J=9.8,9.7 \mathrm{~Hz}, \mathrm{H}-2^{\prime}\right), 5.40\left(1 \mathrm{H}, \mathrm{pt}, J=9.4,9.3 \mathrm{~Hz}, \mathrm{H}-3^{\prime}\right), 5.24(1 \mathrm{H}, \mathrm{pt}, J=9.8,9.7 \mathrm{~Hz}$, $\left.\mathrm{H}-4^{\prime}\right), 4.92\left(1 \mathrm{H}, \mathrm{d}, J=10.1 \mathrm{~Hz}, \mathrm{H}^{\prime} \mathbf{1}^{\prime}\right), 4.30\left(1 \mathrm{H}, \mathrm{dd}, J=12.6,5.1 \mathrm{~Hz}, \mathrm{H}-6^{\prime} \mathrm{a}\right), 4.18(1 \mathrm{H}, \mathrm{dd}$, $\left.J=12.6,2.2 \mathrm{~Hz}, \mathrm{H}-6^{\prime} \mathrm{b}\right), 3.91\left(1 \mathrm{H}, \mathrm{ddd}, J=9.7,5.1,2.2 \mathrm{~Hz}, \mathrm{H}-5^{\prime}\right), 2.09,2.07,2.04,1.94(4 \times 3 \mathrm{H}$, $\left.4 \mathrm{~s}, 4 \times \mathrm{CH}_{3}\right) ;{ }^{13} \mathrm{C}-\mathrm{NMR}\left(100 \mathrm{MHz}, \mathrm{CDCl}_{3}\right) \delta(\mathrm{ppm}): 170.7,170.3,169.4,169.3(4 \times \mathrm{C}=\mathrm{O})$, 165.1, 162.1 (OD-C-2, OD-C-5), 150.6 (Py-C-6), 143.2 (Py-C-2), 137.4 (Py-C-4), 126.3 (Py-C-5), 123.6 (Py-C-3), $76.9\left(\mathrm{C}-5^{\prime}\right), 73.5\left(\mathrm{C}-3^{\prime}\right), 71.6\left(\mathrm{C}-1^{\prime}\right), 69.7\left(\mathrm{C}-2^{\prime}\right), 68.0\left(\mathrm{C}-4^{\prime}\right), 62.0\left(\mathrm{C}-6^{\prime}\right), 20.8$, $20.7(2), 20.5\left(4 \times \mathrm{CH}_{3}\right)$. ESI-HRMS positive mode $(\mathrm{m} / z)$ : calculated for $\mathrm{C}_{21} \mathrm{H}_{23} \mathrm{~N}_{3} \mathrm{NaO}_{10}{ }^{+}$ $[\mathrm{M}+\mathrm{Na}]^{+}$500.1276. Found: 500.1275.

5.1.14. 2-(2', $3^{\prime}, 4^{\prime}$-Tri-O-benzoyl- $\beta$-D-xylopyranosyl)-5-(pyridin-2-yl)-1,3,4-oxadiazole (L-6)

Prepared from tetrazole [60] 3 (3.00 g, $5.83 \mathrm{mmol})$ and 2-picolinic acid (1.42 g, $11.53 \mathrm{mmol})$ according to general procedure II. Reaction time: $5 \mathrm{~h}$. Purification by column chromatography (2:1 EtOAc-hexane) and crystallization from $\mathrm{EtOH}$ yielded $2.00 \mathrm{~g}$ white solid (58\%). $\mathrm{R}_{\mathrm{f}}=0.35\left(4: 1 \mathrm{EtOAc}-\right.$ hexane); $[\alpha]_{\mathrm{D}}=-123\left(\mathrm{c} 0.20, \mathrm{CHCl}_{3}\right) .{ }^{1} \mathrm{H}-\mathrm{NMR}\left(360 \mathrm{MHz}, \mathrm{CDCl}_{3}\right) \delta$ (ppm): 8.80 (1H, d, J = 4.8 Hz, Py-H-6), 8.21 (1H, d, 7.9 Hz, Py-H-3), 7.99-7.83, 7.57-7.30 $(17 \mathrm{H}, \mathrm{m}, \mathrm{Ar}, \mathrm{Py}-\mathrm{H}-4, \mathrm{Py}-\mathrm{H}-5), 6.05\left(1 \mathrm{H}, \mathrm{pt}, J=9.2,9.2 \mathrm{~Hz}, \mathrm{H}-3^{\prime}\right), 5.96(1 \mathrm{H}, \mathrm{pt}, J=9.2,9.2 \mathrm{~Hz}$, H-2') $5.57\left(1 \mathrm{H}, \mathrm{ddd}, J=10.1,9.2,5.3 \mathrm{~Hz}, \mathrm{H}-4^{\prime}\right), 5.15\left(1 \mathrm{H}, \mathrm{d}, J=9.2 \mathrm{~Hz}, \mathrm{H}-1^{\prime}\right), 4.62(1 \mathrm{H}, \mathrm{dd}$, $\left.J=11.4,5.3 \mathrm{~Hz} \mathrm{~Hz}, \mathrm{H}-5^{\prime} \mathrm{eq}\right), 3.80\left(1 \mathrm{H}, \mathrm{pt}, J=11.4,10.1 \mathrm{~Hz}, \mathrm{H}-5^{\prime} \mathrm{ax}\right) ;{ }^{13} \mathrm{C}-\mathrm{NMR}(90 \mathrm{MHz}$, $\left.\mathrm{CDCl}_{3}\right) \delta$ (ppm): 165.8, 165.6, 165.1 (2), 162.5 (3 × C=O, OD-C-2, OD-C-5), 150.6 (Py-C-6), 143.3 (Py-C-2), 137.3 (Py-C-4), 133.7, 133.6, 133.5, 130.0-128.5 (Ar), 126.2 (Py-C-5), 123.5 (Py-C-3), $72.9\left(\mathrm{C}-3^{\prime}\right), 72.5\left(\mathrm{C}-1^{\prime}\right), 70.4\left(\mathrm{C}-2^{\prime}\right), 69.6\left(\mathrm{C}-4^{\prime}\right), 67.5\left(\mathrm{C}-5^{\prime}\right)$. ESI-HRMS positive mode $(m / z)$ : calculated for $\mathrm{C}_{33} \mathrm{H}_{25} \mathrm{~N}_{3} \mathrm{NaO}_{8}{ }^{+}[\mathrm{M}+\mathrm{Na}]^{+}$614.1534. Found: 614.1535. 
5.1.15. 2-( $\left(2^{\prime}, 3^{\prime}, 4^{\prime}, 6^{\prime}\right.$-Tetra-O-acetyl- $\beta$-D-galactopyranosyl)-5-(pyridin-2-yl) -1,3,4-oxadiazole (L-7)

Prepared from tetrazole [61] $4(0.50 \mathrm{~g}, 1.25 \mathrm{mmol})$ and 2-picolinic acid $(0.31 \mathrm{~g}, 2.50 \mathrm{mmol})$ according to general procedure II. Reaction time: $2 \mathrm{~h}$. Purification by column chromatography (1:1 EtOAc-hexane) and crystallization from $\mathrm{EtOH}$ yielded $0.30 \mathrm{~g}$ white solid (50\%). $\mathrm{R}_{\mathrm{f}}=0.17(1: 1 \mathrm{EtOAc}-$ hexane $) ;[\alpha]_{\mathrm{D}}=-41\left(\mathrm{c} 0.21, \mathrm{CHCl}_{3}\right) .{ }^{1} \mathrm{H}-\mathrm{NMR}\left(360 \mathrm{MHz}, \mathrm{CDCl}_{3}\right) \delta$ (ppm): 8.82 (1H, ddd, J = 4.8, 1.8, 0.9 Hz, Py-H-6), 8.27 (1H, dd, J = 7.9, 0.9 Hz, Py-H-3), 7.91 $(1 \mathrm{H}, \mathrm{dt}, J=7.9,1.8 \mathrm{~Hz}, \mathrm{Py}-\mathrm{H}-4), 7.50(1 \mathrm{H}, \mathrm{ddd}, J=7.7,4.8,1.1 \mathrm{~Hz}, \mathrm{Py}-\mathrm{H}-5), 5.67(1 \mathrm{H}, \mathrm{pt}$, $\left.J=10.1,10.0 \mathrm{~Hz}, \mathrm{H}-2^{\prime}\right), 5.56\left(1 \mathrm{H}, \mathrm{d}, J=3.4 \mathrm{~Hz}, \mathrm{H}-4^{\prime}\right), 5.24\left(1 \mathrm{H}, \mathrm{dd}, J=10.1,3.4 \mathrm{~Hz}, \mathrm{H}-3^{\prime}\right), 4.89$ $\left(1 \mathrm{H}, \mathrm{d}, J=10.0 \mathrm{~Hz}, \mathrm{H}-\mathrm{1}^{\prime}\right), 4.23-4.11\left(3 \mathrm{H}, \mathrm{m}, \mathrm{H}-5^{\prime}, \mathrm{H}-6^{\prime} \mathrm{a}, \mathrm{H}-6^{\prime} \mathrm{b}\right), 2.23,2.06,2.02,1.96(4 \times 3 \mathrm{H}$, $\left.4 \mathrm{~s}, 4 \times \mathrm{CH}_{3}\right) ;{ }^{13} \mathrm{C}-\mathrm{NMR}\left(90 \mathrm{MHz}, \mathrm{CDCl}_{3}\right) \delta(\mathrm{ppm}): 170.4,170.3,170.0,169.4,165.0,162.3$ $(4 \times \mathrm{C}=\mathrm{O}$, OD-C-2, OD-C-5), 150.5 (Py-C-6), 143.2 (Py-C-2), 137.3 (Py-C-4), 126.2 (Py-C-5), 123.6 (Py-C-3), $75.6\left(\mathrm{C}-5^{\prime}\right), 72.2\left(\mathrm{C}-1^{\prime}\right), 71.4\left(\mathrm{C}-3^{\prime}\right), 67.3\left(\mathrm{C}-4^{\prime}\right), 66.9\left(\mathrm{C}-2^{\prime}\right), 61.6\left(\mathrm{C}-6^{\prime}\right), 20.8$, 20.7, 20.6, $20.5\left(4 \times \mathrm{CH}_{3}\right)$. ESI-HRMS positive mode $(\mathrm{m} / z)$ : calculated for $\mathrm{C}_{21} \mathrm{H}_{24} \mathrm{~N}_{3} \mathrm{O}_{10}{ }^{+}$ $[\mathrm{M}+\mathrm{H}]^{+} 478.1456 ; \mathrm{C}_{21} \mathrm{H}_{23} \mathrm{~N}_{3} \mathrm{NaO}_{10}{ }^{+}[\mathrm{M}+\mathrm{Na}]^{+} 500.1276 ; \mathrm{C}_{42} \mathrm{H}_{46} \mathrm{~N}_{6} \mathrm{NaO}_{20}{ }^{+}[2 \mathrm{M}+\mathrm{Na}]^{+}$ 977.2659. Found: $[\mathrm{M}+\mathrm{H}]^{+}$478.1454; $[\mathrm{M}+\mathrm{Na}]^{+}$500.1274; $[2 \mathrm{M}+\mathrm{Na}]^{+}$977.2653.

5.1.16. 2-( $\left(2^{\prime}, 3^{\prime}, 4^{\prime}, 6^{\prime}\right.$-Tetra-O-benzoyl- $\beta$-D-galactopyranosyl) -5-(pyridin-2-yl)-1,3,4-oxadiazole (L-8)

The 2-( $\beta$-D-galactopyranosyl)-5-(pyridin-2-yl)-1,3,4-oxadiazole (L-10, $20.0 \mathrm{mg}, 0.065 \mathrm{mmol}$ ) was suspended in dry pyridine $(0.5 \mathrm{~mL})$, and benzoyl chloride $(36 \mu \mathrm{L}, 0.310 \mathrm{mmol})$ was added. The reaction mixture was stirred at $60^{\circ} \mathrm{C}$ until the TLC (3:2 EtOAc-hexane) showed complete disappearance of the starting material $(1 \mathrm{~h})$. The solvent was removed under diminished pressure. The residue was dissolved in $\mathrm{CH}_{2} \mathrm{Cl}_{2}(20 \mathrm{~mL})$ and extracted with sat. aq. $\mathrm{NaHCO}_{3}(10 \mathrm{~mL})$ and then with water $(10 \mathrm{~mL})$. The organic phase was dried over $\mathrm{MgSO}_{4}$, filtered, and evaporated. Purification by column chromatography (3:2 EtOAchexane) yielded $38 \mathrm{mg}$ of white amorphous solid $(81 \%) . \mathrm{R}_{\mathrm{f}}=0.27$ (3:2 EtOAc-hexane); $[\alpha]_{\mathrm{D}}=+9\left(\mathrm{c} 0.20, \mathrm{CHCl}_{3}\right) .{ }^{1} \mathrm{H}-\mathrm{NMR}\left(400 \mathrm{MHz}, \mathrm{CDCl}_{3}\right) \delta(\mathrm{ppm}): 8.81(1 \mathrm{H}, \mathrm{d}, J=4.8 \mathrm{~Hz}$, Py-H-6), $8.21(1 \mathrm{H}, \mathrm{d}, J=7.9$ Hz, Py-H-3), 8.17-7.23 (22H, m, Ar, Py-H-4, Py-H-5), $6.32(1 \mathrm{H}$, pt, $\left.J=10.1,10.0 \mathrm{~Hz}, \mathrm{H}-2^{\prime}\right), 6.16\left(1 \mathrm{H}, \mathrm{d}, J=3.3 \mathrm{~Hz}, \mathrm{H}-4^{\prime}\right), 5.84(1 \mathrm{H}, \mathrm{dd}, J=10.1,3.3 \mathrm{~Hz}$, H-3') $5.30\left(1 \mathrm{H}, \mathrm{d}, J=10.0 \mathrm{~Hz}, \mathrm{H}-1^{\prime}\right), 4.68\left(1 \mathrm{H}, \mathrm{dd}, J=11.1,6.4 \mathrm{~Hz}, \mathrm{H}-6^{\prime} \mathrm{a}\right), 4.58(1 \mathrm{H}, \mathrm{pt}$, $\left.J=6.4,5.9 \mathrm{~Hz}, \mathrm{H}-5^{\prime}\right), 4.49\left(1 \mathrm{H}, \mathrm{dd}, J=11.1,5.9 \mathrm{~Hz}, \mathrm{H}-6^{\prime} \mathrm{b}\right) ;{ }^{13} \mathrm{C}-\mathrm{NMR}\left(100 \mathrm{MHz}, \mathrm{CDCl}_{3}\right) \delta$ (ppm): 166.2, 165.7, 165.6, 165.1, 165.0, $162.4(4 \times \mathrm{C}=\mathrm{O}$, OD-C-2, OD-C-5), 150.5 (Py-C-6), 143.3 (Py-C-2), 137.3 (Py-C-4), 133.8, 133.6, 133.5, 133.4, 130.2-130.0, 129.9-128.5 (Ar), 126.2 (Py-C-5), 123.6 (Py-C-3), 76.1 (C-5'), 72.5, $72.3\left(\mathrm{C}-1^{\prime}, \mathrm{C}-3^{\prime}\right), 68.4\left(\mathrm{C}-4^{\prime}\right), 67.9\left(\mathrm{C}-2^{\prime}\right), 62.3\left(\mathrm{C}-6^{\prime}\right)$. ESI-HRMS positive mode $(\mathrm{m} / \mathrm{z})$ : calculated for $\mathrm{C}_{41} \mathrm{H}_{31} \mathrm{~N}_{3} \mathrm{NaO}_{10}{ }^{+}[\mathrm{M}+\mathrm{Na}]^{+}$748.1902. Found: 748.1901.

\subsubsection{2-(L-Arabino-1' $2^{\prime}, 3^{\prime}, 4^{\prime}$-tetraacetoxybutyl)-5-(pyridin-2-yl)-1,3,4-oxadiazole (L-9)}

Prepared from tetrazole [33] 5 (3.50 g, $9.77 \mathrm{mmol})$ and 2-picolinic acid (2.41 g, $19.58 \mathrm{mmol})$ according to general procedure II. Reaction time: $5 \mathrm{~h}$. Purification by column chromatography (1:1 $\rightarrow$ 2:1 $\rightarrow$ 3:1 EtOAc-hexane) yielded $0.57 \mathrm{~g}$ of white amorphous solid (13\%). $\mathrm{R}_{\mathrm{f}}=0.27\left(4: 1\right.$ EtOAc-hexane); $[\alpha]_{\mathrm{D}}=+6\left(\mathrm{c} 0.20, \mathrm{CHCl}_{3}\right) .{ }^{1} \mathrm{H}-\mathrm{NMR}\left(400 \mathrm{MHz}, \mathrm{CDCl}_{3}\right) \delta$ (ppm): 8.79 (1H, d, J = 4.4 Hz, Py-H-6), $8.26(1 \mathrm{H}, \mathrm{d}, J=7.9 \mathrm{~Hz}, \mathrm{Py}-\mathrm{H}-3), 7.90(1 \mathrm{H}, \mathrm{dt}, J=7.8$, 1.4 Hz, Py-H-4), 7.49 (1H, m, Py-H-5), $6.35\left(1 \mathrm{H}, \mathrm{d}, J=2.2 \mathrm{~Hz}, \mathrm{H}-1^{\prime}\right), 5.69(1 \mathrm{H}, \mathrm{dd}, J=9.4$, $\left.2.2 \mathrm{~Hz}, \mathrm{H}-2^{\prime}\right), 5.36\left(1 \mathrm{H}, \mathrm{ddd}, J=9.4,3.9,2.3 \mathrm{~Hz}, \mathrm{H}-3^{\prime}\right), 4.35\left(1 \mathrm{H}, \mathrm{dd}, J=12.6,2.3 \mathrm{~Hz}, \mathrm{H}-4^{\prime} \mathrm{a}\right)$, $4.23\left(1 \mathrm{H}, \mathrm{dd}, J=12.6,3.9 \mathrm{~Hz}, \mathrm{H}-4^{\prime} \mathrm{b}\right), 2.22,2.11,2.10,2.06\left(4 \times 3 \mathrm{H}, 4 \mathrm{~s}, \mathrm{CH}_{3}\right) ;{ }^{13} \mathrm{C}-\mathrm{NMR}$ $\left(100 \mathrm{MHz}, \mathrm{CDCl}_{3}\right) \delta$ (ppm): 170.6, 169.7, $169.6(2)(4 \times \mathrm{C}=\mathrm{O}), 164.5,162.6$ (OD-C-2, OD-C-5), 150.4 (Py-C-6), 143.1 (Py-C-2), 137.4 (Py-C-4), 126.3 (Py-C-5), 123.5 (Py-C-3), 68.7 (C-2'), 67.8 $\left(\mathrm{C}-3^{\prime}\right), 64.4\left(\mathrm{C}-1^{\prime}\right), 61.5\left(\mathrm{C}-4^{\prime}\right), 20.8,20.7,20.5(2)\left(4 \times \mathrm{CH}_{3}\right)$. ESI-HRMS positive mode $(\mathrm{m} / \mathrm{z})$ : calculated for $\mathrm{C}_{19} \mathrm{H}_{22} \mathrm{~N}_{3} \mathrm{O}_{9}{ }^{+}[\mathrm{M}+\mathrm{H}]^{+} 436.1351 ; \mathrm{C}_{19} \mathrm{H}_{21} \mathrm{~N}_{3} \mathrm{NaO}_{9}{ }^{+}[\mathrm{M}+\mathrm{Na}]^{+} 458.1170$. Found: $[\mathrm{M}+\mathrm{H}]^{+}$436.1349; [M+ Na] $]^{+} 458.1170$. 
5.1.18. 2-( $\beta$-D-Glucopyranosyl)-5-(pyridin-2-yl)-1,3,4-oxadiazole (L-10)

Prepared from compound L-4 $(0.60 \mathrm{~g}, 0.83 \mathrm{mmol})$ according to general procedure III. Purified by column chromatography $\left(9: 1 \mathrm{CHCl}_{3}-\mathrm{MeOH}\right)$ to give $0.22 \mathrm{~g}$ white amorphous solid $(87 \%) . \mathrm{R}_{\mathrm{f}}=0.29\left(8: 2 \mathrm{CHCl}_{3}-\mathrm{MeOH}\right) ;[\alpha]_{\mathrm{D}}=+17(\mathrm{c} 0.20, \mathrm{MeOH}) .{ }^{1} \mathrm{H}-\mathrm{NMR}(360 \mathrm{MHz}$, $\left.\mathrm{CD}_{3} \mathrm{OD}\right) \delta(\mathrm{ppm}): 8.75(1 \mathrm{H}, \mathrm{ddd}, J=4.9,1.7,0.9 \mathrm{~Hz}, \mathrm{Py}-\mathrm{H}-6), 8.25(1 \mathrm{H}, \mathrm{dd}, J=7.9,1.1 \mathrm{~Hz}$, Py-H-3), $8.07(1 \mathrm{H}, \mathrm{dt}, J=7.9,1.7$ Hz, Py-H-4), $7.64(1 \mathrm{H}, \mathrm{ddd}, J=7.9,4.9,1.1 \mathrm{~Hz}, \mathrm{Py}-\mathrm{H}-5), 4.68$ $\left(1 \mathrm{H}, \mathrm{d}, J=9.9 \mathrm{~Hz}, \mathrm{H}-1^{\prime}\right), 3.90\left(1 \mathrm{H}, \mathrm{dd}, J=12.2,1.9 \mathrm{~Hz}, \mathrm{H}-6^{\prime} \mathrm{a}\right), 3.84(1 \mathrm{H}, \mathrm{dd}, J=9.9,8.7 \mathrm{~Hz}$, $\left.\mathrm{H}-2^{\prime}\right), 3.70\left(1 \mathrm{H}, J=12.2,5.4 \mathrm{~Hz}, \mathrm{H}-6^{\prime} \mathrm{b}\right), 3.54\left(1 \mathrm{H}, \mathrm{pt}, J=8.9,8.6 \mathrm{~Hz}, \mathrm{H}-3^{\prime}\right), 3.54-3.50(1 \mathrm{H}$, m, H-5 $\left.{ }^{\prime}\right), 3.46\left(1 \mathrm{H}, \mathrm{pt}, J=9.3,8.8 \mathrm{~Hz}, \mathrm{H}-4^{\prime}\right) ;{ }^{13} \mathrm{C}-\mathrm{NMR}\left(90 \mathrm{MHz}, \mathrm{CD}_{3} \mathrm{OD}\right) \delta(\mathrm{ppm}): 166.4$, 165.7 (OD-C-2, OD-C-5), 151.4 (Py-C-6), 144.0 (Py-C-2), 139.3 (Py-C-4), 127.9 (Py-C-5), 124.5 (Py-C-3), $82.9\left(\mathrm{C}-5^{\prime}\right), 79.1\left(\mathrm{C}-3^{\prime}\right), 74.7\left(\mathrm{C}-1^{\prime}\right), 73.4\left(\mathrm{C}-2^{\prime}\right), 71.3\left(\mathrm{C}-4^{\prime}\right), 62.8\left(\mathrm{C}-6^{\prime}\right)$. ESI-HRMS positive mode $(m / z)$ : calculated for $\mathrm{C}_{13} \mathrm{H}_{15} \mathrm{~N}_{3} \mathrm{NaO}_{6}{ }^{+}[\mathrm{M}+\mathrm{Na}]^{+}$332.0853. Found: 332.0844 .

\subsubsection{2-( $\beta$-D-Xylopyranosyl)-5-(pyridin-2-yl)-1,3,4-oxadiazole (L-11)}

Prepared from compound L-6 (500 $\mathrm{mg}, 0.85 \mathrm{mmol})$ according to general procedure III. Purified by column chromatography $\left(9: 1 \mathrm{CHCl}_{3}-\mathrm{MeOH}\right)$ to give $82 \mathrm{mg}$ white amorphous solid (35\%). $\mathrm{R}_{\mathrm{f}}=0.27\left(9: 1 \mathrm{CHCl}_{3}-\mathrm{MeOH}\right) ;[\alpha]_{\mathrm{D}}=-44(\mathrm{c} 0.20, \mathrm{MeOH}) .{ }^{1} \mathrm{H}-\mathrm{NMR}(360 \mathrm{MHz}$, $\left.\mathrm{CD}_{3} \mathrm{OD}\right) \delta$ (ppm): $8.74(1 \mathrm{H}, \mathrm{ddd}, J=4.9,1.6,0.9 \mathrm{~Hz}, \mathrm{Py}-\mathrm{H}-6), 8.24(1 \mathrm{H}, \mathrm{ddd}, J=7.9,1.1$, $0.9 \mathrm{~Hz}, \mathrm{Py}-\mathrm{H}-3), 8.06(1 \mathrm{H}, \mathrm{dt}, J=7.9,1.6 \mathrm{~Hz}, \mathrm{Py}-\mathrm{H}-4), 7.63(1 \mathrm{H}, \mathrm{ddd}, J=7.7,4.9,1.1 \mathrm{~Hz}$, Py-H-5), $4.59\left(1 \mathrm{H}, \mathrm{d}, J=9.8 \mathrm{~Hz}, \mathrm{H}-1^{\prime}\right), 4.03\left(1 \mathrm{H}, \mathrm{dd}, J=11.1,5.4 \mathrm{~Hz}, \mathrm{H}-5^{\prime}\right.$ eq $), 3.84(1 \mathrm{H}$, pt, $\left.J=9.8,9.1 \mathrm{~Hz}, \mathrm{H}-2^{\prime}\right), 3.66\left(1 \mathrm{H}, \mathrm{td}, J=10.1,9.1,5.4 \mathrm{~Hz}, \mathrm{H}-4^{\prime}\right), 3.47(1 \mathrm{H}, \mathrm{pt}, J=9.1$, $\left.9.1 \mathrm{~Hz}, \mathrm{H}-3^{\prime}\right), 3.41\left(1 \mathrm{H}, \mathrm{pt}, J=11.1,10.1 \mathrm{~Hz}, \mathrm{H}-5^{\prime} \mathrm{ax}\right){ }^{13}{ }^{13} \mathrm{C}-\mathrm{NMR}\left(90 \mathrm{MHz}, \mathrm{CD}_{3} \mathrm{OD}\right) \delta(\mathrm{ppm})$ : 166.4, 165.7 (OD-C-2, OD-C-5), 151.4 (Py-C-6), 144.0 (Py-C-2), 139.3 (Py-C-4), 127.9 (Py-C-5), 124.5 (Py-C-3), $79.2\left(\mathrm{C}-3^{\prime}\right), 75.4\left(\mathrm{C}-1^{\prime}\right), 73.4\left(\mathrm{C}-2^{\prime}\right), 71.7\left(\mathrm{C}-5^{\prime}\right), 71.0$ (C-4'). ESI-HRMS positive mode $(m / z)$ : calculated for $\mathrm{C}_{12} \mathrm{H}_{13} \mathrm{~N}_{3} \mathrm{NaO}_{5}{ }^{+}[\mathrm{M}+\mathrm{Na}]^{+} 302.0747 ; \mathrm{C}_{24} \mathrm{H}_{26} \mathrm{~N}_{6} \mathrm{NaO}_{10}{ }^{+}[2 \mathrm{M}+$ $\mathrm{Na}]^{+}$581.1603. Found: $[\mathrm{M}+\mathrm{Na}]^{+}$302.0747; $[2 \mathrm{M}+\mathrm{Na}]^{+} 581.1604$. $^{2}$

\subsubsection{2-( $\beta$-D-Galactopyranosyl)-5-(pyridin-2-yl)-1,3,4-oxadiazole (L-12)}

Prepared from compound L-7 (350 $\mathrm{mg}, 0.73 \mathrm{mmol})$ according to general procedure III. Purified by column chromatography $\left(7: 2 \mathrm{CHCl}_{3}-\mathrm{MeOH}\right)$ to give $177 \mathrm{mg}$ white amorphous solid $(78 \%) . \mathrm{R}_{\mathrm{f}}=0.33\left(7: 2 \mathrm{CHCl}_{3}-\mathrm{MeOH}\right) ;[\alpha]_{\mathrm{D}}=+25(\mathrm{c} 0.21, \mathrm{MeOH}) .{ }^{1} \mathrm{H}-\mathrm{NMR}(400 \mathrm{MHz}$, $\left.\mathrm{CD}_{3} \mathrm{OD}\right) \delta(\mathrm{ppm}): 8.77(1 \mathrm{H}, \mathrm{d}, J=4.8 \mathrm{~Hz}, \mathrm{Py}-\mathrm{H}-6), 8.27(1 \mathrm{H}, \mathrm{d}, J=7.9 \mathrm{~Hz}, \mathrm{Py}-\mathrm{H}-3), 8.08$ $(1 \mathrm{H}, \mathrm{dt}, J=7.9,1.5 \mathrm{~Hz}, \mathrm{Py}-\mathrm{H}-4), 7.65(1 \mathrm{H}, \mathrm{m}, \mathrm{Py}-\mathrm{H}-5), 4.63\left(1 \mathrm{H}, \mathrm{d}, J=9.8 \mathrm{~Hz}, \mathrm{H}-\mathrm{-}^{\prime}\right), 4.22$ $\left(1 \mathrm{H}, \mathrm{pt}, J=9.8,9.6 \mathrm{~Hz}, \mathrm{H}-2^{\prime}\right), 4.01\left(1 \mathrm{H}, \mathrm{d}, J=3.2 \mathrm{~Hz}, \mathrm{H}-4^{\prime}\right), 3.84-3.73\left(3 \mathrm{H}, \mathrm{m}, \mathrm{H}-5^{\prime}, \mathrm{H}-6^{\prime} \mathrm{a}\right.$, H-6'b), $3.67\left(1 \mathrm{H}, \mathrm{dd}, J=9.6,3.2 \mathrm{~Hz}, \mathrm{H}-3^{\prime}\right) ;{ }^{13} \mathrm{C}-\mathrm{NMR}\left(90 \mathrm{MHz}, \mathrm{CD}_{3} \mathrm{OD}\right) \delta(\mathrm{ppm}): 166.5$, 165.7 (OD-C-2, OD-C-5), 151.4 (Py-C-6), 144.1 (Py-C-2), 139.3 (Py-C-4), 127.9 (Py-C-5), 124.5 (Py-C-3), $81.7\left(\mathrm{C}-5^{\prime}\right), 75.8\left(\mathrm{C}-3^{\prime}\right), 75.1\left(\mathrm{C}-1^{\prime}\right), 70.7\left(\mathrm{C}-4^{\prime}\right), 70.2\left(\mathrm{C}-2^{\prime}\right), 62.8\left(\mathrm{C}-6^{\prime}\right)$. ESI-HRMS positive mode $(\mathrm{m} / \mathrm{z})$ : calculated for $\mathrm{C}_{13} \mathrm{H}_{16} \mathrm{~N}_{3} \mathrm{O}_{6}{ }^{+}[\mathrm{M}+\mathrm{H}]^{+} 310.1034 ; \mathrm{C}_{13} \mathrm{H}_{15} \mathrm{~N}_{3} \mathrm{NaO}_{6}{ }^{+}$ $[\mathrm{M}+\mathrm{Na}]^{+}$332.0853; $\mathrm{C}_{26} \mathrm{H}_{30} \mathrm{~N}_{6} \mathrm{NaO}_{12}{ }^{+}[2 \mathrm{M}+\mathrm{Na}]^{+}$641.1814. Found: $[\mathrm{M}+\mathrm{H}]^{+} 310.1035 ;$ $[\mathrm{M}+\mathrm{Na}]^{+} 332.0852 ;[2 \mathrm{M}+\mathrm{Na}]^{+} 641.1815$.

\subsubsection{Complex Ru-1a}

Prepared from complex Ru-dimer (50 mg, $0.082 \mathrm{mmol}$ ), compound L-1a (86 mg, $0.181 \mathrm{mmol}, 2.2 \mathrm{eq}$.$) , and \mathrm{TlPF}_{6}(57 \mathrm{mg}, 0.163 \mathrm{mmol})$ according to general procedure IV. Purified by column chromatography $\left(9: 1 \mathrm{CHCl}_{3}-\mathrm{MeOH}\right)$ to give $143 \mathrm{mg}(98 \%)$ yellow powder. $\mathrm{R}_{\mathrm{f}}$ : 0.32 (9:1 $\left.\mathrm{CHCl}_{3}-\mathrm{MeOH}\right)$. Diastereomeric ratio: 1:1. ${ }^{1} \mathrm{H}-\mathrm{NMR}\left(400 \mathrm{MHz}, \mathrm{CDCl}_{3}\right)$ $\delta$ (ppm): 9.25, $9.22(2 \times 1 \mathrm{H}, 2 \mathrm{~d}, J=5.5 \mathrm{~Hz}$ in each, $2 \times \mathrm{Py}-\mathrm{H}-6), 8.92,8.79(2 \times 1 \mathrm{H}, 2 \mathrm{~s}$, $2 \times$ Tria-H-5), $7.96(2 \mathrm{H}, \mathrm{t}, J=7.6 \mathrm{~Hz}, 2 \times \mathrm{Py}-\mathrm{H}-4), 7.89(2 \mathrm{H}, \mathrm{d}, J=7.8 \mathrm{~Hz}, 2 \times$ Py-H-3), 7.57-7.52 (2H, m, $2 \times$ Py-H-5), 6.00, $5.99\left(2 \times 1 \mathrm{H}, 2 \mathrm{~d}, J=9.4 \mathrm{~Hz}\right.$ in each, $\left.2 \times \mathrm{H}-1^{\prime}\right), 5.95-5.83$, $5.73-5.67\left(10 \mathrm{H}, \mathrm{m}, 2 \times 4 \times p\right.$-cym- $\left.-\mathrm{CH}_{\mathrm{Ar}}, 2 \times \mathrm{H}-2^{\prime}\right), 5.47,5.46(2 \times 1 \mathrm{H}, 2 \mathrm{pt}, J=9.4,9.2 \mathrm{~Hz}$ in each, $\left.2 \times \mathrm{H}-3^{\prime}\right), 5.35,5.33\left(2 \times 1 \mathrm{H}, 2 \mathrm{pt}, J=9.7,9.7 \mathrm{~Hz}\right.$ in each, $\left.2 \times \mathrm{H}-4^{\prime}\right), 4.38,4.32(2 \times 1 \mathrm{H}$, $2 \mathrm{dd}, J=12.8,4.7 \mathrm{~Hz}$ in each, $\left.2 \times \mathrm{H}-6^{\prime} \mathrm{a}\right), 4.26-4.15\left(4 \mathrm{H}, \mathrm{m}, 2 \times \mathrm{H}-5^{\prime}, 2 \times \mathrm{H}-6^{\prime} \mathrm{b}\right), 2.79,2.74$ $\left(2 \times 1 \mathrm{H}, 2\right.$ hept, $J=6.9 \mathrm{~Hz}$ in each, $2 \times i$-Pr-CH) $, 2.22,2.20\left(2 \times 3 \mathrm{H}, 2 \mathrm{~s}, 2 \times \mathrm{C}_{6} \mathrm{H}_{4}-\mathrm{CH}_{3}\right)$, $2.10,2.09,2.05,1.95,1.93\left(24 \mathrm{H}\right.$, singlets, $\left.2 \times 4 \times \mathrm{COCH}_{3}\right), 1.17-1.12(12 \mathrm{H}, \mathrm{m}, 2 \times 2 \times$ 
$i$-Pr-CH $\left.{ }_{3}\right) ;{ }^{13} \mathrm{C}-\mathrm{NMR}\left(90 \mathrm{MHz}, \mathrm{CDCl}_{3}\right) \delta(\mathrm{ppm}): 170.8,170.7,170.0,169.9,169.6,169.5,169.4$, $169.2(2 \times 4 \times \mathrm{C}=\mathrm{O}), 155.5,155.4(2 \times$ Py-C-6) $), 147.6,147.5,147.1,146.7(2 \times$ Tria-C-4, 2 $\times$ Py-C-2), 140.3, $140.2(2 \times$ Py-C-4), 127.1, $126.9(2 \times$ Py-C-5), 125.4, 125.3 (2 $\times$ Tria-C-5), 122.9 (2) $\left(2 \times\right.$ Py-C-3), 106.3, 105.5, 103.1, $101.8\left(2 \times 2 \times\right.$ p-cym-C qAr $\left._{\text {. }}\right), 86.8,86.7\left(2 \times \mathrm{C}^{\prime} 1^{\prime}\right)$, 86.4, 85.4, 85.3, 85.0, 84.8, 83.9, 83.9, $83.1\left(2 \times 4 \times p\right.$-cym-CH $\left.\mathrm{CH}_{\mathrm{Ar}}\right), 75.5,75.3\left(2 \times \mathrm{C}-5^{\prime}\right), 73.1$, $73.0\left(2 \times \mathrm{C}^{-} 3^{\prime}\right), 70.2,69.8\left(2 \times \mathrm{C}-2^{\prime}\right), 67.6,67.5\left(2 \times \mathrm{C}-4^{\prime}\right), 61.6,61.5\left(2 \times \mathrm{C}-6^{\prime}\right), 31.1,31.0(2$ $\times i$-Pr-CH) $, 22.5,22.2,22.1,21.7\left(2 \times 2 \times i-\mathrm{Pr}-\mathrm{CH}_{3}\right), 20.8-20.3\left(2 \times 4 \times \mathrm{COCH}_{3}\right), 18.7$ (2) $\left(2 \times \mathrm{C}_{6} \mathrm{H}_{4}-\mathrm{CH}_{3}\right)$. ESI-HRMS positive mode $(\mathrm{m} / z)$ : calculated for $\mathrm{C}_{31} \mathrm{H}_{38} \mathrm{ClN}_{4} \mathrm{O}_{9} \mathrm{Ru}^{+}$ $\left[\mathrm{M}-\mathrm{PF}_{6}\right]^{+}$747.1371. Found: 747.1370.

\subsubsection{Complex Ru-1b}

Prepared from complex Ru-dimer (50 mg, $0.082 \mathrm{mmol}$ ), compound L-1b (95 mg, $0.180 \mathrm{mmol}, 2.2 \mathrm{eq}$.), and $\mathrm{TlPF}_{6}(57 \mathrm{mg}, 0.163 \mathrm{mmol})$ according to general procedure IV. Purified by column chromatography $\left(9: 1 \mathrm{CHCl}_{3}-\mathrm{MeOH}\right)$ to give $145 \mathrm{mg}(96 \%)$ yellow powder. $\mathrm{R}_{\mathrm{f}}$ : 0.55 (9:1 $\left.\mathrm{CHCl}_{3}-\mathrm{MeOH}\right)$. Diastereomeric ratio: 2:1. ${ }^{1} \mathrm{H}-\mathrm{NMR}\left(400 \mathrm{MHz}, \mathrm{CDCl}_{3}\right)$ $\delta$ (ppm): 9.24 (s, minor Tria-H-5), 9.03 (s, major Tria-H-5), 8.75 (d, $J=8.8 \mathrm{~Hz}$, major Qu-H-8), $8.68(\mathrm{~d}, J=8.7 \mathrm{~Hz}$, minor Qu-H-8), $8.39(\mathrm{~d}, J=8.6 \mathrm{~Hz}$, major Qu-H-4), $8.37(\mathrm{~d}, J=8.9 \mathrm{~Hz}$, minor Qu-H-4), 8.04-7.89, 7.75-7.70 (2 m, minor and major Qu-H-3, Qu-H-5-Qu-H-7), $6.11\left(\mathrm{~d}, J=9.4 \mathrm{~Hz}\right.$, minor $\left.\mathrm{H}-1^{\prime}\right), 6.08\left(\mathrm{~d}, J=9.2 \mathrm{~Hz}\right.$, major $\left.\mathrm{H}-1^{\prime}\right), 6.03(\mathrm{pt}, J=9.2,9.0 \mathrm{~Hz}$, major $\left.\mathrm{H}-2^{\prime}\right), 5.97\left(\mathrm{pt}, J=9.4,9.0 \mathrm{~Hz}\right.$, minor $\left.\mathrm{H}-2^{\prime}\right), 5.96,5.95(2 \mathrm{~d}, J=6.0 \mathrm{~Hz}$ in each, major $p$-cym- $\left.\mathrm{CH}_{\mathrm{Ar}}\right) 5.88,5.84\left(2 \mathrm{~d}, J=6.0 \mathrm{~Hz}\right.$ in each, minor $p$-cym- $\left.-\mathrm{CH}_{\mathrm{Ar}}\right) 5.83-5.80(\mathrm{~m}$, minor and major $p$-cym- $\left.\mathrm{CH}_{\mathrm{Ar}}\right), 5.78\left(\mathrm{~d}, J=6.0 \mathrm{~Hz}\right.$, minor $p$-cym- $\left.-\mathrm{CH}_{\mathrm{Ar}}\right), 5.67(\mathrm{~d}, J=5.9 \mathrm{~Hz}$, major $p$-cym- $\left.\mathrm{CH}_{\mathrm{Ar}}\right), 5.52(\mathrm{pt}, J=9.2,9.2 \mathrm{~Hz}$, major H-3'), $5.49(\mathrm{pt}, J=9.5,9.4 \mathrm{~Hz}$, minor H-3'), 5.39 $\left(\mathrm{pt}, J=10.2,9.7 \mathrm{~Hz}\right.$, minor $\left.\mathrm{H}^{\prime} 4^{\prime}\right), 5.34\left(\mathrm{pt}, J=10.0,9.7 \mathrm{~Hz}\right.$, major $\left.\mathrm{H}-4^{\prime}\right), 4.44(\mathrm{dd}, J=12.7$, $4.7 \mathrm{~Hz}$, minor H-6' a), 4.33 (dd, $J=12.7,5.1 \mathrm{~Hz}$, major $\left.\mathrm{H}-6^{\prime} \mathrm{a}\right), 4.32-4.17$ (m, minor and major $\mathrm{H}-5^{\prime}, \mathrm{H}^{\prime} 6^{\prime} \mathrm{b}$ ), 2.57 (hept, $J=6.9 \mathrm{~Hz}$, major $i-\mathrm{Pr}-\mathrm{CH}$ ), 2.53 (hept, $J=6.9 \mathrm{~Hz}$, minor $i-\mathrm{Pr}-\mathrm{CH}$ ), 2.15 (s, minor $\mathrm{C}_{6} \mathrm{H}_{4}-\mathrm{CH}_{3}$ ), 2.13, 2.09 (singlets, $\mathrm{COCH}_{3}$ ), 2.07 (s, major $\mathrm{C}_{6} \mathrm{H}_{4}-\mathrm{CH}_{3}$ ), 2.06, 2.02, 1.96 (singlets, $\left.\left.\mathrm{COCH}_{3}\right), 1.07,1.04(2 \mathrm{~d}, J=6.9 \mathrm{~Hz} \text { in each, } 2 \times \text { major } i \text {-Pr-CH})_{3}\right), 1.02,1.00(2 \mathrm{~d}$, $J=6.9 \mathrm{~Hz}$ in each, $2 \times$ minor $i$-Pr-CH 3$) ;{ }^{13} \mathrm{C}-\mathrm{NMR}\left(90 \mathrm{MHz}, \mathrm{CDCl}_{3}\right) \delta(\mathrm{ppm}): 170.9,170.0$, 169.6, 169.4 (minor $4 \times \mathrm{C}=\mathrm{O}$ ), 170.8, 170.1, 169.8, 169.7 (major $4 \times \mathrm{C}=\mathrm{O}$ ), 149.6, 148.4, 147.5 (major Tria-C-4, Qu-C-2, Qu-C-8a), 149.2, 148.4, 148.9 (minor Tria-C-4, Qu-C-2, Qu-C-8a), 141.3 (minor Qu-C-4), 141.0 (major Qu-C-4), 133.1, 129.6, 129.2, 129.1, 129.1 (minor Qu-C-4a, Qu-C-5-Qu-C-8), 132.7, 129.5, 129.1, 129.1, 129.0 (major Qu-C-4a, Qu-C-5-Qu-C-8), 127.6 (major Tria-C-5), 127.5 (minor Tria-C-5), 119.1 (major Qu-C-3), 118.8 (minor Qu-C-3), 106.3, 102.1 (minor $p$-cym- $\mathrm{C}_{\mathrm{qAr}}$ ), 105.4, 102.7 (major $p$-cym- $\mathrm{C}_{\mathrm{qAr}}$ ), 88.1, 86.7, 86.5, 86.4, 85.7, 85.1, 84.6, 84.5, 84.3, 84.0 (minor and major $p$-cym- $\mathrm{CH}_{\mathrm{Ar}}$, minor and major $\mathrm{C}-1^{\prime}$ ), 75.6 (minor C-5'), 75.2 (major C-5'), 73.2 (minor C-3'), 73.0 (major C-3'), 70.2 (major C-2'), 69.8 (minor C-2'), 67.5 (major C-4'), 67.7 (minor C-4'), 61.6 (major C-6'), 61.5 (minor C-6'), 31.3 (minor $i$-Pr-CH), 31.1 (major $i$-Pr-CH), 22.7, 21.6 (major $\left.i-\mathrm{Pr}_{-} \mathrm{CH}_{3}\right), 22.4,21.8$ (minor $\left.i-\mathrm{Pr}-\mathrm{CH}_{3}\right), 20.8$, 20.7, 20.7, 20.6, $20.4\left(2 \times 4 \times \mathrm{COCH}_{3}\right), 18.7\left(\right.$ minor $\left.\mathrm{C}_{6} \mathrm{H}_{4}-\mathrm{CH}_{3}\right), 18.5$ (major $\left.\mathrm{C}_{6} \mathrm{H}_{4}-\mathrm{CH}_{3}\right)$. ESI-HRMS positive mode $(m / z)$ : calculated for $\mathrm{C}_{35} \mathrm{H}_{40} \mathrm{ClN}_{4} \mathrm{O}_{9} \mathrm{Ru}^{+}\left[\mathrm{M}-\mathrm{PF}_{6}\right]^{+}$797.1528. Found: 797.1531.

\subsubsection{Complex Ru-2a}

Prepared from complex Ru-dimer (10.0 mg, $0.0163 \mathrm{mmol})$, compound L-2a (24.9 mg, $0.0344 \mathrm{mmol}, 2.1$ eq.), and $\mathrm{TlPF}_{6}(11.4 \mathrm{mg}, 0.0326 \mathrm{mmol}, 2$ eq.) according to general procedure IV. Purified by column chromatography $\left(95: 5 \mathrm{CHCl}_{3}-\mathrm{MeOH}\right)$ to give $34.6 \mathrm{mg}$ (93\%) orange powder. $\mathrm{R}_{\mathrm{f}}$ : $0.46\left(95: 5 \mathrm{CHCl}_{3}-\mathrm{MeOH}\right)$. Diastereomeric ratio: 1:1. ${ }^{1} \mathrm{H}-\mathrm{NMR}$ $\left(400 \mathrm{MHz}, \mathrm{CDCl}_{3}\right) \delta(\mathrm{ppm}): 9.23,9.20(2 \times 1 \mathrm{H}, 2 \mathrm{~d}, J=5.6 \mathrm{~Hz}$ in each, $2 \times \mathrm{Py}-\mathrm{H}-6), 9.02,8.98$ ( $2 \times 1 \mathrm{H}, 2 \mathrm{~s}, 2 \times$ Tria-H-5), 8.11-7.75, 7.62-7.24 (46H, m, $2 \times 20 \times$ Ar, $2 \times$ Py-H-3-Py-H-5), 6.60, $6.10\left(2 \times 1 \mathrm{H}, 2 \mathrm{pt}, J=9.4,9.3 \mathrm{~Hz}\right.$ in each, $\left.2 \times \mathrm{H}-2^{\prime}\right), 6.50,6.43(2 \times 1 \mathrm{H}, 2 \mathrm{~d}, J=9.3 \mathrm{~Hz}$ in each, $\left.2 \times \mathrm{H}^{\prime} 1^{\prime}\right), 6.22,6.15\left(2 \times 1 \mathrm{H}, 2 \mathrm{pt}, J=9.6,9.4 \mathrm{~Hz}\right.$ in each, $\left.2 \times \mathrm{H}-3^{\prime}\right), 5.97,5.94(2 \times$ $1 \mathrm{H}, 2 \mathrm{pt}, J=9.7,9.6 \mathrm{~Hz}$ in each, $\left.2 \times \mathrm{H}-4^{\prime}\right), 5.81,5.65(2), 5.57(2), 5.53,5.47,5.44(2 \times 4 \mathrm{H}, 2 \times$ $4 \mathrm{~d}, J=6.1 \mathrm{~Hz}$ in each, $2 \times 4 \times p$-cym-CH $\mathrm{Ar}), 4.78-4.52\left(2 \times 3 \mathrm{H}, \mathrm{m}, 2 \times \mathrm{H}-5^{\prime}, 2 \times \mathrm{H}-6^{\prime} \mathrm{a}\right.$, 
$\left.2 \times \mathrm{H}^{\prime} 6^{\prime} \mathrm{b}\right), 2.50,2.36(2 \times 1 \mathrm{H}, 2 \mathrm{hept}, J=6.9 \mathrm{~Hz}$ in each, $2 \times i-\mathrm{Pr}-\mathrm{CH}), 2.08,2.00(2 \times 3 \mathrm{H}$, $\left.2 \mathrm{~s}, 2 \times \mathrm{C}_{6} \mathrm{H}_{4}-\mathrm{CH}_{3}\right), 0.94,0.91,0.79,0.74(2 \times 2 \times 3 \mathrm{H}, 2 \times 2 \mathrm{~d}, J=6.9 \mathrm{~Hz}$ in each $2 \times 2 \times$ $i$-Pr- $\left.\mathrm{CH}_{3}\right) ;{ }^{13} \mathrm{C}-\mathrm{NMR}\left(100 \mathrm{MHz}, \mathrm{CDCl}_{3}\right) \delta$ (ppm): 166.3, 166.2, 165.6, 165.5, 165.2 (2), 164.9, $164.8(2 \times 4 \times \mathrm{C}=\mathrm{O}), 155.7,155.5(2 \times$ Py-C-6) $) 147.3,147.2,147.0,146.6(2 \times$ Tria-C-4, $2 \times$ Py-C-2), 140.1, 140.0 (2 × Py-C-4), 134.4, 134.2, 133.9, 133.8, 133.7 (2), 133.6, 133.5, 133.3, 130.3-128.0 (Ar), 127.2, 126.9 ( $2 \times$ Py-C-5), 126.2, 123.8 ( $2 \times$ Tria-C-5), $122.7(2 \times$ Py-C-3), 105.8, 105.3, 103.9, $102.6\left(2 \times 2 \times p\right.$-cym- $\left.\mathrm{C}_{\mathrm{qAr}}\right), 87.2,86.7\left(2 \times \mathrm{C}-1^{\prime}\right), 86.4,85.8,85.2,85.0$, 84.0, 83.9, 83.2, 82.5 $\left(2 \times 4 \times p\right.$-cym-CH $\left.\mathrm{Ar}_{\mathrm{Ar}}\right), 76.1,75.6\left(2 \times \mathrm{C}^{\prime} 5^{\prime}\right), 73.6,72.7\left(2 \times \mathrm{C}-3^{\prime}\right), 71.7$, $70.4\left(2 \times \mathrm{C}-2^{\prime}\right), 68.7,68.6\left(2 \times \mathrm{C}-4^{\prime}\right), 62.8,62.7\left(2 \times \mathrm{C}-6^{\prime}\right), 31.0(2)(2 \times i-\mathrm{Pr}-\mathrm{CH}), 22.5,22.3$, 21.7, $21.4\left(2 \times 2 \times i\right.$-Pr- $\left.\mathrm{CH}_{3}\right), 18.8,18.6\left(2 \times \mathrm{C}_{6} \mathrm{H}_{4}-\mathrm{CH}_{3}\right)$. ESI-HRMS positive mode $(\mathrm{m} / z)$ : calculated for $\mathrm{C}_{51} \mathrm{H}_{46} \mathrm{ClN}_{4} \mathrm{O}_{9} \mathrm{Ru}^{+}\left[\mathrm{M}-\mathrm{PF}_{6}\right]^{+}$995.2002. Found: 995.1994.

\subsubsection{Complex Ru-3a}

Prepared from complex Ru-dimer (50.0 mg, $0.082 \mathrm{mmol})$, compound L-3a (50.4 mg, $0.163 \mathrm{mmol}, 2$ eq.), and $\mathrm{TlPF}_{6}(57.0 \mathrm{mg}, 0.163 \mathrm{mmol})$ according to general procedure V. Yield: $107 \mathrm{mg}(90 \%)$. An analytically pure sample was obtained by recrystallization from $i \mathrm{PrOH}$ to give $20 \mathrm{mg}$ orange powder. Diastereomeric ratio: 1:1. ${ }^{1} \mathrm{H}-\mathrm{NMR}\left(400 \mathrm{MHz}, \mathrm{CD}_{3} \mathrm{OD}\right) \delta$ (ppm): 9.42 (2H, d, J = 5.4 Hz, $2 \times$ Py-H-6), 9.22, $9.21(2 \times 1 \mathrm{H}, 2 \mathrm{~s}, 2 \times$ Tria-H-5), $8.19(2 \mathrm{H}$, $\mathrm{pt}, J=7.8,7.7 \mathrm{~Hz}, 2 \times \mathrm{Py}-\mathrm{H}-4), 8.10(2 \mathrm{H}, \mathrm{d}, J=7.8 \mathrm{~Hz}, 2 \times \mathrm{Py}-\mathrm{H}-3), 7.69-7.66(2 \mathrm{H}, \mathrm{m}, 2 \times$ Py-H-5), 6.12-6.05 (4H, m, $2 \times p$-cym-CH $\left.\mathrm{Ar}_{\mathrm{Ar}}\right), 5.90-5.84\left(4 \mathrm{H}, \mathrm{m}, 2 \times p\right.$-cym- $\left.\mathrm{CH}_{\mathrm{Ar}}\right), 5.88(2 \mathrm{H}$, d, $\left.2 \times \mathrm{H}-1^{\prime}\right), 3.95-3.89\left(4 \mathrm{H}, \mathrm{m}, 2 \times \mathrm{H}-2^{\prime}, 2 \times \mathrm{H}-6^{\prime} \mathrm{a}\right), 3.77(2 \mathrm{H}, \mathrm{dd}, J=12.1,5.3 \mathrm{~Hz}, 2 \times$ H-6'b), $3.69\left(2 \mathrm{H}, \mathrm{ddd}, J=9.5,5.3,1.9 \mathrm{~Hz}, 2 \times \mathrm{H}-5^{\prime}\right), 3.64\left(2 \mathrm{H}, \mathrm{pt}, J=9.5,8.9 \mathrm{~Hz}, 2 \times \mathrm{H}-3^{\prime}\right)$, $3.56\left(2 \mathrm{H}, \mathrm{pt}, J=9.3,9.1 \mathrm{~Hz}, 2 \times \mathrm{H}-4^{\prime}\right), 2.79-2.71(2 \mathrm{H}$, hept $J=6.7 \mathrm{~Hz}, 2 \times i-\mathrm{Pr}-\mathrm{CH}), 2.22(6 \mathrm{H}$, $\left.\mathrm{s}, 2 \times \mathrm{C}_{6} \mathrm{H}_{4}-\mathrm{CH}_{3}\right), 1.18-1.09\left(12 \mathrm{H}, \mathrm{m}, 2 \times 2 \times i-\mathrm{Pr}-\mathrm{CH}_{3}\right) ;{ }^{13} \mathrm{C}-\mathrm{NMR}\left(100 \mathrm{MHz}, \mathrm{CD}_{3} \mathrm{OD}\right) \delta$ (ppm): 156.8 (2) (2 × Py-C-6), 149.6 (2), 148.2, 148.1 ( $2 \times$ Py-C-2, $2 \times$ Tria-C-4), 141.5 (2) (2 $\times$ Py-C-4), 127.6 (2) $(2 \times$ Py-C-5), 125.5, $125.2(2 \times$ Tria-C-5), 123.6 (2) $(2 \times$ Py-C-3), 106.8, 106.6, 104.1, $103.8\left(2 \times 2 \times p\right.$-cym- $\left.\left.\mathrm{C}_{\mathrm{qAr}}\right), 91.3,91.2\left(2 \times \mathrm{C}^{\prime}\right)^{\prime}\right), 87.3,87.2,86.3,86.1,85.6,85.5$, $84.8,84.6\left(2 \times 4 \times p\right.$-cym-CH $\left.\mathrm{Ar}_{\mathrm{Ar}}\right), 81.7,81.6\left(2 \times \mathrm{C}^{\prime} 5^{\prime}\right), 78.2,78.1\left(2 \times \mathrm{C}-3^{\prime}\right), 74.5,74.3(2 \times$ C-2' $), 70.8,70.7\left(2 \times \mathrm{C}^{\prime} 4^{\prime}\right), 62.3,62.2\left(2 \times \mathrm{C}^{\prime} 6^{\prime}\right), 32.3,32.2(2 \times i-\mathrm{Pr}-\mathrm{CH}), 22.6(2), 22.0,21.9$ $\left(2 \times 2 \times i-\mathrm{Pr}-\mathrm{CH}_{3}\right), 18.8,18.7\left(2 \times \mathrm{C}_{6} \mathrm{H}_{4}-\mathrm{CH}_{3}\right)$. ESI-HRMS positive mode $(\mathrm{m} / \mathrm{z})$ : calculated for $\mathrm{C}_{23} \mathrm{H}_{30} \mathrm{ClN}_{4} \mathrm{O}_{5} \mathrm{Ru}^{+}\left[\mathrm{M}-\mathrm{PF}_{6}\right]^{+}$579.0946. Found: 579.0946 .

\subsubsection{Complex Ru-3b}

Prepared from complex Ru-dimer $(50.0 \mathrm{mg}$, $0.082 \mathrm{mmol})$, compound L-3b $(58.8 \mathrm{mg}$, $0.164 \mathrm{mmol}, 2 \mathrm{eq}$.), and $\mathrm{TlPF}_{6}(57 \mathrm{mg}, 0.163 \mathrm{mmol}$ ) according to general procedure V. Yield: $121 \mathrm{mg}(96 \%)$. An analytically pure sample was obtained by recrystallization from $i \mathrm{PrOH}$ to give $34 \mathrm{mg}$ orange powder. Diastereomeric ratio: 1:1. ${ }^{1} \mathrm{H}-\mathrm{NMR}\left(400 \mathrm{MHz}, \mathrm{CD}_{3} \mathrm{OD}\right) \delta$ (ppm): 9.42, $9.41(2 \times 1 \mathrm{H}, 2 \mathrm{~s}, 2 \times$ Tria-H-5), $8.80(2 \mathrm{H}, \mathrm{d}, J=8.8 \mathrm{~Hz}, 2 \times \mathrm{Qu}-\mathrm{H}-8), 8.70,8.68$ $(2 \times 1 \mathrm{H}, 2 \mathrm{~d}, J=8.5 \mathrm{~Hz}$ in each, $2 \times \mathrm{Qu}-\mathrm{H}-4), 8.15-8.09,7.88-7.84(2 \times 4 \mathrm{H}, \mathrm{m}, \mathrm{Qu}-\mathrm{H}-3$, Qu-H-5-Qu-H-7), 6.13-5.96 $\left(2 \times 4 \mathrm{H}, \mathrm{m}, 2 \times\right.$ p-cym-CH $\left.\mathrm{Ar}_{\mathrm{Ar}}\right), 5.95,5.93(2 \times 1 \mathrm{H}, 2 \mathrm{~d}, J=9.1 \mathrm{~Hz}$ in each, $\left.2 \times \mathrm{H}-1^{\prime}\right), 4.00,3.99\left(2 \times 1 \mathrm{H}, 2 \mathrm{pt}, J=9.2,9.1 \mathrm{~Hz}\right.$ in each, $\left.2 \times \mathrm{H}-2^{\prime}\right), 3.97,3.95$ $\left(2 \times 1 \mathrm{H}, 2 \mathrm{dd}, J=12.1,2.1 \mathrm{~Hz}\right.$ in each, $\left.2 \times \mathrm{H}-6^{\prime} \mathrm{a}\right), 3.80(2 \mathrm{H}, \mathrm{dd}, J=12.1,5.3 \mathrm{~Hz}, 2 \times$ $\left.\mathrm{H}-6^{\prime} \mathrm{b}\right), 3.74,3.71\left(2 \times 1 \mathrm{H}, \mathrm{ddd}, J=9.3,5.3,2.1 \mathrm{~Hz}\right.$ in each, $\left.2 \times \mathrm{H}-5^{\prime}\right), 3.68,3.67(2 \times 1 \mathrm{H}$, $2 \mathrm{pt}, J=9.0,8.9 \mathrm{~Hz}$ in each, $\left.2 \times \mathrm{H}-3^{\prime}\right), 3.60,3.59(2 \times 1 \mathrm{H}, 2 \mathrm{pt}, J=9.3,9.2 \mathrm{~Hz}$ in each, $\left.2 \times \mathrm{H}-4^{\prime}\right), 2.48,2.46(2 \times 1 \mathrm{H}, 2 \mathrm{hept}, J=6.9 \mathrm{~Hz}$ in each, $2 \times i-\mathrm{Pr}-\mathrm{CH}), 2.20(6 \mathrm{H}, \mathrm{s}, 2 \times$ $\left.\mathrm{C}_{6} \mathrm{H}_{4}-\mathrm{CH}_{3}\right), 1.00,0.98,0.92(2)\left(2 \times 2 \times 3 \mathrm{H}, 4 \mathrm{~d}, \mathrm{~J}=6.9 \mathrm{~Hz}\right.$ in each, $\left.2 \times 2 \times i-\mathrm{Pr}-\mathrm{CH}_{3}\right) ;{ }^{13} \mathrm{C}$ NMR (90 MHz, CD $\left.{ }_{3} \mathrm{OD}\right) \delta$ (ppm): 151.0 (2), 149.7 (2), 149.1 (2), $(2 \times$ Tria-C-4, $2 \times$ Qu-C-2, $2 \times$ Qu-C-8a), $142.6(2 \times$ Qu-C-4), 134.0, 130.7, 130.6 (3), 130.5, $130.1(2 \times$ Qu-C-4a, $2 \times$ Qu-C-5-Qu-C-8), 127.1, 126.9 (2 × Tria-C-5), 119.5, $119.4(2 \times$ Qu-C-3), 106.5, 106.3, 104.9, $104.7\left(2 \times 2 \times p\right.$-cym- $\left.\mathrm{C}_{\mathrm{qAr}}\right), 91.4,91.2\left(2 \times \mathrm{C}^{\prime} \mathbf{1}^{\prime}\right), 88.6,88.5,86.5,86.3,86.2,85.8,84.6,84.3$ $\left(2 \times 4 \times p\right.$-cym-CH $\left.\mathrm{Ar}_{\mathrm{Ar}}\right), 81.8,81.7\left(2 \times \mathrm{C}-5^{\prime}\right), 78.2,78.1\left(2 \times \mathrm{C}-3^{\prime}\right), 74.4,74.3\left(2 \times \mathrm{C}-2^{\prime}\right), 70.7$ (2) $\left(2 \times \mathrm{C}-4^{\prime}\right), 62.3,62.20\left(2 \times \mathrm{C}-6^{\prime}\right), 32.3,32.2(2 \times i-\mathrm{Pr}-\mathrm{CH}), 22.7,22.6,21.6,21.5(2 \times 2$ $\times i$-Pr- $\left.\mathrm{CH}_{3}\right), 18.8,18.7\left(2 \times \mathrm{C}_{6} \mathrm{H}_{4}-\mathrm{CH}_{3}\right)$. ESI-HRMS positive mode $(\mathrm{m} / z)$ : calculated for $\mathrm{C}_{27} \mathrm{H}_{32} \mathrm{ClN}_{4} \mathrm{O}_{5} \mathrm{Ru}^{+}\left[\mathrm{M}-\mathrm{PF}_{6}\right]^{+}:$629.1103. Found: 629.1103 . 


\subsubsection{Complex Ru-4}

Prepared from complex Ru-dimer (10.0 mg, $0.016 \mathrm{mmol})$, compound L-4 (24.9 mg, $0.034 \mathrm{mmol}, 2.1 \mathrm{eq}$.$) , and \mathrm{TlPF}_{6}(11.4 \mathrm{mg}, 0.033 \mathrm{mmol})$ according to general procedure IV. After filtration and removal of the solvent, the residue was dissolved in $\mathrm{CHCl}_{3}(3 \mathrm{~mL})$, and $\mathrm{Et}_{2} \mathrm{O}(6 \mathrm{~mL})$ was added. The precipitated product was filtered off to give $28.4 \mathrm{mg}$ $(76 \%)$ yellow powder. The product could also be obtained by column chromatographic purification (9:1 $\left.\mathrm{CHCl}_{3}-\mathrm{MeOH}\right)$, albeit in lower yield (52\%). $\mathrm{R}_{\mathrm{f}}: 0.38\left(9: 1 \mathrm{CHCl}_{3}-\mathrm{MeOH}\right)$. Diastereomeric ratio: 2:1. ${ }^{1} \mathrm{H}-\mathrm{NMR}\left(400 \mathrm{MHz}, \mathrm{CDCl}_{3}\right) \delta$ (ppm): 9.50 (s, minor Py-H-6), 9.26 (s, major Py-H-6), 8.18-7.70, 7.60-7.28 (m, minor and major Ar, Py-H-3-Py-H-5), 6.19 (pt, $J=9.8,9.7 \mathrm{~Hz}$, minor $\left.\mathrm{H}-3^{\prime}\right), 6.16\left(\mathrm{pt}, J=9.8,9.5 \mathrm{~Hz}\right.$, major $\left.\mathrm{H}-2^{\prime}\right), 6.08(\mathrm{pt}, J=9.5,9.5 \mathrm{~Hz}$, major $\left.\mathrm{H}-3^{\prime}\right), 5.88\left(\mathrm{pt}, J=9.7,9.5 \mathrm{~Hz}\right.$, major $\left.\mathrm{H}-4^{\prime}\right), 5.86(\mathrm{pt}, J=9.7,9.6 \mathrm{~Hz}$, minor H-4' $), 5.90-5.84(\mathrm{~m}$, $2 \times$ minor $p$-cym- $\left.-\mathrm{CH}_{\mathrm{Ar}}\right), 5.76-5.72\left(\mathrm{~m}\right.$, major $p$-cym- $\mathrm{CH}_{\mathrm{Ar}}$, minor $\left.\mathrm{H}-2^{\prime}\right), 5.68-5.65(\mathrm{~m}, 2 \times$ minor $p$-cym- $\left.\mathrm{CH}_{\mathrm{Ar}}\right), 5.53-5.51\left(\mathrm{~m}\right.$, major $p$-cym- $\left.\mathrm{CH}_{\mathrm{Ar}}\right), 5.46\left(\mathrm{~d}, J=9.8 \mathrm{~Hz}\right.$, major $\left.\mathrm{H}-\mathrm{1}^{\prime}\right), 5.35$ $\left(\mathrm{d}, J=9.8 \mathrm{~Hz}\right.$, minor $\left.\mathrm{H}-1^{\prime}\right), 5.31-5.29\left(\mathrm{~m}, 2 \times\right.$ major $p$-cym- $\left.\mathrm{CH}_{\mathrm{Ar}}\right), 4.74-4.68(\mathrm{~m}$, minor and major $\left.\mathrm{H}-6^{\prime} \mathrm{a}\right), 4.57-4.52\left(\mathrm{~m}\right.$, minor and major $\left.\mathrm{H}-6^{\prime} \mathrm{b}\right), 4.50-4.42\left(\mathrm{~m}\right.$, minor and major $\left.\mathrm{H}-5^{\prime}\right)$, 2.78 (hept, $J=6.8 \mathrm{~Hz}$, major $i-\mathrm{Pr}-\mathrm{CH}), 2.72$ (hept, $J=6.8 \mathrm{~Hz}$, minor $i-\mathrm{Pr}-\mathrm{CH}), 2.02$ (s, minor $\left.\mathrm{C}_{6} \mathrm{H}_{4}-\mathrm{CH}_{3}\right), 1.95$ (s, major $\left.\mathrm{C}_{6} \mathrm{H}_{4}-\mathrm{CH}_{3}\right), 1.16,1.15,1.12,1.08(4 \mathrm{~d}, J=6.8 \mathrm{~Hz}$ in each, minor and major $2 \times i$-Pr- $\left.\mathrm{CH}_{3}\right) ;{ }^{13} \mathrm{C}-\mathrm{NMR}\left(90 \mathrm{MHz}, \mathrm{CDCl}_{3}\right) \delta$ (ppm): 166.2, 165.8, 165.7, 165.7, 165.3, 165.2, 165.2, 164.9, 164.8, 164.7 (minor and major C=O, OD-C-2, OD-C-5), 158.3 (minor Py-C-6), 156.6 (major Py-C-6), 140.3 (minor Py-C-4), 140.2 (major Py-C-2), 140.1 (major Py-C-4), 139.1 (minor Py-C-2), 134.6, 134.0, 133.9, 133.8, 133.7, 133.5, 133.4, 131.1, 130.6, 130.2-128.5, 127.8 (minor and major Ar, Py-C-5), 125.3 (minor Py-C-3), 125.2 (major Py-C-3), 107.0, 102.3 (minor $p$-cym- $\mathrm{C}_{\mathrm{qAr}}$ ), 104.8, 102.1 (major $p$-cym- $\mathrm{C}_{\mathrm{qAr}}$ ), 88.7, 84.6, 83.2 (2) (major $p$-cym- $\left.\mathrm{CH}_{\mathrm{Ar}}\right), 85.5,85.2,83.8,83.6\left(\right.$ minor $p$-cym- $\left.\mathrm{CH}_{\mathrm{Ar}}\right), 77.8\left(\right.$ minor $\left.\mathrm{C}-5^{\prime}\right), 77.4$ (major C-5'), 73.8, 71.5, 69.8 (major C-1'-C-3'), 72.8, 71.9, 71.4 (minor C-1'-C-3'), 68.8 (major C-4'), 68.7 (minor $\left.\mathrm{C}-4^{\prime}\right), 63.0$ (minor $\left.\mathrm{C}-6^{\prime}\right), 62.6$ (major $\left.\mathrm{C}-6^{\prime}\right)$, 31.3 (minor $\left.i-\mathrm{Pr}-\mathrm{CH}\right)$, 31.1 (major $i-\mathrm{Pr}-\mathrm{CH}$ ), 23.1, 21.3 (major $i$-Pr- $\mathrm{CH}_{3}$ ), 22.2, 22.1 (minor $i$-Pr- $\mathrm{CH}_{3}$ ), 18.8 (minor $\mathrm{C}_{6} \mathrm{H}_{4}-\mathrm{CH}_{3}$ ), 18.1 (major $\left.\mathrm{C}_{6} \mathrm{H}_{4}-\mathrm{CH}_{3}\right)$. ESI-HRMS positive mode $(\mathrm{m} / z)$ : calculated for $\mathrm{C}_{51} \mathrm{H}_{45} \mathrm{ClN}_{3} \mathrm{O}_{10} \mathrm{Ru}^{+}[\mathrm{M}-$ $\left.\mathrm{PF}_{6}\right]^{+}$996.1843; $\mathrm{C}_{53} \mathrm{H}_{52} \mathrm{~N}_{3} \mathrm{O}_{12} \mathrm{Ru}^{+}\left[\mathrm{M}-\mathrm{PF}_{6}-\mathrm{Cl}+\mathrm{OMe}+\mathrm{MeOH}\right]^{+}$1024.2604. Found: [M $\left.-\mathrm{PF}_{6}\right]^{+}$996.1861; $\left[\mathrm{M}-\mathrm{PF}_{6}-\mathrm{Cl}+\mathrm{OMe}+\mathrm{MeOH}\right]^{+}$1024.2598.

\subsubsection{Complex Ru-5}

Prepared from complex Ru-dimer $(10.0 \mathrm{mg}, 0.0163 \mathrm{mmol})$, compound L-5 (17.9 mg, $0.0375 \mathrm{mmol}, 2.3 \mathrm{eq}$.), and $\mathrm{TlPF}_{6}(11.4 \mathrm{mg}, 0.0326 \mathrm{mmol})$ according to general procedure IV. Purified by column chromatography $\left(9: 1 \mathrm{CHCl}_{3}-\mathrm{MeOH}\right)$ to give $21.7 \mathrm{mg}(74 \%)$ yellow powder. $\mathrm{R}_{\mathrm{f}}: 0.54\left(9: 1 \mathrm{CHCl}_{3}-\mathrm{MeOH}\right)$. Diastereomeric ratio: 4:3. ${ }^{1} \mathrm{H}-\mathrm{NMR}\left(400 \mathrm{MHz}, \mathrm{CDCl}_{3}\right)$ $\delta(\mathrm{ppm}): 9.45(\mathrm{~d}, J=3.9 \mathrm{~Hz}$, minor Py-H-6), $9.30(\mathrm{~d}, J=4.4 \mathrm{~Hz}$, major Py-H-6), 8.23-8.08 (m, minor and major Py-H-3, Py-H-4), 7.88 (m, minor Py-H-5), 7.80 (m, major Py-H-5), 6.01-5.96, 5.82-5.69 (m, minor and major $p$-cym-CH $\left.\mathrm{Cr}_{\mathrm{Ar}}\right), 5.75(\mathrm{pt}, J=9.7,9.6 \mathrm{~Hz}$, major H-2' $)$, $5.44,\left(\mathrm{pt}, J=9.3,9.2 \mathrm{~Hz}\right.$, minor $\left.\mathrm{H}-2^{\prime}\right), 5.40\left(\mathrm{pt}, J=9.4,9.0 \mathrm{~Hz}\right.$, minor and major $\left.\mathrm{H}-3^{\prime}\right), 5.24$ $\left(\mathrm{pt}, J=9.8,9.2 \mathrm{~Hz}\right.$, minor $\left.\mathrm{H}^{\prime} 4^{\prime}\right), 5.23\left(\mathrm{pt}, J=9.8,9.8 \mathrm{~Hz}\right.$, major $\left.\mathrm{H}-4^{\prime}\right), 5.03(\mathrm{~d}, J=10.0 \mathrm{~Hz}$, major $\left.\mathrm{H}-1^{\prime}\right), 5.00\left(\mathrm{~d}, J=8.7 \mathrm{~Hz}\right.$, minor $\left.\mathrm{H}^{-} 1^{\prime}\right), 4.30(\mathrm{dd}, J=12.8,4.8 \mathrm{~Hz}$, minor and major H-6'a), 4.17 (dd, $J=12.8,2.4 \mathrm{~Hz}$, minor and major H-6 $\left.{ }^{\prime} \mathrm{b}\right), 3.99(\mathrm{ddd}, J=10.2,4.8,2.4 \mathrm{~Hz}$, minor and major $\mathrm{H}-5^{\prime}$ ), 3.03 (hept, $J=6.8 \mathrm{~Hz}$, major $i-\mathrm{Pr}-\mathrm{CH}$ ), 2.91 (hept, $J=6.8 \mathrm{~Hz}$, minor i-Pr-CH), 2.23, 2.17, 2.10-2.02 (singlets, minor and major $\left.\mathrm{C}_{6} \mathrm{H}_{4}-\mathrm{CH}_{3}, \mathrm{COCH}_{3}\right), 1.36(\mathrm{~d}$, $J=6.8 \mathrm{~Hz}$, major $2 \times i$-Pr-CH $\left.{ }_{3}\right), 1.30,1.25\left(2 \mathrm{~d}, J=6.8 \mathrm{~Hz}\right.$ in each, minor $2 \times i$-Pr- $\left.\mathrm{CH}_{3}\right)$; ${ }^{13} \mathrm{C}-\mathrm{NMR}\left(90 \mathrm{MHz}, \mathrm{CDCl}_{3}\right) \delta(\mathrm{ppm}): 170.7,170.6,170.1,170.0,169.8,169.6,169.4(2 \times 4 \times$ $\mathrm{C}=\mathrm{O}$ ), 164.9, 164.6 (major OD-C-2, OD-C-5), 164.9, 164.7 (minor OD-C-2, OD-C-5), 157.6 (minor Py-C-6), 156.4 (major Py-C-6), 140.5 (minor Py-C-4), 140.3 (major Py-C-4), 140.3, 139.5 (minor and major Py-C-2), 130.8 (minor Py-C-5), 130.0 (major Py-C-5), 125.5 (minor Py-C-3), 125.4 (major Py-C-3), 106.4 (minor $p$-cym- $\mathrm{C}_{\mathrm{qAr}}$ ), 105.0 (major $p$-cym- $\mathrm{C}_{\mathrm{qAr}}$ ), 102.7 (minor $p$-cym- $\mathrm{C}_{\mathrm{qAr}}$ ), 102.4 (major $p$-cym- $\mathrm{C}_{\mathrm{qAr}}$ ), 88.2, 86.0, 85.6, 83.5, 83.2, 83.1 (minor and major $p$-cym-CH $\left.\mathrm{CH}_{\mathrm{Ar}}\right), 77.2$ (minor $\left.\mathrm{C}-5^{\prime}\right), 77.0$ (major $\left.\mathrm{C}-5^{\prime}\right), 73.7,70.9$ (major $\mathrm{C}-1^{\prime}$ and $\left.\mathrm{C}-3^{\prime}\right)$, 73.0, 71.2, 70.0 (minor C-1'-C-3'), 68.8 (major C-2' $), 67.7$ (minor C-4'), 67.6 (major C-4') 61.9 
(minor C-6 ${ }^{\prime}$ ), 61.7 (major C-6 ${ }^{\prime}$ ), 31.3 (minor $\left.i-P r-C H\right), 31.2$ (major $i$-Pr-CH), 22.9, 21.7 (major $i$-Pr- $\mathrm{CH}_{3}$ ), 22.4, 22.0 (minor $\left.i-\operatorname{Pr}-\mathrm{CH}_{3}\right), 20.8,20.7,20.6,20.6,20.5\left(2 \times 4 \times \mathrm{COCH}_{3}\right), 18.8$ (minor $\mathrm{C}_{6} \mathrm{H}_{4}-\mathrm{CH}_{3}$ ), 18.3 (major $\mathrm{C}_{6} \mathrm{H}_{4}-\mathrm{CH}_{3}$ ). ESI-HRMS positive mode $(\mathrm{m} / \mathrm{z}$ ): calculated for $\mathrm{C}_{31} \mathrm{H}_{37} \mathrm{ClN}_{3} \mathrm{O}_{10} \mathrm{Ru}^{+}\left[\mathrm{M}-\mathrm{PF}_{6}\right]^{+}$748.1211. Found: 748.1212.

\subsubsection{Complex Ru-6}

Prepared from complex Ru-dimer (50 mg, $0.082 \mathrm{mmol}$ ), compound L-6 (97 mg, $0.164 \mathrm{mmol}, 2$ eq.), and $\mathrm{TlPF}_{6}(57 \mathrm{mg}, 0.163 \mathrm{mmol})$ according to general procedure IV. Purified by column chromatography $\left(9: 1 \mathrm{CHCl}_{3}-\mathrm{MeOH}\right)$ to give $140 \mathrm{mg}(85 \%)$ yellow powder. $\mathrm{R}_{\mathrm{f}}$ : 0.67 (9:1 $\left.\mathrm{CHCl}_{3}-\mathrm{MeOH}\right)$. Diastereomeric ratio: 3:2. ${ }^{1} \mathrm{H}-\mathrm{NMR}\left(400 \mathrm{MHz}, \mathrm{CDCl}_{3}\right)$ $\delta$ (ppm): 9.46 (d, $J=4.1 \mathrm{~Hz}$, minor Py-H-6), 9.26 (d, J = 4.2 Hz, major Py-H-6), 8.18-7.73, 7.60-7.32 (m, minor and major Ar, Py-H-3-Py-H-5), 6.11 (pt, $J=9.1,9.1$, major H-2' ), 6.06$6.02\left(\mathrm{~m}\right.$, major and minor $\left.\mathrm{H}-3^{\prime}\right), 5.86\left(\mathrm{~d}, J=5.4 \mathrm{~Hz}\right.$, minor $p$-cym-CH $\left.\mathrm{Cr}_{\mathrm{Ar}}\right), 5.80-5.76(\mathrm{~m}$, minor and major $p$-cym-CH $\left.\mathrm{Cr}_{\mathrm{Ar}}\right), 5.74\left(\mathrm{pt}, J=9.3,9.1 \mathrm{~Hz}\right.$, minor $\left.\mathrm{H}-2^{\prime}\right), 5.65,5.63(2 \mathrm{~d}, J=6.1 \mathrm{~Hz}$ in each, minor $p$-cym-CH $\left.\mathrm{CH}_{\mathrm{Ar}}\right), 5.61-5.53\left(\mathrm{~m}\right.$, major and minor $\left.\mathrm{H}-4^{\prime}\right), 5.53(\mathrm{~d}, J=5.4 \mathrm{~Hz}$, major p-cym-CH $\left.\mathrm{Ar}_{\mathrm{Ar}}\right), 5.37-5.35\left(\mathrm{~m}\right.$, major $p$-cym-CH $\left.\mathrm{Ar}_{\mathrm{Ar}}\right), 5.28(\mathrm{~d}, J=9.1 \mathrm{~Hz}$, major H-1' $), 5.24(\mathrm{~d}$, $J=9.1 \mathrm{~Hz}$, minor $\left.\mathrm{H}-1^{\prime}\right), 4.64\left(\mathrm{dd}, J=11.8,5.1 \mathrm{~Hz}\right.$, minor $\left.\mathrm{H}_{-} 5^{\prime} \mathrm{eq}\right), 4.60$ (dd, $J=11.8,5.4 \mathrm{~Hz}$,

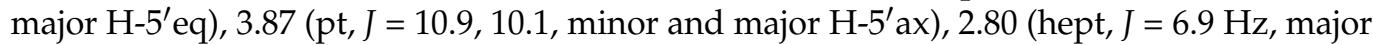
$i$-Pr-CH), 2.75 (hept, $J=6.9 \mathrm{~Hz}$, minor $i$-Pr-CH), 2.04 (s, minor $\mathrm{C}_{6} \mathrm{H}_{4}-\mathrm{CH}_{3}$ ), 1.99 (s, major $\left.\mathrm{C}_{6} \mathrm{H}_{4}-\mathrm{CH}_{3}\right), 1.19-1.11\left(\mathrm{~m}\right.$, minor and major $\left.2 \times i-\mathrm{Pr}-\mathrm{CH}_{3}\right) ;{ }^{13} \mathrm{C}-\mathrm{NMR}\left(90 \mathrm{MHz}, \mathrm{CDCl}_{3}\right) \delta$ (ppm): 165.7, 165.6 (2), 165.5, 165.4, 165.3, 165.2, 164.9, 164.7, 164.6 (minor and major $\mathrm{C}=\mathrm{O}$, OD-C-2, OD-C-5), 157.9 (minor Py-C-6), 157.0 (major Py-C-6), 140.4 (minor Py-C-4), 140.3 (major Py-C-4), 140.0 (major Py-C-2), 139.3 (minor Py-C-2), 134.4, 133.9, 133.8 (2), 133.7, 133.5, 130.8-128.0 (minor and major Ar, Py-C-5), 125.2 (minor Py-C-3), 125.1 (major Py-C-3), 106.3, 104.9, 102.4, 102.1 (minor and major $p$-cym- $\mathrm{C}_{\mathrm{qAr}}$ ), 88.4, 86.0, 85.1, 84.3, 83.5, 83.4, 83.3, 83.1 (minor and major $p$-cym- $\mathrm{CH}_{\mathrm{Ar}}$ ), 73.1, 72.1, 71.9, 71.8, 70.5, 69.7, 69.5, 69.0 (minor and major C-1'-C-4') , 67.8, 67.4 (minor and major $C-5^{\prime}$ ), 31.2, 31.0 (minor and major $i-\operatorname{Pr}-\mathrm{CH}$ ), 23.1, 22.4, 21.8, 21.1 (minor and major $i-\mathrm{Pr}-\mathrm{CH}_{3}$ ), 18.6, 18.1 (minor and major $\mathrm{C}_{6} \mathrm{H}_{4}-\mathrm{CH}_{3}$ ). ESI-HRMS positive mode $(m / z)$ : calculated for $\mathrm{C}_{43} \mathrm{H}_{39} \mathrm{ClN}_{3} \mathrm{O}_{8} \mathrm{Ru}^{+}\left[\mathrm{M}-\mathrm{PF}_{6}\right]^{+} 862.1473$; $\mathrm{C}_{45} \mathrm{H}_{46} \mathrm{~N}_{3} \mathrm{O}_{10} \mathrm{Ru}^{+}\left[\mathrm{M}-\mathrm{PF}_{6}-\mathrm{Cl}+\mathrm{OMe}+\mathrm{MeOH}\right]^{+}$890.2234. Found: $\left[\mathrm{M}-\mathrm{PF}_{6}\right]^{+}$862.1470; $\left[\mathrm{M}-\mathrm{PF}_{6}-\mathrm{Cl}+\mathrm{OMe}+\mathrm{MeOH}\right]^{+} 890.2231$.

\subsubsection{Complex Ru-7}

Prepared from complex Ru-dimer (50 mg, $0.082 \mathrm{mmol})$, compound L-7 (78 mg, $0.163 \mathrm{mmol}, 2$ eq.), and $\mathrm{TlPF}_{6}(57 \mathrm{mg}, 0.163 \mathrm{mmol})$ according to general procedure IV. Purified by column chromatography $\left(9: 1 \mathrm{CHCl}_{3}-\mathrm{MeOH}\right)$ to give $108 \mathrm{mg}(74 \%)$ yellow powder. $\mathrm{R}_{\mathrm{f}}: 0.54$ (9:1 $\left.\mathrm{CHCl}_{3}-\mathrm{MeOH}\right)$. Diastereomeric ratio: 2:1. ${ }^{1} \mathrm{H}-\mathrm{NMR}\left(400 \mathrm{MHz}, \mathrm{CDCl}_{3}\right)$ $\delta$ (ppm): 9.46 (d, J = 4.4 Hz, minor Py-H-6), 9.34 (d, J = 4.4 Hz, major Py-H-6), 8.24-8.10 (m, minor and major Py-H-4, Py-H-3), 7.87 (m, minor Py-H-5), 7.80 (m, major Py-H-5), 6.01-5.95 $\left(\mathrm{m}\right.$, minor and major $p$-cym- $\left.\mathrm{CH}_{\mathrm{Ar}}\right), 5.85$ (pt, $J=10.2,10.0 \mathrm{~Hz}$ major $\left.\mathrm{H}-2^{\prime}\right), 5.82-5.71(\mathrm{~m}$, minor and major $p$-cym- $\left.\mathrm{CH}_{\mathrm{Ar}}\right), 5.57-5.55\left(\mathrm{~m}\right.$, minor and major $\left.\mathrm{H}-4^{\prime}\right), 5.47(\mathrm{pt}, J=10.0$, $10.0 \mathrm{~Hz}$ minor H-2' $), 5.29\left(\mathrm{dd}, J=10.0,3.2 \mathrm{~Hz}\right.$, minor $\left.\mathrm{H}-3^{\prime}\right), 5.25(\mathrm{dd}, J=10.0,3.2 \mathrm{~Hz}$, major H-3 $\left.3^{\prime}\right), 5.01\left(\mathrm{~d}, J=10.2 \mathrm{~Hz}\right.$, major H-1 $\left.{ }^{\prime}\right), 4.98(\mathrm{~d}, J=10.0 \mathrm{~Hz}$, minor H-1' $), 4.23-4.10(\mathrm{~m}$, minor and major H-5' , H-6'a, H-6'b), 3.01 (hept, $J=6.8 \mathrm{~Hz}$, major $i-\operatorname{Pr}-\mathrm{CH}$ ), 2.89 (hept, $J=6.8 \mathrm{~Hz}$, minor $i$-Pr-CH), 2.24-2.23, 2.17, 2.07-2.04 (singlets, minor and major $\mathrm{C}_{6} \mathrm{H}_{4}-\mathrm{CH}_{3}, \mathrm{COCH}_{3}$ ), $1.34\left(\mathrm{~d}, J=6.8 \mathrm{~Hz}, 2 \times\right.$ major $\left.i-\operatorname{Pr}-\mathrm{CH}_{3}\right), 1.28,1.24(2 \mathrm{~d}, J=6.8 \mathrm{~Hz}$ in each, $2 \times$ minor $i$-Pr-CH$) ;{ }^{13} \mathrm{C}-\mathrm{NMR}\left(90 \mathrm{MHz}, \mathrm{CDCl}_{3}\right) \delta$ (ppm): 170.3, 170.2, 170.1, 170.0, 169.8, $169.7(2 \times 4$ $\times \mathrm{C}=\mathrm{O}$ ), 164.8, 164.7, 164.5 (2) (minor and major OD-C-2, OD-C-5), 157.4 (minor Py-C-6), 156.5 (major Py-C-6), 140.3 (minor Py-C-4), 140.1 (major Py-C-4), 139.9 (major Py-C-2), 139.2 (minor Py-C-2), 130.5 (minor Py-C-5), 129.9 (major Py-C-5), 125.3 (minor Py-C-3), 125.2 (major Py-C-3), 106.2, 102.6 (minor $p$-cym-C qAr $_{\text {) }}$, 105.1, 102.2 (major $p$-cym-C qAr $_{\text {) }}, 87.6$, 85.0, 83.1, 82.9 (major $p$-cym- $\mathrm{CH}_{\mathrm{Ar}}$ ), 85.7, 85.2, 83.3, 83.0 (minor $p$-cym-CH $\mathrm{Cr}_{\mathrm{Ar}}$ ), 75.6 (minor $\mathrm{C}-5^{\prime}$ ), 75.4 (major $\mathrm{C}-5^{\prime}$ ), 71.4, 71.0, 67.0 (major $\mathrm{C}-1^{\prime}, \mathrm{C}-3^{\prime}, \mathrm{C}-4^{\prime}$ ), 71.3, 70.7, 67.1, 66.9 (minor C-1'-C-4' $), 65.8$ (major C-2' ), 61.4 (minor C-6 ${ }^{\prime}$ ), 61.3 (major C-6 ${ }^{\prime}$ ), 31.1 (minor i-Pr-CH), 31.0 
(major $i$-Pr-CH), 22.6, 21.4 (major $i$-Pr- $\mathrm{CH}_{3}$ ), 22.2, 21.8 (minor $i-\mathrm{Pr}-\mathrm{CH}_{3}$ ), 20.6, 20.6, 20.5, 20.5, 20.4, $20.4\left(2 \times 4 \times \mathrm{COCH}_{3}\right), 18.5\left(\right.$ minor $\left.\mathrm{C}_{6} \mathrm{H}_{4}-\mathrm{CH}_{3}\right), 18.1$ (major $\left.\mathrm{C}_{6} \mathrm{H}_{4}-\mathrm{CH}_{3}\right)$. ESI-HRMS positive mode $(m / z)$ : calculated for $\mathrm{C}_{33} \mathrm{H}_{44} \mathrm{~N}_{3} \mathrm{O}_{12} \mathrm{Ru}^{+}\left[\mathrm{M}-\mathrm{PF}_{6}-\mathrm{Cl}+\mathrm{OMe}+\mathrm{MeOH}\right]^{+}$ 776.1973. Found: 776.1973.

\subsubsection{Complex Ru-8}

Prepared from complex Ru-dimer $(10.0 \mathrm{mg}, 0.0163 \mathrm{mmol})$, compound L-8 $(24.9 \mathrm{mg}$, $0.0343 \mathrm{mmol}, 2.1$ eq.), and $\mathrm{TlPF}_{6}(11.4 \mathrm{mg}, 0.0326 \mathrm{mmol})$ according to general procedure IV. Purified by column chromatography $\left(95: 5 \mathrm{CHCl}_{3}-\mathrm{MeOH}\right)$ to give $30.3 \mathrm{mg}(81 \%)$ yellow powder. $\mathrm{R}_{\mathrm{f}}$ : 0.49 (95:5 $\left.\mathrm{CHCl}_{3}-\mathrm{MeOH}\right)$. Diastereomeric ratio: 5:4. ${ }^{1} \mathrm{H}-\mathrm{NMR}(400 \mathrm{MHz}$, $\left.\mathrm{CDCl}_{3}\right) \delta(\mathrm{ppm}): 9.49(\mathrm{~d}, J=4.7 \mathrm{~Hz}$, minor Py-H-6), $9.26(\mathrm{~d}, J=5.1 \mathrm{~Hz}$, major Py-H-6), 8.21-7.25 (m, minor and major Ar, Py-H-3-Py-H-5), 6.43 (pt, $J=10.1,10.0 \mathrm{~Hz}$, major H-2'), $6.20\left(\mathrm{~d}, J=3.3 \mathrm{~Hz}\right.$, major $\left.\mathrm{H}-4^{\prime}\right), 6.16\left(\mathrm{~d}, J=2.6 \mathrm{~Hz}\right.$, minor $\left.\mathrm{H}-4^{\prime}\right), 6.02-5.94\left(\mathrm{~m}\right.$, minor $\mathrm{H}-2^{\prime}$ and $\left.\mathrm{H}-3^{\prime}\right), 5.84-5.75\left(\mathrm{~m}\right.$, minor and major $p$-cym- $\mathrm{CH}_{\mathrm{Ar}}$, major $\left.\mathrm{H}-3^{\prime}\right), 5.67,5.64(2 \mathrm{~d}, J=6.1 \mathrm{~Hz}$ in each, minor $p$-cym- $\left.\mathrm{CH}_{\mathrm{Ar}}\right) 5.52\left(\mathrm{~d}, J=6.1 \mathrm{~Hz}\right.$, major $p$-cym- $\left.-\mathrm{CH}_{\mathrm{Ar}}\right), 5.47(\mathrm{~d}, J=10.1 \mathrm{~Hz}$, major $\left.\mathrm{H}^{\prime} \mathrm{1}^{\prime}\right), 5.37\left(\mathrm{~d}, J=8.7 \mathrm{~Hz}\right.$, minor $\left.\mathrm{H}^{-} \mathrm{1}^{\prime}\right), 5.32,5.27(2 \mathrm{~d}, J=6.1 \mathrm{~Hz}$ in each, major p-cym- $-\mathrm{CH}_{\mathrm{Ar}}$ ), 4.72-4.62 (m, minor and major $\left.\mathrm{H}-5^{\prime}, \mathrm{H}-6^{\prime} \mathrm{a}\right), 4.53(\mathrm{dd}, J=10.3,4.1 \mathrm{~Hz}$, minor H-6 $\left.{ }^{\prime} \mathrm{b}\right), 4.44\left(\mathrm{dd}, J=10.3,4.0 \mathrm{~Hz}\right.$, major $\mathrm{H}-6^{\prime} \mathrm{b}$ ), 2.80 (hept, $J=6.9 \mathrm{~Hz}$, major $i-\mathrm{Pr}-\mathrm{CH}$ ), 2.73 (hept, $J=6.9 \mathrm{~Hz}$, minor $i-\mathrm{Pr}-\mathrm{CH}$ ), $2.03\left(\mathrm{~s}\right.$, minor $\left.\mathrm{C}_{6} \mathrm{H}_{4}-\mathrm{CH}_{3}\right), 1.94$ (s, major $\mathrm{C}_{6} \mathrm{H}_{4}-\mathrm{CH}_{3}$ ), 1.17, $1.15(2 \mathrm{~d}, J=6.9 \mathrm{~Hz}$ in each, $2 \times$ major $i$-Pr-CH 3$), 1.14,1.09(2 \mathrm{~d}, J=6.9 \mathrm{~Hz}$ in each, $2 \times$ minor $i$-Pr- $\left.\mathrm{CH}_{3}\right) ;{ }^{13} \mathrm{C}-\mathrm{NMR}\left(100 \mathrm{MHz}, \mathrm{CDCl}_{3}\right) \delta(\mathrm{ppm}): 166.2,166.1,165.9,165.7,165.5(2)$, 165.4, 165.3, 164.9, 164.8 (2), $164.7(2 \times 4 \times \mathrm{C}=\mathrm{O}, 2 \times$ OD-C-2, $2 \times$ OD-C-5), 157.9 (minor Py-C-6), 156.3 (major Py-C-6), 140.4 (major Py-C-2), 140.3 (minor Py-C-4), 140.2 (major Py-C-4), 139.3 (minor Py-C-2), 134.5, 134.2, 133.9, 133.8 (2), 133.6, 133.5 (2), 130.9-128.1 (minor and major Ar, Py-C-5), 125.3 (minor Py-C-3), 125.2 (major Py-C-3), 106.8, 104.7, 102.3, 102.0 (minor and major $p$-cym- $\mathrm{C}_{\mathrm{qAr}}$ ), 88.8, 85.4 (2), 84.5, 83.6, 83.5, 83.0 (2) (minor and major $p$-cym- $\mathrm{CH}_{\mathrm{Ar}}$ ), 76.7 (minor $\left.\mathrm{C}-5^{\prime}\right), 76.3$ (major $\left.\mathrm{C}-5^{\prime}\right), 72.5$ (major C-3'), 72.2 (minor $\mathrm{C}-1^{\prime}$ ), 71.7 (major C-1'), 71.3, 68.7 (minor C-2', $\left.\mathrm{C}^{\prime} 3^{\prime}\right), 68.3$ (major C-4'), 68.2 (minor C-4'), 66.8 (major C-2'), 62.4 (minor C-6 $\left.6^{\prime}\right), 62.1$ (major C-6 $\left.{ }^{\prime}\right), 31.3$ (minor $i$-Pr-CH), 31.1 (major $i-\mathrm{Pr}-\mathrm{CH}$ ), 23.2, 21.3 (major $i-\mathrm{Pr}-\mathrm{CH}_{3}$ ), 22.2, 22.0 (minor $i-\mathrm{Pr}-\mathrm{CH}_{3}$ ), 18.7 (minor $\mathrm{C}_{6} \mathrm{H}_{4}-\mathrm{CH}_{3}$ ), 18.0 (major $\left.\mathrm{C}_{6} \mathrm{H}_{4}-\mathrm{CH}_{3}\right)$. ESI-HRMS positive mode $(\mathrm{m} / z)$ : calculated for $\mathrm{C}_{51} \mathrm{H}_{45} \mathrm{ClN}_{3} \mathrm{O}_{10} \mathrm{Ru}^{+}[\mathrm{M}-$ $\left.\mathrm{PF}_{6}\right]^{+}$996.1843. Found: 996.1842.

\subsubsection{Complex Ru-9}

Prepared from complex Ru-dimer $(50 \mathrm{mg}, 0.082 \mathrm{mmol}$ ), compound L-9 $(78 \mathrm{mg}$, $0.179 \mathrm{mmol}, 2.2$ eq.), and $\mathrm{TlPF}_{6}(57 \mathrm{mg}, 0.163 \mathrm{mmol}$ ) according to general procedure IV. Purified by column chromatography $\left(9: 1 \mathrm{CHCl}_{3}-\mathrm{MeOH}\right)$ to give $130 \mathrm{mg}(94 \%)$ yellow powder. $\mathrm{R}_{\mathrm{f}}$ : 0.54 (9:1 $\left.\mathrm{CHCl}_{3}-\mathrm{MeOH}\right)$. Diastereomeric ratio: 1:1. ${ }^{1} \mathrm{H}-\mathrm{NMR}\left(400 \mathrm{MHz}, \mathrm{CDCl}_{3}\right)$ $\delta$ (ppm): $9.33(2 \mathrm{H}, \mathrm{d}, J=4.2 \mathrm{~Hz}, 2 \times$ Py-H-6), $8.15(2 \mathrm{H}, \mathrm{t}, J=7.4 \mathrm{~Hz}, 2 \times$ Py-H-4), $8.07(2 \mathrm{H}$, $\mathrm{d}, J=7.4 \mathrm{~Hz}, 2 \times \mathrm{Py}-\mathrm{H}-3), 7.79(2 \mathrm{H}, \mathrm{m}, 2 \times \mathrm{Py}-\mathrm{H}-5), 6.52,6.46(2 \times 1 \mathrm{H}, 2 \mathrm{~d}, J=2.3 \mathrm{~Hz}$ in each, $\left.2 \times \mathrm{H}^{-1}\right), 6.01-5.95\left(4 \mathrm{H}, \mathrm{m}, 2 \times p\right.$-cym-CH $\left.\mathrm{Cr}_{\mathrm{Ar}}\right), 5.84-5.71\left(6 \mathrm{H}, \mathrm{m}, 2 \times p\right.$-cym- $\mathrm{CH}_{\mathrm{Ar}}, 2$ $\left.\times \mathrm{H}^{\prime} 2^{\prime}\right), 5.34,5.30\left(2 \times 1 \mathrm{H}, 2 \mathrm{ddd}, J=8.9,4.1,2.9 \mathrm{~Hz}\right.$ in each, $\left.2 \times \mathrm{H}-3^{\prime}\right), 4.36,4.35(2 \times 1 \mathrm{H}$, $2 \mathrm{dd}, J=12.5,2.9 \mathrm{~Hz}$ in each, $\left.2 \times \mathrm{H}^{\prime} 4^{\prime} \mathrm{a}\right), 4.21,4.20(2 \times 1 \mathrm{H}, 2 \mathrm{dd}, J=12.5,4.1 \mathrm{in}$ each, 2 $\left.\times \mathrm{H}-4^{\prime} \mathrm{b}\right), 2.98,2.97(2 \times 1 \mathrm{H}, 2$ hept $J=6.9 \mathrm{~Hz}$ in each, $2 \times i-\mathrm{Pr}-\mathrm{CH}), 2.29,2.24,2.21,2.18$, 2.13, 2.12, 2.11, 2.10, 2.08, $2.08\left(30 \mathrm{H}\right.$, singlets, $\left.2 \times i-\mathrm{Pr}-\mathrm{CH}_{3}, 2 \times 4 \times \mathrm{COCH}_{3}\right), 1.33-1.29$ $\left(12 \mathrm{H}, \mathrm{m}, 2 \times 2 \times i-\mathrm{Pr}^{-} \mathrm{CH}_{3}\right) ;{ }^{13} \mathrm{C}-\mathrm{NMR}\left(90 \mathrm{MHz}, \mathrm{CDCl}_{3}\right) \delta(\mathrm{ppm}): 170.7,170.6,169.9,169.8$, 169.6, 169.5, 169.4, $169.1(2 \times 4 \times \mathrm{C}=\mathrm{O}), 165.2,165.1,164.5(2)(2 \times$ OD-C-2, $2 \times$ OD-C-5), 156.9, 156.8 (2 × Py-C-6), 140.4 (2) (2 × Py-C-4), 139.8, $139.7(2 \times$ Py-C-2), 130.3 (2) $(2 \times$ Py-C-5), 125.4, $125.3\left(2 \times\right.$ Py-C-3), 105.9, 105.7, 102.4, $102.3\left(2 \times 2 \times\right.$ p-cym-C qAr $\left._{\text {Ar }}\right), 87.2,86.6$, 85.4, 85.1, 83.5 (2), 83.4, $83.3\left(2 \times 4 \times p\right.$-cym-CH $\left.\mathrm{Cr}_{\mathrm{Ar}}\right), 68.9,68.7\left(2 \times \mathrm{C}-2^{\prime}\right), 68.0,67.8(2 \times$ C-3') , 64.3, $63.7\left(2 \times \mathrm{C}^{\prime} 1^{\prime}\right), 61.5(2)\left(2 \times \mathrm{C}-4^{\prime}\right), 31.3(2)(2 \times i-\mathrm{Pr}-\mathrm{CH}), 22.8,22.6,21.9,21.8$ $\left(2 \times 2 \times i-\mathrm{Pr}-\mathrm{CH}_{3}\right), 21.0,20.9$ (2), 20.8, 20.7, 20.6, 20.5 (2) $\left(2 \times 4 \times \mathrm{COCH}_{3}\right), 18.5,18.4(2$ $\left.\times \mathrm{C}_{6} \mathrm{H}_{4}-\mathrm{CH}_{3}\right)$. ESI-HRMS positive mode $(\mathrm{m} / z)$ : calculated for $\mathrm{C}_{29} \mathrm{H}_{35} \mathrm{ClN}_{3} \mathrm{O}_{9} \mathrm{Ru}^{+}[\mathrm{M}-$ 
$\left.\mathrm{PF}_{6}\right]^{+}$706.1105; $\mathrm{C}_{31} \mathrm{H}_{42} \mathrm{~N}_{3} \mathrm{O}_{11} \mathrm{Ru}^{+}\left[\mathrm{M}-\mathrm{PF}_{6}-\mathrm{Cl}+\mathrm{OMe}+\mathrm{MeOH}\right]^{+}$734.1866. Found: $[\mathrm{M}$ $\left.-\mathrm{PF}_{6}\right]^{+}$706.1106; $\left[\mathrm{M}-\mathrm{PF}_{6}-\mathrm{Cl}+\mathrm{OMe}+\mathrm{MeOH}\right]^{+}$734.1868.

\subsubsection{Complex Ru-10}

Prepared from complex Ru-dimer (39 mg, $0.064 \mathrm{mmol}$ ), compound L-10 (39 mg, $0.126 \mathrm{mmol}, 2 \mathrm{eq}$.), and $\mathrm{TlPF}_{6}(44 \mathrm{mg}, 0.126 \mathrm{mmol}$ ) according to general procedure $\mathrm{V}$. The crude product was triturated with $\mathrm{Et}_{2} \mathrm{O}$ to give $80 \mathrm{mg}(87 \%)$ orange powder. Diastereomeric ratio: 1:1. ${ }^{1} \mathrm{H}-\mathrm{NMR}\left(400 \mathrm{MHz}, \mathrm{CD}_{3} \mathrm{OD}\right) \delta(\mathrm{ppm}): 9.54(2 \mathrm{H}, \mathrm{d}, J=5.5 \mathrm{~Hz}, 2 \times \mathrm{Py}-\mathrm{H}-6)$, 8.40-8.36 (4H, m, $2 \times$ Py-H-3, $2 \times$ Py-H-4), 7.98-7.93 (2H, m, $2 \times$ Py-H-5), 6.19-6.13 (2 $\times$ $2 \mathrm{H}, \mathrm{m}, 2 \times p$-cym-CH $\left.\mathrm{CH}_{\mathrm{Ar}}\right), 5.94-5.92\left(2 \times 2 \mathrm{H}, \mathrm{m}, 2 \times p\right.$-cym-CH $\left.\mathrm{CH}_{\mathrm{Ar}}\right), 4.85,4.83(2 \times 1 \mathrm{H}, 2 \mathrm{~d}$, $J=9.8 \mathrm{~Hz}$ in each, $\left.2 \times \mathrm{H}^{\prime} 1^{\prime}\right), 3.92,3.91\left(2 \times 1 \mathrm{H}, 2 \mathrm{dd}, J=12.1,6.1 \mathrm{~Hz}\right.$ in each, $\left.2 \times \mathrm{H}^{-} 6^{\prime} \mathrm{a}\right)$, 3.83, $3.81\left(2 \times 1 \mathrm{H}, 2 \mathrm{pt}, J=9.5,9.3 \mathrm{~Hz}\right.$ in each, $\left.2 \times \mathrm{H}-2^{\prime}\right), 3.71,3.70(2 \times 1 \mathrm{H}, 2 \mathrm{dd}, J=12.1$, $<1 \mathrm{~Hz}$ in each, $\left.2 \times \mathrm{H}^{\prime} 6^{\prime} \mathrm{b}\right), 3.59-3.54\left(4 \mathrm{H}, \mathrm{m}, 2 \times \mathrm{H}-3^{\prime}, 2 \times \mathrm{H}^{\prime} 5^{\prime}\right), 3.45,3.45(2 \times 1 \mathrm{H}, 2 \mathrm{pt}$, $J=9.8,9.5 \mathrm{~Hz}$ in each, $\left.2 \times \mathrm{H}-4^{\prime}\right), 2.91,2.90(2 \times 1 \mathrm{H}, 2$ hept $J=6.9 \mathrm{~Hz}$ in each, $2 \times i-\mathrm{Pr}-\mathrm{CH})$, $2.23\left(6 \mathrm{H}, \mathrm{s}, 2 \times \mathrm{C}_{6} \mathrm{H}_{4}-\mathrm{CH}_{3}\right), 1.28-1.23\left(12 \mathrm{H}, \mathrm{m}, 2 \times 2 \times i-\mathrm{Pr}-\mathrm{CH}_{3}\right) ;{ }^{13} \mathrm{C}-\mathrm{NMR}(90 \mathrm{MHz}$, $\left.\mathrm{CD}_{3} \mathrm{OD}\right) \delta$ (ppm): 168.5 (2), 166.0 (2) $(2 \times$ OD-C-2, $2 \times$ OD-C-5), 158.3, 158.3 (2 $\times$ Py-C-6), 142.0 (2) (2 × Py-C-4), 141.6, 141.5 (2 × Py-C-2), 131.1 (2) $(2 \times$ Py-C-5), 126.6, 126.5 ( $2 \times$ Py-C-3), 107.3, 107.2, 103.5, $103.4\left(2 \times 2 \times\right.$ p-cym- $\left.\mathrm{C}_{\mathrm{qAr}}\right), 87.4,87.2,85.9,85.8,85.1,85.0,84.9$, $84.8\left(2 \times 4 \times\right.$ p-cym-CH $\left.\mathrm{Ar}_{\mathrm{Ar}}\right), 83.2,83.1\left(2 \times \mathrm{C}-5^{\prime}\right), 78.8,78.7\left(2 \times \mathrm{C}-3^{\prime}\right), 74.6(2)\left(2 \times \mathrm{C}-1^{\prime}\right)$, 73.3, $73.2\left(2 \times \mathrm{C}^{\prime} 2^{\prime}\right), 71.1(2)\left(2 \times \mathrm{C}^{\prime} 4^{\prime}\right), 62.6(2)\left(2 \times \mathrm{C}^{\prime} 6^{\prime}\right), 32.4(2)(2 \times i-\mathrm{Pr}-\mathrm{CH}), 22.8,22.7$, 22.1, $22.0\left(2 \times 2 \times i-\mathrm{Pr}-\mathrm{CH}_{3}\right), 18.8(2)\left(2 \times \mathrm{C}_{6} \mathrm{H}_{4}-\mathrm{CH}_{3}\right)$. ESI-HRMS positive mode $(\mathrm{m} / \mathrm{z})$ : calculated for $\mathrm{C}_{23} \mathrm{H}_{29} \mathrm{ClN}_{3} \mathrm{O}_{6} \mathrm{Ru}^{+}\left[\mathrm{M}-\mathrm{PF}_{6}\right]^{+} 580.0786$; $\mathrm{C}_{25} \mathrm{H}_{36} \mathrm{~N}_{3} \mathrm{O}_{8} \mathrm{Ru}^{+}\left[\mathrm{M}-\mathrm{PF}_{6}-\mathrm{Cl}+\right.$ $\mathrm{OMe}+\mathrm{MeOH}]^{+}$608.1548. Found: $\left[\mathrm{M}-\mathrm{PF}_{6}\right]^{+}$580.0787; $\left[\mathrm{M}-\mathrm{PF}_{6}-\mathrm{Cl}+\mathrm{OMe}+\mathrm{MeOH}\right]^{+}$ 608.1545 .

\subsubsection{Complex Ru-11}

Prepared from complex Ru-dimer (10.0 mg, $0.016 \mathrm{mmol})$, compound L-11 $(9.1 \mathrm{mg}$, $0.033 \mathrm{mmol}, 2 \mathrm{eq}$.$) , and \mathrm{TlPF}_{6}(11.4 \mathrm{mg}, 0.033 \mathrm{mmol})$ according to general procedure V. Purified by recrystallization from an $i \mathrm{PrOH}-\mathrm{Et}_{2} \mathrm{O}$ solvent mixture $(2 \mathrm{~mL}$ and $5 \mathrm{~mL}$, respectively) to give $9.5 \mathrm{mg}(42 \%)$ yellow powder. Diastereomeric ratio: 1:1. ${ }^{1} \mathrm{H}-\mathrm{NMR}$ $\left(400 \mathrm{MHz}, \mathrm{CD}_{3} \mathrm{OD}\right) \delta(\mathrm{ppm}): 9.53(2 \mathrm{H}, \mathrm{d}, J=5.4 \mathrm{~Hz}, 2 \times \mathrm{Py}-\mathrm{H}-6), 8.38-8.34(4 \mathrm{H}, \mathrm{m}, 2 \times$ Py-H-3, $2 \times$ Py-H-4), 7.95-7.92 (2H, m, $2 \times$ Py-H-5), 6.18-6.12 $\left(2 \times 2 \mathrm{H}, \mathrm{m}, 2 \times p\right.$-cym- $\left.\mathrm{CH}_{\mathrm{Ar}}\right)$, 5.94-5.90 $\left(2 \times 2 \mathrm{H}, \mathrm{m}, 2 \times p\right.$-cym- $\left.\mathrm{CH}_{\mathrm{Ar}}\right), 4.77,4.76(2 \times 1 \mathrm{H}, 2 \mathrm{~d}, J=9.6 \mathrm{~Hz}$ in each, $2 \times$ $\left.\mathrm{H}-1^{\prime}\right), 4.07,4.06\left(2 \times 1 \mathrm{H}, 2 \mathrm{dd}, J=11.1,5.3 \mathrm{~Hz}\right.$ in each, $\left.2 \times \mathrm{H}^{-} 5^{\prime} \mathrm{eq}\right), 3.81,3.80(2 \times 1 \mathrm{H}, 2 \mathrm{pt}$, $J=9.6,9.0 \mathrm{~Hz}$ in each, $\left.2 \times \mathrm{H}-2^{\prime}\right), 3.68,3.65(2 \times 1 \mathrm{H}, 2 \mathrm{ddd}, J=10.5,8.9,5.3 \mathrm{~Hz}$ in each, $2 \times$ $\left.\mathrm{H}-4^{\prime}\right), 3.51\left(2 \mathrm{H}, \mathrm{pt}, J=9.0,8.9 \mathrm{~Hz}, 2 \times \mathrm{H}-3^{\prime}\right), 3.47,3.46(2 \times 1 \mathrm{H}, 2 \mathrm{pt}, J=11.1,10.5 \mathrm{~Hz}$ in each, $\left.2 \times \mathrm{H}^{-} 5^{\prime} \mathrm{ax}\right), 2.91(2 \mathrm{H}, 2 \mathrm{hept}, J=6.8 \mathrm{~Hz}, 2 \times i-\mathrm{Pr}-\mathrm{CH}), 2.22\left(6 \mathrm{H}, \mathrm{s}, 2 \times \mathrm{C}_{6} \mathrm{H}_{4}-\mathrm{CH}_{3}\right)$, 1.28-1.23 (12H, m, $2 \times 2 \times i$-Pr-CH $\left.{ }_{3}\right) ;{ }^{13} \mathrm{C}-\mathrm{NMR}\left(100 \mathrm{MHz}, \mathrm{CD}_{3} \mathrm{OD}\right) \delta(\mathrm{ppm}): 168.8,168.6$, 166.1, $166.0(2 \times$ OD-C-2, $2 \times$ OD-C-5), 158.2 (2) $(2 \times$ Py-C-6), 142.0 (2) $(2 \times$ Py-C-4), 141.6, 141.5 ( $2 \times$ Py-C-2), 131.1 (2) $(2 \times$ Py-C-5), 126.6, 126.5 (2 $\times$ Py-C-3), 107.4 (2), 103.5, 103.4 $\left(2 \times 2 \times p\right.$-cym- $\left.\mathrm{C}_{\mathrm{qAr}}\right), 87.4,87.3,86.0,85.9,85.0(2), 84.9,84.8\left(2 \times 4 \times p\right.$-cym-CH $\left.\mathrm{Ar}_{\mathrm{Ar}}\right), 79.0$, $78.9\left(2 \times \mathrm{C}-3^{\prime}\right), 75.4,75.3\left(2 \times \mathrm{C}-1^{\prime}\right), 73.5,73.3,\left(2 \times \mathrm{C}-2^{\prime}\right), 71.8,71.7\left(2 \times \mathrm{C}-5^{\prime}\right), 70.8(2)(2 \times$ C-4'), 32.4 (2) $\left(2 \times i\right.$-Pr-CH), 22.7 (2), 22.0 (2) $\left(2 \times 2 \times i-\mathrm{Pr}-\mathrm{CH}_{3}\right), 18.7(2)\left(2 \times \mathrm{C}_{6} \mathrm{H}_{4}-\mathrm{CH}_{3}\right)$. ESI-HRMS positive mode $(\mathrm{m} / z)$ : calculated for $\mathrm{C}_{22} \mathrm{H}_{27} \mathrm{ClN}_{3} \mathrm{O}_{5} \mathrm{Ru}^{+}\left[\mathrm{M}-\mathrm{PF}_{6}\right]^{+}$550.0680; $\mathrm{C}_{24} \mathrm{H}_{34} \mathrm{~N}_{3} \mathrm{O}_{7} \mathrm{Ru}^{+}\left[\mathrm{M}-\mathrm{PF}_{6}-\mathrm{Cl}+\mathrm{OMe}+\mathrm{MeOH}\right]^{+}$578.1442. Found: $\left[\mathrm{M}-\mathrm{PF}_{6}\right]^{+}$550.0672; $\left[\mathrm{M}-\mathrm{PF}_{6}-\mathrm{Cl}+\mathrm{OMe}+\mathrm{MeOH}\right]^{+} 578.1432$.

\subsubsection{Complex Ru-12}

Prepared from complex Ru-dimer $(10.0 \mathrm{mg}, 0.016 \mathrm{mmol})$, compound L-12 (10.1 mg, $0.033 \mathrm{mmol}, 2 \mathrm{eq}$.$) , and \mathrm{TlPF}_{6}(11.4 \mathrm{mg}, 0.033 \mathrm{mmol})$ according to general procedure V. Purified by recrystallization from an $i \mathrm{PrOH}-\mathrm{Et}_{2} \mathrm{O}$ solvent mixture $(2 \mathrm{~mL}$ and $5 \mathrm{~mL}$, respectively) to give $11.9 \mathrm{mg}$ (50\%) yellow powder. Diastereomeric ratio: 1:1. ${ }^{1} \mathrm{H}-\mathrm{NMR}$ (360 MHz, CD $\left.{ }_{3} \mathrm{OD}\right) \delta(\mathrm{ppm}): 9.55(2 \mathrm{H}, \mathrm{d}, J=5.6 \mathrm{~Hz}, 2 \times \mathrm{Py}-\mathrm{H}-6), 8.40-8.35(4 \mathrm{H}, \mathrm{m}, 2 \times$ Py-H-3, $2 \times$ Py-H-4), 7.96-7.93 (2H, m, $2 \times$ Py-H-5), 6.19-6.13 $\left(2 \times 2 \mathrm{H}, \mathrm{m}, 2 \times p\right.$-cym- $\left.\mathrm{CH}_{\mathrm{Ar}}\right)$, 
5.94-5.92 $\left(2 \times 2 \mathrm{H}, \mathrm{m}, 2 \times p\right.$-cym-CH $\left.\mathrm{Cr}_{\mathrm{Ar}}\right), 4.78,4.76(2 \times 1 \mathrm{H}, 2 \mathrm{~d}, J=9.8 \mathrm{~Hz}$ in each, $2 \times$ $\left.\mathrm{H}-1^{\prime}\right), 4.18,4.15\left(2 \times 1 \mathrm{H}, 2 \mathrm{pt}, J=9.8,9.4\right.$ in each, $\left.2 \times \mathrm{H}-2^{\prime}\right), 4.01(2 \mathrm{H}, \mathrm{d}, J=3.2 \mathrm{~Hz}, 2 \times$ $\left.\mathrm{H}-4^{\prime}\right), 3.84-3.73\left(6 \mathrm{H}, \mathrm{m}, 2 \times \mathrm{H}-5^{\prime}, 2 \times \mathrm{H}^{\prime} 6^{\prime} \mathrm{a}, 2 \times \mathrm{H}-6^{\prime} \mathrm{b}\right), 3.69,3.68(2 \times 1 \mathrm{H}, 2 \mathrm{dd}, J=9.4,3.2$ in each, $\left.2 \times \mathrm{H}^{\prime} 3^{\prime}\right), 2.91\left(2 \mathrm{H}, 2\right.$ hept, $J=6.9 \mathrm{~Hz}, 2 \times i$-Pr-CH), $2.23\left(6 \mathrm{H}, \mathrm{s}, 2 \times \mathrm{C}_{6} \mathrm{H}_{4}-\mathrm{CH}_{3}\right)$, 1.27-1.23 (12H, m, $2 \times 2 \times i$-Pr-CH3); ${ }^{13} \mathrm{C}-\mathrm{NMR}\left(90 \mathrm{MHz}, \mathrm{CD}_{3} \mathrm{OD}\right) \delta$ (ppm): 168.7, 168.6, 166.0, 165.9 (2 × OD-C-2, $2 \times$ OD-C-5), 158.1 (2) (2 × Py-C-6), 141.9 (2) (2 × Py-C-4), 141.6, 141.5 (2 × Py-C-2), 131.1 (2) (2 × Py-C-5), 126.5, 126.4 (2 × Py-C-3), 107.4, 107.3, 103.5, 103.4 $\left(2 \times 2 \times p\right.$-cym- $\left.\mathrm{C}_{\mathrm{qAr}}\right), 87.2,87.1,86.0,85.8,85.0(2), 84.8,84.7\left(2 \times 4 \times p\right.$-cym-CH $\left.\mathrm{Ar}_{\mathrm{Ar}}\right), 82.0$, $81.9\left(2 \times{\mathrm{C}-5^{\prime}}^{\prime}\right), 75.6,75.5,75.1,75.0\left(2 \times \mathrm{C}-1^{\prime}, 2 \times \mathrm{C}-3^{\prime}\right), 70.6,70.5,70.2,70.0\left(2 \times \mathrm{C}-2^{\prime}, 2 \times\right.$ $\left.\mathrm{C}-4^{\prime}\right), 62.7$ (2) $\left(2 \times \mathrm{C}^{\prime} 6^{\prime}\right), 32.4(2)(2 \times i-\mathrm{Pr}-\mathrm{CH}), 22.7,22.6,22.1,22.0\left(2 \times 2 \times i-\mathrm{Pr}-\mathrm{CH}_{3}\right), 18.7$ (2) $\left(2 \times \mathrm{C}_{6} \mathrm{H}_{4}-\mathrm{CH}_{3}\right)$. ESI-HRMS positive mode $(\mathrm{m} / z)$ : calculated for $\mathrm{C}_{23} \mathrm{H}_{29} \mathrm{ClN}_{3} \mathrm{O}_{6} \mathrm{Ru}^{+}$ $\left[\mathrm{M}-\mathrm{PF}_{6}\right]^{+}$580.0786; $\mathrm{C}_{25} \mathrm{H}_{36} \mathrm{~N}_{3} \mathrm{O}_{8} \mathrm{Ru}^{+}\left[\mathrm{M}-\mathrm{PF}_{6}-\mathrm{Cl}+\mathrm{OMe}+\mathrm{MeOH}\right]^{+}$608.1548. Found: $\left[\mathrm{M}-\mathrm{PF}_{6}\right]^{+}$580.0792; $\left[\mathrm{M}-\mathrm{PF}_{6}-\mathrm{Cl}+\mathrm{OMe}+\mathrm{MeOH}\right]^{+}$608.1553.

\subsubsection{Complex Ru-13}

Prepared from complex Ru-dimer (20.0 mg, $0.033 \mathrm{mmol}), 1$-phenyl-4-(pyridine-2-yl)1,2,3-triazole [34] (L-13, $14.5 \mathrm{mg}, 0.065 \mathrm{mmol}, 2$ eq.), and TlPF 6 (22.8 mg, $0.065 \mathrm{mmol})$ according to general procedure V. Purified by recrystallization from a $\mathrm{CHCl}_{3}-\mathrm{Et}_{2} \mathrm{O}$ solvent mixture ( $3 \mathrm{~mL}$ and $6 \mathrm{~mL}$, respectively) to give $36.8 \mathrm{mg}(88 \%)$ yellow powder. Racemic mixture. ${ }^{1} \mathrm{H}-\mathrm{NMR}\left(400 \mathrm{MHz}\right.$, acetone- $\left.d_{6}\right) \delta(\mathrm{ppm}): 9.62(1 \mathrm{H}, \mathrm{s}, \mathrm{Tria}-\mathrm{H}-5), 9.57(1 \mathrm{H}, \mathrm{ddd}$, $J=5.6,1.4,0.9 \mathrm{~Hz}$, Py-H-6), 8.29 (1H, dt, $J=7.6,1.4 \mathrm{~Hz}, \mathrm{Py}-\mathrm{H}-4), 8.25$ (1H, ddd, $J=7.9$, 1.9, 0.9 Hz, Py-H-3), 8.12-8.09 (2H, m, Ph), 7.79-7.68 (4H, m, Ph, Py-H-5), 6.27, 6.24, 6.04, $5.99\left(4 \times 1 \mathrm{H}, 4 \mathrm{~d}, J=6.2 \mathrm{~Hz}\right.$ in each, $4 \times p$-cym-CH $\left.\mathrm{CHr}_{\mathrm{Ar}}\right), 2.91(1 \mathrm{H}$, hept, $J=6.9 \mathrm{~Hz}, i-\mathrm{Pr}-\mathrm{CH})$, $2.29\left(3 \mathrm{H}, \mathrm{s}, \mathrm{C}_{6} \mathrm{H}_{4}-\mathrm{CH}_{3}\right), 1.23,1.19\left(2 \times 3 \mathrm{H}, 2 \mathrm{~d}, J=6.9 \mathrm{~Hz}\right.$ in each, $\left.2 \times i-\mathrm{Pr}-\mathrm{CH}_{3}\right) ;{ }^{13} \mathrm{C}-\mathrm{NMR}$ (90 MHz, acetone- $\left.d_{6}\right) \delta(\mathrm{ppm}): 156.6$ (Py-C-6), 149.2, 148.2 (Tria-C-4, Py-C-2), 141.1 (Py-C-4), 131.6, 131.2, 127.3, 124.0, 123.3, 121.9 (Ph, Py-C-3, Py-C-5, Tria-C-5), 106.2, 103.4 (2 × p-cym$\left.\mathrm{C}_{\mathrm{qAr}}\right), 87.4,85.8,85.1,84.5\left(4 \times p\right.$-cym-CH $\left.\mathrm{Ar}_{\mathrm{Ar}}\right), 31.9(i-\mathrm{Pr}-\mathrm{CH}), 22.6,21.9\left(2 \times i-\mathrm{Pr}-\mathrm{CH}_{3}\right), 18.7$ $\left(\mathrm{C}_{6} \mathrm{H}_{4}-\mathrm{CH}_{3}\right)$. ESI-HRMS positive mode $(\mathrm{m} / z)$ : calculated for $\mathrm{C}_{23} \mathrm{H}_{24} \mathrm{ClN}_{4} \mathrm{Ru}^{+}\left[\mathrm{M}-\mathrm{PF}_{6}\right]^{+}$: 493.0730. Found: 493.0709.

\subsubsection{Complex Ru-14}

Prepared from complex Ru-dimer (20.0 mg, $0.033 \mathrm{mmol}), 2$-phenyl-5-(pyridine-2-yl)1,3,4-oxadiazole [35,36] (L-14, $14.6 \mathrm{mg}, 0.065 \mathrm{mmol}, 2$ eq.), and TlPF 6 (22.8 mg, $0.065 \mathrm{mmol})$ according to general procedure V. Purified by recrystallization from a $\mathrm{CHCl}_{3}-\mathrm{Et}_{2} \mathrm{O}$ solvent mixture ( $3 \mathrm{~mL}$ and $6 \mathrm{~mL}$, respectively) to give $34.9 \mathrm{mg}(84 \%)$ yellow powder. Racemic mixture. ${ }^{1} \mathrm{H}-\mathrm{NMR}\left(360 \mathrm{MHz}\right.$, acetone- $\left.d_{6}\right) \delta(\mathrm{ppm}): 9.69(1 \mathrm{H}, \mathrm{ddd}, J=5.6,1.3,0.8 \mathrm{~Hz}$, Py-H-6), 8.54 (1H, ddd, J = 7.8, 1.6, 0.8 Hz, Py-H-3), 8.48 (1H, dt, J = 7.8, 1.3 Hz, Py-H-4), 8.33-8.29 (2H, m, Ph), 8.01 (1H, ddd, $J=7.8,5.6,1.6$ Hz, Py-H-5), 7.85-7.72 (3H, m, Ph), 6.30-6.27, 6.07-6.04 (2 × 2H, $2 \mathrm{~m}, 4 \times p$-cym-CH $\mathrm{Ar}), 3.03(1 \mathrm{H}$, hept, $J=6.9 \mathrm{~Hz}, i-\mathrm{Pr}-\mathrm{CH})$, $2.31\left(3 \mathrm{H}, \mathrm{s}, \mathrm{C}_{6} \mathrm{H}_{4}-\mathrm{CH}_{3}\right), 1.32,1.30\left(2 \times 3 \mathrm{H}, 2 \mathrm{~d}, \mathrm{~J}=6.9 \mathrm{~Hz}\right.$ in each, $\left.2 \times i-\mathrm{Pr}-\mathrm{CH}_{3}\right) ;{ }^{13} \mathrm{C}-\mathrm{NMR}$ (90 MHz, acetone- $d_{6}$ ) $\delta$ (ppm): 168.2, 164.7 (OD-C-2, OD-C-5), 157.8 (Py-C-6), 141.6 (Py-C-4), 141.5 (Py-C-2), 134.9, 130.7, 130.3, 128.5, 125.9, 122.7 (Ph, Py-C-3, Py-C-5), 106.7, $102.9(2 \times$ p-cym- $\left.\mathrm{C}_{\mathrm{qAr}}\right), 86.9,85.6,84.7,84.5\left(4 \times p\right.$-cym- $\left.\mathrm{CH}_{\mathrm{Ar}}\right), 32.0(i-\mathrm{Pr}-\mathrm{CH}), 22.7,22.0\left(2 \times i-\mathrm{Pr}-\mathrm{CH}_{3}\right)$, $18.8\left(\mathrm{C}_{6} \mathrm{H}_{4}-\mathrm{CH}_{3}\right)$. ESI-HRMS positive mode $(\mathrm{m} / z)$ : calculated for $\mathrm{C}_{23} \mathrm{H}_{23} \mathrm{ClN}_{3} \mathrm{ORu}^{+}[\mathrm{M}-$ $\left.\mathrm{PF}_{6}\right]^{+}:$494.0556. Found: 494.0553.

\subsection{Determination of the Distribution Coefficients $(\log D)$}

Prior to the experiments, $n$-octanol was saturated with aqueous PBS solution $(\mathrm{pH}=7.40)$ and vice versa. The corresponding complex (approximately $0.2-0.3 \mathrm{mg}$ ) was dissolved in a mixture of $2.50 \mathrm{~mL}$ of pre-saturated $n$-octanol and $2.50 \mathrm{~mL}$ of pre-saturated PBS buffer, and the mixture was vigorously stirred for 3 days. According to the NMR stability measurements, this time was necessary to reach equilibrium between the various ionic complex species. Due to the lipophilic/hydrophilic character of the complexes, those with benzoyl protection or the non-sugar derivative could mostly be found in the $n$ - 
octanol, while the acetyl and non-protected complexes could be found in the aqueous PBS phase. The appropriate separated solution was centrifuged (ScanSpeed 406G instrument, 4000 RPM for $5 \mathrm{~min}$ ), and the absorption of the "stock solution" was measured (VWR UV-1600PC Spectrophotometer, $270-420 \mathrm{~nm}$ ). Then $2.00 \mathrm{~mL}$ of stock solution was stirred vigorously with $16.00 \mathrm{~mL}$ of pre-saturated, clean $n$-octanol or PBS solution. After 1 day, the phases were separated and centrifuged, and the absorption of the solution was measured again. From the absorption difference of the stock solutions, the distribution coefficient (D) was calculated according to the previously described formulae [66].

\subsection{Visualization}

All structures were drawn using Chemdraw Professional 17.0.

\subsection{Cell Culture Materials and the Source of the Platinum Compounds}

Carboplatin, oxaliplatin, cisplatin, rucaparib, Trolox, and MitoTempo were from Sigma-Aldrich (St. Louis, MO, USA). All other materials for cellular experiments were from Sigma-Aldrich, unless otherwise stated.

\subsection{Cell Culture}

Cells were cultured under standard cell culture conditions, $37^{\circ} \mathrm{C}, 5 \% \mathrm{CO}_{2}$, humidified atmosphere. A2780 cells were cultured in RMPI 1640 medium supplemented with $10 \%$ fetal calf serum, $2 \mathrm{mM}$ glutamine, and 1\% penicillin-streptomycin (Sigma-Aldrich). ID8 cells were cultured in high-glucose DMEM ( $4.5 \mathrm{~g} / \mathrm{L}$ glucose) supplemented with $4 \%$ fetal calf serum, $2 \mathrm{mM}$ glutamine, 1\% penicillin-streptomycin (Sigma-Aldrich), and 1\% ITS supplement (Sigma-Aldrich I3146). U251 cells were maintained in MEM (Sigma-Aldrich), $10 \%$ fetal bovine serum (Sigma-Aldrich), 1\% penicillin/streptomycin (Invitrogene), and $2 \mathrm{mM}$ glutamine. MCF7 cells were maintained in MEM (Sigma-Aldrich), 10\% fetal bovine serum (Sigma-Aldrich), 1\% penicillin/streptomycin (Invitrogen, Waltham, MA, USA), and $2 \mathrm{mM}$ glutamine. Capan2 cells were maintained in MEM (Sigma-Aldrich), 10\% fetal bovine serum (Sigma-Aldrich), 1\% penicillin/streptomycin (Invitrogen), and $2 \mathrm{mM}$ glutamine. Human primary dermal fibroblasts were cultured in low-glucose DMEM $(1 \mathrm{~g} / \mathrm{L}$ glucose $)$ supplemented with $20 \%$ fetal calf serum, $2 \mathrm{mM}$ glutamine, and $1 \%$ penicillin-streptomycin (Sigma-Aldrich).

\subsection{Methylthiazolyldiphenyl-Tetrazolium Bromide (MTT) Reduction Assay}

The MTT reduction assay assesses the activity of mitochondrial complex I, and it was used to assess rapid toxicity. The MTT reduction assay was performed similarly to [67]. Cells were seeded in 96-well plates. The next day, cells were treated with the compounds for $4 \mathrm{~h}$ in the concentrations indicated in a cell incubator. At the end of treatment, MTT was added in $0.5 \mathrm{mg} / \mathrm{mL}$ final concentration, and cells were incubated at $37^{\circ} \mathrm{C}$ in a cell incubator. Then, culture media was removed, the reduced MTT dye was resolved in dimethyl sulfoxide (DMSO), and plates were measured in a plate photometer (Thermo Scientific Multiscan GO spectrophotometer, Waltham, MA, USA) at $540 \mathrm{~nm}$. On each plate, wells were designed to contain untreated/vehicle-treated cells. In calculations, the readings for these wells were considered as 1 , and all readings were expressed relative to these values.

\subsection{Sulforhodamine B (SRB) Proliferation Assay}

The SRB accumulation assay assesses protein content in a sample, and it was used to assess cell proliferation. The SRB accumulation assay was performed similarly to [68]. Cells were seeded in 96-well plates. The next day, cells were treated with the compounds for $48 \mathrm{~h}$ in the concentrations indicated in a cell incubator. At the end of treatment, cells were fixed with $10 \%$ trichloroacetic acid (TCA). Fixed cells were stained with SRB $(0.4 \%$ $\mathrm{m} / \mathrm{v}$ dissolved in $1 \%$ acetic acid) for $60 \mathrm{~min}$. Fixed cells were washed in $1 \%$ acetic acid three times; acetic acid was removed, and cells were left to dry. Protein-bound SRB was 
released by adding $100 \mu \mathrm{L}$ of $10 \mathrm{mM}$ Tris base. Plates were measured in a plate photometer (Thermo Scientific Multiscan GO spectrophotometer, Waltham, MA, USA) at $540 \mathrm{~nm}$. On each plate, wells were designed to contain untreated cells. In calculations, the readings for these wells were considered as 1 , and all readings were expressed relative to these values.

\subsection{Annexin V-FITC, PI Double Staining}

Annexin V-PI double staining was applied to assess apoptotic and necrotic cell death similar to $[37,38,69]$. A2780 cells were treated with the indicated compounds at the concentration corresponding to their $\mathrm{IC}_{50}$ value for 2,4 , and $48 \mathrm{~h}$. The 4 and $48 \mathrm{~h}$ time points correspond to the time points for the MTT and SRB assays, while the $2 \mathrm{~h}$ time point reflects the optimum time point for the detection of apoptotic or necrotic cell death [37,38,69]. Quadrants were set on the basis of the FITC and PI values observed for the vehicle-treated cells.

\subsection{Western Blotting}

The preparation of protein extracts, the separation of protein extracts in SDS-polyacrylamide gel electrophoresis, and the subsequent Western blotting were performed as described in [70] using the antibodies in Table 4. Enhanced chemiluminescence was developed using ChemiDoc Imager, (Bio-Rad, Hercules, CA, USA). Densitometry was performed using Image Lab Touch Software, Bio-Rad, Hercules, CA, USA).

Table 4. The list of antibodies used in the current study.

\begin{tabular}{cccc}
\hline Antibody & Company & Catalog Number & Dilution \\
\hline 4-Hydroxynonenal (4HNE) & Abcam & ab46545 & $1: 1000$ \\
\hline Anti-mouse IgG, HRP-linked & Sigma-Aldrich & A9044 & $1: 2000$ \\
\hline Anti-rabbit IgG, HRP-linked & Cell Signaling Technology & 7074 & $1: 2000$ \\
\hline Anti- $\beta$-actin-Peroxidase & Sigma-Aldrich & A3854 & $1: 20,000$ \\
\hline
\end{tabular}

\subsection{Statistical Analysis}

Statistical analysis was performed using Graphpad Prism version 8.0.1. Values were tested for normal distribution using the D'Agostino and Pearson normality test. When necessary, values were log-normalized or were normalized using the Box-Cox normalization method [71], as indicated in the figure captions. The level of significance of the subsequent statistical test and post hoc test is indicated in the figure captions. Nonlinear regression was performed using the built-in "[Inhibitor] vs. response-variable slope (four parameters), least square fit" utility of Graphpad that yielded $\mathrm{IC}_{50}$ and Hill slope values.

Supplementary Materials: The following are available online at https:/ / www.mdpi.com/article/10 $.3390 /$ ijms221910454/s1, Table S1. Selected ${ }^{1} \mathrm{H}-\mathrm{NMR}$ data of Ru-dimer, the 1-( $\beta$-D-glucopyranosyl)4-hetaryl-1,2,3-triazoles (L-1-L-3), and their half-sandwich Ru(II) complexes (Ru-1-Ru-3); Table S2. Changes in the chemical shifts of selected ${ }^{1} \mathrm{H}-\mathrm{NMR}$ resonances as a result of the complex formation for Ru-1-Ru-3; Table S3. Selected ${ }^{13} \mathrm{C}-\mathrm{NMR}$ data of Ru-dimer, the 1-( $\beta$-D-glucopyranosyl)-4-hetaryl1,2,3-triazoles (L-1-L-3) and their half-sandwich Ru(II) complexes (Ru-1-Ru-3); Table S4. Changes in the chemical shifts of selected ${ }^{13} \mathrm{C}-\mathrm{NMR}$ resonances as a result of the complex formation for Ru-1-Ru-3; Table S5. Selected ${ }^{1} \mathrm{H}-\mathrm{NMR}$ data of Ru-dimer, the monosaccharide-based 5-(pyridine-2yl)-1,3,4-oxadiazoles (L-4-L-12), and their half-sandwich Ru(II) complexes (Ru-4-Ru-12); Table S6. Changes in the chemical shifts of selected ${ }^{1} \mathrm{H}-\mathrm{NMR}$ resonances as a result of the complex formation for Ru-4-Ru-12; Table S7. Selected ${ }^{13}$ C-NMR data of Ru-dimer, the monosaccharide-based 5-(pyridine2-yl)-1,3,4-oxadiazoles (L-4-L-12), and their half-sandwich Ru(II) complexes (Ru-4-Ru-12); Table S8. Changes in the chemical shifts of selected ${ }^{13} \mathrm{C}-\mathrm{NMR}$ resonances as a result of the complex formation for Ru-4-Ru-12, along with copies of ${ }^{1} \mathrm{H}$ - and ${ }^{13} \mathrm{C}-\mathrm{NMR}$ spectra; Figure S1. A representative example for the stability of the complexes in aqueous medium; Table S9. Distribution coefficient of the synthesized complexes $(\log \mathrm{D})$. 
Author Contributions: I.K. synthesized the compounds and performed the stability and lipophilicity experiments; A.S. performed cell-based assays, statistical analysis, and visualization; G.U. performed cell-based assays; P.B. (Péter Buglyó) contributed to the structural analysis of the complexes and coordinated the stability and lipophilicity experiments; L.S. wrote the paper and contributed to the manuscript editing; P.B. (Péter Bai) conceptualized and coordinated and supervised the research, contributed to visualization, and wrote the paper; É.B. conceptualized the research, coordinated the synthetic work, and wrote the paper. All authors have read and agreed to the published version of the manuscript.

Funding: Our work was supported by the National Research, Development, and Innovation Office of Hungary (grants K123975 and FK125067), by the EU co-financed by the European Regional Development Fund under projects GINOP-2.3.2-15-2016-00006, GINOP-2.3.2-15-2016-00008, and GINOP-2.3.3-15-2016-00004, by the Momentum fellowship of the Hungarian Academy of Sciences and the University of Debrecen, and by the Thematic Excellence Program (TKP2020-IKA-04) of the Ministry for Innovation and Technology in Hungary.

Institutional Review Board Statement: Not applicable.

Informed Consent Statement: Not applicable.

Data Availability Statement: Primary biological data for this manuscript are available at https: / / figshare.com/s/83d6f7cf80102ce05c2c (accessed on 16 September 2021). (DOI:10.6084/m9.figshare. 13024601).

Acknowledgments: We are grateful for László Finta for the technical assistance, as well as Attila Tóth and Eszter Janka (both at the University of Debrecen) for their advice and help with statistical calculations.

Conflicts of Interest: The authors declare no conflict of interest.

\section{References}

1. Yu, C.; Wang, Z.; Sun, Z.; Zhang, L.; Zhang, W.; Xu, Y.; Zhang, J.J. Platinum-Based Combination Therapy: Molecular Rationale, Current Clinical Uses, and Future Perspectives. J. Med. Chem. 2020, 63, 13397-13412. [CrossRef]

2. McMullen, M.; Madariaga, A.; Lheureux, S. New approaches for targeting platinum-resistant ovarian cancer. Semin. Cancer Biol. 2020. [CrossRef]

3. Mukherjea, D.; Dhukhwa, A.; Sapra, A.; Bhandari, P.; Woolford, K.; Franke, J.; Ramkumar, V.; Rybak, L. Strategies to reduce the risk of platinum containing antineoplastic drug-induced ototoxicity. Expert Opin. Drug Metab. Toxicol. 2020, 16, 965-982. [CrossRef] [PubMed]

4. Manohar, S.; Leung, N. Cisplatin nephrotoxicity: A review of the literature. J. Nephrol. 2018, 31, 15-25. [CrossRef]

5. Holditch, S.J.; Brown, C.N.; Lombardi, A.M.; Nguyen, K.N.; Edelstein, C.L. Recent Advances in Models, Mechanisms, Biomarkers, and Interventions in Cisplatin-Induced Acute Kidney Injury. Int. J. Mol. Sci. 2019, 20, 3011. [CrossRef] [PubMed]

6. Kenny, R.G.; Marmion, C.J. Toward Multi-Targeted Platinum and Ruthenium Drugs-A New Paradigm in Cancer Drug Treatment Regimens? Chem. Rev. 2019, 119, 1058-1137. [CrossRef] [PubMed]

7. Graf, N.; Lippard, S.J. Redox activation of metal-based prodrugs as a strategy for drug delivery. Adv. Drug Deliv. Rev. 2012, 64, 993-1004. [CrossRef]

8. Yadav, A.; Janaratne, T.; Krishnan, A.; Singhal, S.S.; Yadav, S.; Dayoub, A.S.; Hawkins, D.L.; Awasthi, S.; MacDonnell, F.M. Regression of lung cancer by hypoxia-sensitizing ruthenium polypyridyl complexes. Mol. Cancer Ther. 2013, 12, 643-653. [CrossRef]

9. Mihajlovic, K.; Milosavljevic, I.; Jeremic, J.; Savic, M.; Sretenovic, J.; Srejovic, I.M.; Zivkovic, V.I.; Jovicic, N.; Paunovic, M.; Bolevich, S.; et al. Redox and apoptotic potential of novel ruthenium complexes in the rat blood and heart. Can. J. Physiol. Pharmacol. 2020. [CrossRef]

10. Liu, J.; Lai, H.; Xiong, Z.; Chen, B.; Chen, T. Functionalization and cancer-targeting design of ruthenium complexes for precise cancer therapy. Chem. Commun. 2019, 55, 9904-9914. [CrossRef]

11. Gano, L.; Pinheiro, T.; Matos, A.P.; Tortosa, F.; Jorge, T.F.; Gonçalves, M.S.; Martins, M.; Morais, T.S.; Valente, A.; Tomaz, A.I.; et al. Antitumour and Toxicity Evaluation of a Ru(II)-Cyclopentadienyl Complex in a Prostate Cancer Model by Imaging Tools. Anticancer Agents Med. Chem. 2019, 19, 1262-1275. [CrossRef] [PubMed]

12. Mello-Andrade, F.; Cardoso, C.G.; Silva, C.R.E.; Chen-Chen, L.; Melo-Reis, P.R.; Lima, A.P.; Oliveira, R.; Ferraz, I.B.M.; Grisolia, C.K.; Almeida, M.A.P.; et al. Acute toxic effects of ruthenium (II)/amino acid/diphosphine complexes on Swiss mice and zebrafish embryos. Biomed. Pharmacother. 2018, 107, 1082-1092. [CrossRef] [PubMed]

13. Meier-Menches, S.M.; Gerner, C.; Berger, W.; Hartinger, C.G.; Keppler, B.K. Structure-activity relationships for ruthenium and osmium anticancer agents-Towards clinical development. Chem. Soc. Rev. 2018, 47, 909-928. [CrossRef] [PubMed] 
14. Zeng, L.; Gupta, P.; Chen, Y.; Wang, E.; Ji, L.; Chao, H.; Chen, Z.-S. The development of anticancer ruthenium(II) complexes: From single molecule compounds to nanomaterials. Chem. Soc. Rev. 2017, 46, 5771-5804. [CrossRef] [PubMed]

15. Fernandes, A.C. Synthesis, Biological Activity and Medicinal Applications of Ruthenium Complexes Containing Carbohydrate Ligands. Curr. Med. Chem. 2019, 26, 6412-6437. [CrossRef] [PubMed]

16. Burris, H.A.; Bakewell, S.; Bendell, J.C.; Infante, J.; Jones, S.F.; Spigel, D.R.; Weiss, G.J.; Ramanathan, R.K.; Ogden, A.; Von Hoff, D. Safety and activity of IT-139, a ruthenium-based compound, in patients with advanced solid tumours: A first-in-human, open-label, dose-escalation phase I study with expansion cohort. ESMO Open 2016, 1, e000154. [CrossRef] [PubMed]

17. Melchart, M.; Sadler, P.J. Ruthenium Arene Anticancer Complexes. In Bioorganometallics; Wiley: Hoboken, NJ, USA, 2005; pp. 39-64. [CrossRef]

18. Bononi, G.; Iacopini, D.; Cicio, G.; Di Pietro, S.; Granchi, C.; Di Bussolo, V.; Minutolo, F. Glycoconjugated Metal Complexes as Cancer Diagnostic and Therapeutic Agents. ChemMedChem 2020, 16, 30-64. [CrossRef]

19. Habtemariam, A.; Melchart, M.; Fernandez, R.; Parsons, S.; Oswald, I.D.; Parkin, A.; Fabbiani, F.P.; Davidson, J.E.; Dawson, A.; Aird, R.E.; et al. Structure-activity relationships for cytotoxic ruthenium(II) arene complexes containing N,N-, N,O-, and O,O-chelating ligands. J. Med. Chem. 2006, 49, 6858-6868. [CrossRef]

20. Hartinger, C.G.; Nazarov, A.A.; Ashraf, S.M.; Dyson, P.J.; Keppler, B.K. Carbohydrate-Metal Complexes and their Potential as Anticancer Agents. Curr. Med. Chem. 2008, 15, 2574-2591. [CrossRef]

21. Böge, M.; Fowelin, C.; Bednarski, P.; Heck, J. Diaminohexopyranosides as Ligands in Half-Sandwich Ruthenium(II), Rhodium(III), and Iridium(III) Complexes. Organometallics 2015, 34, 1507-1521. [CrossRef]

22. Hamala, V.; Martišová, A.; Červenková Št'astná, L.; Karban, J.; Dančo, A.; Šimarek, A.; Lamač, M.; Horáček, M.; Kolářová, T.; Hrstka, R.; et al. Ruthenium tetrazene complexes bearing glucose moieties on their periphery: Synthesis, characterization, and in vitro cytotoxicity. App. Organomet. Chem. 2020, 34, e5896. [CrossRef]

23. Florindo, P.; Marques, I.J.; Nunes, C.D.; Fernandes, A.C. Synthesis, characterization and cytotoxicity of cyclopentadienyl ruthenium(II) complexes containing carbohydrate-derived ligands. J. Organomet. Chem. 2014, 760, 240-247. [CrossRef]

24. Florindo, P.R.; Pereira, D.M.; Borralho, P.M.; Rodrigues, C.M.P.; Piedade, M.F.M.; Fernandes, A.C. Cyclopentadienyl-Ruthenium(II) and Iron(II) Organometallic Compounds with Carbohydrate Derivative Ligands as Good Colorectal Anticancer Agents. J. Med. Chem. 2015, 58, 4339-4347. [CrossRef]

25. Florindo, P.R.; Pereira, D.M.; Borralho, P.M.; Costa, P.J.; Piedade, M.F.M.; Rodrigues, C.M.P.; Fernandes, A.C. New [( $\left.\eta^{5}-\mathrm{C}_{5} \mathrm{H}_{5}\right) \mathrm{Ru}(\mathrm{N}-$ $\left.\mathrm{N})\left(\mathrm{PPh}_{3}\right)\right]\left[\mathrm{PF}_{6}\right]$ compounds: Colon anticancer activity and GLUT-mediated cellular uptake of carbohydrate-appended complexes. Dalton Trans. 2016, 45, 11926-11930. [CrossRef]

26. Rostovtsev, V.V.; Green, L.G.; Fokin, V.V.; Sharpless, K.B. A Stepwise Huisgen Cycloaddition Process: Copper(I)-Catalyzed Regioselective "Ligation" of Azides and Terminal Alkynes. Angew. Chem. 2002, 41, 2596-2599. [CrossRef]

27. Meldal, M.; Tornoe, C.W. Cu-catalyzed azide-alkyne cycloaddition. Chem. Rev. 2008, 108, 2952-3015. [CrossRef]

28. Paulsen, H.; Györgydeák, Z.; Friedmann, M. Exo-Anomerer Effekt und Circulardichroismus von Glycopyranosylaziden. Chem. Ber. 1974, 107, 1568-1578. [CrossRef]

29. Györgydeák, Z.; Thiem, J. Synthesis and transformation of glycosyl azides. Adv. Carbohydr. Chem. Biochem. 2006, 60, 103-182. [CrossRef] [PubMed]

30. Gonda, Z.; Novák, Z. Highly active copper-catalysts for azide-alkyne cycloaddition. Dalton Trans. 2010, 39, 726-729. [CrossRef] [PubMed]

31. Bokor, É.; Koppány, C.; Gonda, Z.; Novák, Z.; Somsák, L. Evaluation of bis-triphenylphosphano-copper(I)-butyrate $\left(\mathrm{C}_{3} \mathrm{H}_{7} \mathrm{COOCu}\left(\mathrm{PPh}_{3}\right)_{2}\right)$ as catalyst for the synthesis of 1-(D-glycopyranosyl)-4-substituted-1,2,3-triazoles. Carbohydr. Res. 2012, 351, 42-48. [CrossRef] [PubMed]

32. Tóth, M.; Kun, S.; Bokor, É.; Benltifa, M.; Tallec, G.; Vidal, S.; Docsa, T.; Gergely, P.; Somsák, L.; Praly, J.-P. Synthesis and structure-activity relationships of $C$-glycosylated oxadiazoles as inhibitors of glycogen phosphorylase. Bioorg. Med. Chem. 2009, 17, 4773-4785. [CrossRef] [PubMed]

33. Viana, R.M.R.; Prado, M.A.F.; Alves, R.J. Synthesis and modifications of heterocyclic derivatives of D-arabinose: Potential inhibitors of glucose-6-phosphate isomerase and glucosamine-6-phosphate synthase. Quim. Nova 2008, 31, 1710-1713. [CrossRef]

34. Tawfiq, K.M.; Miller, G.J.; Al-Jeboori, M.J.; Fennell, P.S.; Coles, S.J.; Tizzard, G.J.; Wilson, C.; Potgieter, H. Comparison of the structural motifs and packing arrangements of six novel derivatives and one polymorph of 2-(1-phenyl-1H-1,2,3-triazol-4yl)pyridine. Acta Crystallogr. Sect. B Struct. Sci. Cryst. Eng. Mater. 2014, 70, 379-389. [CrossRef]

35. Wei, F.X.; Fang, L.; Huang, Y. Synthesis, characterization, crystal structures, and photophysical properties of a series of roomtemperature phosphorescent copper(I) complexes with oxadiazole-derived diimine ligand. Inorg. Chim. Acta 2010, 363, $2600-2605$. [CrossRef]

36. Weiss, V.C.; Farias, G.; Amorim, A.L.; Xavier, F.R.; Camargo, T.P.; Bregalda, M.B.; Haukka, M.; Nordlander, E.; de Souza, B.; Peralta, R.A. Luminescent PhotoCORMs: Enabling/Disabling CO Delivery upon Blue Light Irradiation. Inorg. Chem. 2020, 59, 13078-13090. [CrossRef] [PubMed]

37. Bai, P.; Bakondi, É.; Szabó, E.; Gergely, P.; Szabó, C.; Virág, L. Partial protection by poly(ADP-ribose) polymerase inhibitors from nitroxyl-induced cytotoxity in thymocytes. Free Radic. Biol. Med. 2001, 31, 1616-1623. [CrossRef]

38. Virág, L.; Scott, G.S.; Cuzzocrea, S.; Marmer, D.; Salzman, A.L.; Szabó, C. Peroxynitrite-induced thymocyte apoptosis: The role of caspases and poly (ADP-ribose) synthetase (PARS) activation. Immunology 1998, 94, 345-355. [CrossRef] [PubMed] 
39. Virág, L.; Salzman, A.L.; Szabó, C. Poly(ADP-ribose) synthetase activation mediates mitochondrial injury during oxidant-induced cell death. J. Immunol. 1998, 161, 3753-3759.

40. Gesztelyi, R.; Zsuga, J.; Kemény-Beke, A.; Varga, B.; Juhász, B.; Tosaki, A. The Hill equation and the origin of quantitative pharmacology. Arch. Hist. Exact. Sci. 2012, 66, 427-438. [CrossRef]

41. Xu, Z.; Kong, D.; He, X.; Guo, L.; Ge, X.; Liu, X.; Zhang, H.; Li, J.; Yang, Y.; Liu, Z. Mitochondria-targeted half-sandwich rutheniumII diimine complexes: Anticancer and antimetastasis via ROS-mediated signalling. Inorg. Chem. Front. 2018, 5, 2100-2105. [CrossRef]

42. Bakewell, S.; Conde, I.; Fallah, Y.; McCoy, M.; Jin, L.; Shajahan-Haq, A.N. Inhibition of DNA Repair Pathways and Induction of ROS Are Potential Mechanisms of Action of the Small Molecule Inhibitor BOLD-100 in Breast Cancer. Cancers 2020, $12,2647$. [CrossRef]

43. Parveen, S.; Hanif, M.; Leung, E.; Tong, K.K.H.; Yang, A.; Astin, J.; De Zoysa, G.H.; Steel, T.R.; Goodman, D.; Movassaghi, S.; et al. Anticancer organorhodium and -iridium complexes with low toxicity in vivo but high potency in vitro: DNA damage, reactive oxygen species formation, and haemolytic activity. Chem. Commun. 2019, 55, 12016-12019. [CrossRef] [PubMed]

44. Spillane, C.B.; Dabo, M.N.; Fletcher, N.C.; Morgan, J.L.; Keene, F.R.; Haq, I.; Buurma, N.J. The dichotomy in the DNA-binding behaviour of ruthenium(II) complexes bearing benzoxazole and benzothiazole groups. J. Inorg. Biochem. 2008, 102, 673-683. [CrossRef]

45. Hegedûs, C.; Juhász, T.; Fidrus, E.; Janka, E.A.; Juhász, G.; Boros, G.; Paragh, G.; Uray, K.; Emri, G.; Remenyik, É.; et al. Cyclobutane pyrimidine dimers from UVB exposure induce a hypermetabolic state in keratinocytes via mitochondrial oxidative stress. Redox Biol. 2021, 38, 101808. [CrossRef] [PubMed]

46. Sári, Z.; Mikó, E.; Kovács, T.; Boratkó, A.; Ujlaki, G.; Jankó, L.; Kiss, B.; Uray, K.; Bai, P. Indoxylsulfate, a Metabolite of the Microbiome, Has Cytostatic Effects in Breast Cancer via Activation of AHR and PXR Receptors and Induction of Oxidative Stress. Cancers 2020, 12, 2915. [CrossRef] [PubMed]

47. Bai, P. Biology of Poly(ADP-Ribose) Polymerases: The Factotums of Cell Maintenance. Mol. Cell 2015, 58, 947-958. [CrossRef] [PubMed]

48. Curtin, N.J.; Szabó, C. Poly(ADP-ribose) polymerase inhibition: Past, present and future. Nat. Rev. Drug Discov. 2020, 19, 711-736. [CrossRef] [PubMed]

49. De Camargo, M.S.; De Grandis, R.A.; da Silva, M.M.; da Silva, P.B.; Santoni, M.M.; Eismann, C.E.; Menegario, A.A.; Cominetti, M.R.; Zanelli, C.F.; Pavan, F.R.; et al. Determination of in vitro absorption in Caco-2 monolayers of anticancer Ru(II)-based complexes acting as dual human topoisomerase and PARP inhibitors. Biometals 2019, 32, 89-100. [CrossRef]

50. Yusoh, N.A.; Ahmad, H.; Gill, M.R. Combining PARP Inhibition with Platinum, Ruthenium or Gold Complexes for Cancer Therapy. ChemMedChem 2020, 15, 2121-2135. [CrossRef]

51. Zanjirband, M.; Curtin, N.; Edmondson, R.J.; Lunec, J. Combination treatment with rucaparib (Rubraca) and MDM2 inhibitors, Nutlin-3 and RG7388, has synergistic and dose reduction potential in ovarian cancer. Oncotarget 2017, 8, 69779-69796. [CrossRef]

52. Hanif, M.; Meier, S.; Nazarov, A.; Risse, J.; Legin, A.; Casini, A.; Jakupec, M.; Keppler, B.; Hartinger, C. Influence of the $\pi-$ coordinated arene on the anticancer activity of ruthenium(II) carbohydrate organometallic complexes. Front. Chem. 2013, 1, 27. [CrossRef]

53. Berger, I.; Hanif, M.; Nazarov, A.A.; Hartinger, C.G.; John, R.O.; Kuznetsov, M.L.; Groessl, M.; Schmitt, F.; Zava, O.; Biba, F.; et al. In Vitro Anticancer Activity and Biologically Relevant Metabolization of Organometallic Ruthenium Complexes with Carbohydrate-Based Ligands. Chem. Eur. J. 2008, 14, 9046-9057. [CrossRef] [PubMed]

54. Kiss, B.; Mikó, E.; Sebő, É.; Tóth, J.; Ujlaki, G.; Szabó, J.; Uray, K.; Bai, P.; Árkosy, P. Oncobiosis and Microbial Metabolite Signaling in Pancreatic Adenocarcinoma. Cancers 2020, 12, 1068. [CrossRef]

55. Sipos, A.; Ujlaki, G.; Mikó, E.; Maka, E.; Szabó, J.; Uray, K.; Krasznai, Z.; Bai, P. The role of the microbiome in ovarian cancer: Mechanistic insights into oncobiosis and to bacterial metabolite signaling. Mol. Med. 2021, 27, 33. [CrossRef] [PubMed]

56. Tykocki, T.; Eltayeb, M. Ten-year survival in glioblastoma. A systematic review. J. Clin. Neurosci. 2018, 54, 7-13. [CrossRef] [PubMed]

57. Smolková, K.; Mikó, E.; Kovács, T.; Leguina-Ruzzi, A.; Sipos, A.; Bai, P. NRF2 in regulating cancer metabolism. Antioxid. Redox Signal. 2020, 33, 966-997. [CrossRef]

58. Hadady, Z.; Tóth, M.; Somsák, L. C-( $\beta$-D-glucopyranosyl) heterocycles as potential glycogen phosphorylase inhibitors. Arkivoc 2004, 7, 140-149. [CrossRef]

59. Kun, S.; Nagy, G.Z.; Tóth, M.; Czecze, L.; Nguyen van Nhien, A.; Docsa, T.; Gergely, P.; Charavgi, M.-D.; Skourti, P.V.; Chrysina, E.D.; et al. Synthesis of variously coupled conjugates of D-glucose, 1,3,4-oxadiazole, and 1,2,3-triazole for inhibition of glycogen phosphorylase. Carbohydr. Res. 2011, 346, 1427-1438. [CrossRef]

60. Somsák, L.; Bokor, É.; Czibere, B.; Czifrák, K.; Koppány, C.; Kulcsár, L.; Kun, S.; Szilágyi, E.; Tóth, M.; Docsa, T.; et al. Synthesis of C-Xylopyranosyl- and Xylopyranosylidene-Spiro-Heterocycles for Inhibition of Glycogen Phosphorylase. Carbohydr. Res. 2014, 399, 38-48. [CrossRef] [PubMed]

61. Farkas, I.; Szabó, I.F.; Bognár, R. Conversion of acetylated glycosyl cyanides into C-glycosyl derivatives of benzothiazole and tetrazole. Carbohydr. Res. 1977, 56, 404-406. [CrossRef] 
62. Son, M.H.; Kim, J.Y.; Lim, E.J.; Baek, D.J.; Choi, K.; Lee, J.K.; Pae, A.N.; Min, S.J.; Cho, Y.S. Synthesis and biological evaluation of 2-(arylethynyl)quinoline derivatives as mGluR5 antagonists for the treatment of neuropathic pain. Bioorg. Med. Chem. Lett. 2013, 23, 1472-1476. [CrossRef]

63. Wilkinson, B.L.; Bornaghi, L.F.; Poulsen, S.A.; Houston, T.A. Synthetic utility of glycosyl triazoles in carbohydrate chemistry. Tetrahedron 2006, 62, 8115-8125. [CrossRef]

64. Kraft, J.; Schmollinger, D.; Maudrich, J.; Ziegler, T. Synthesis of Sugar-Derived Triazole-and Pyridine-Based Metal Complex Ligands. Synthesis 2015, 47, 199-208. [CrossRef]

65. Shen, C.; Zheng, H.; Zhang, P.F.; Chen, X.Z. Synthesis of Some Novel Glucosyl Triazoles from 2,3,4,6-Tetra-O-pivaloyl-Dglucopyranosyl Azide. J. Carbohydr. Chem. 2010, 29, 155-163. [CrossRef]

66. Kozsup, M.; Dömötör, O.; Nagy, S.; Farkas, E.; Enyedy, É.A.; Buglyó, P. Synthesis, characterization and albumin binding capabilities of quinizarin containing ternary cobalt(III) complexes. J. Inorg. Biochem. 2020, 204. [CrossRef]

67. Bakondi, E.; Gönczi, M.; Szabó, É.; Bai, P.; Pacher, P.; Gergely, P.; Kovács, L.; Hunyadi, J.; Szabó, C.; Csernoch, L.; et al. Role of intracellular calcium mobilization and cell-density-dependent signaling in oxidative-stress-induced cytotoxicity in HaCaT keratinocytes. J. Invest. Dermatol. 2003, 121, 88-95. [CrossRef] [PubMed]

68. Fodor, T.; Szantó, M.; Abdul-Rahman, O.; Nagy, L.; Der, A.; Kiss, B.; Bai, P. Combined Treatment of MCF-7 Cells with AICAR and Methotrexate, Arrests Cell Cycle and Reverses Warburg Metabolism through AMP-Activated Protein Kinase (AMPK) and FOXO1. PLoS ONE 2016, 11, e0150232. [CrossRef]

69. Virág, L.; Marmer, D.J.; Szabó, C. Crucial role of apopain in the peroxynitrite-induced apoptotic DNA fragmentation. Free Radic. Biol. Med. 1998, 25, 1075-1082. [CrossRef]

70. Márton, J.; Fodor, T.; Nagy, L.; Vida, A.; Kis, G.; Brunyánszki, A.; Antal, M.; Lüscher, B.; Bai, P. PARP10 (ARTD10) modulates mitochondrial function. PLoS ONE 2018, 13, e0187789. [CrossRef]

71. Box, G.E.P.; Cox, D.R. An analysis of transformations. J. R. Stat. Soc. B 1964, 26, 211-234. [CrossRef] 